\title{
Salmonid Response to Habitat Restoration in a High-Elevation West Virginia Watershed
}

\author{
Cory T. Trego
}

Follow this and additional works at: https://researchrepository.wvu.edu/etd

\section{Recommended Citation}

Trego, Cory T., "Salmonid Response to Habitat Restoration in a High-Elevation West Virginia Watershed" (2017). Graduate Theses, Dissertations, and Problem Reports. 6829.

https://researchrepository.wvu.edu/etd/6829

This Thesis is protected by copyright and/or related rights. It has been brought to you by the The Research Repository @ WVU with permission from the rights-holder(s). You are free to use this Thesis in any way that is permitted by the copyright and related rights legislation that applies to your use. For other uses you must obtain permission from the rights-holder(s) directly, unless additional rights are indicated by a Creative Commons license in the record and/ or on the work itself. This Thesis has been accepted for inclusion in WVU Graduate Theses, Dissertations, and Problem Reports collection by an authorized administrator of The Research Repository @ WVU. For more information, please contact researchrepository@mail.wvu.edu. 


\title{
Salmonid response to habitat restoration in a high-elevation West Virginia watershed
}

\author{
Cory T. Trego
}

\begin{abstract}
A Thesis submitted to
The Davis College of Agriculture, Natural Resources, and Design at West Virginia University
\end{abstract}

in partial fulfilment of the requirements for the degree of

Master of Science in

Wildlife and Fisheries Resources

J. Todd Petty, Ph.D., Chair

Stuart A. Welsh, Ph.D.

Eric R. Merriam, Ph.D.

Department and Wildlife and Fisheries Resources

Morgantown, WV

2017

Keywords: Brook trout; stream restoration; Upper Shavers Fork; headwater streams; stream ecology; population dynamics; habitat use; competition; exotic species

Copyright 2017 Cory Trego 


\title{
ABSTRACT \\ Salmonid response to habitat restoration in a high-elevation West Virginia watershed
}

\author{
Cory Trego
}

Brook trout Salvelinus fontinalis have experienced significant population declines throughout much of their native range, largely due to habitat loss. Increasing effort has been put toward restoring and preserving existing brook trout habitat in the face of continued loss under uncertain future conditions (e.g., climate change). We conducted a study designed to analyze both macroscale (i.e. at channel unit level) and microscale (i.e. within individual pools) habitat use in the context of stream restoration by brook trout and two competing nonnative salmonid species: brown trout Salmo trutta and rainbow trout Oncorhynchus mykiss. First we conducted a beforeafter-control-impact assessment of a multi-scale restoration project designed to improve brook trout habitat on the Shavers Fork, West Virginia by comparing trout use of habitat at the channel unit scale one year before and one and three years after restoration. We then used snorkeling surveys to assess and compare microhabitat preferences of brook, brown, and rainbow trout in constructed and natural pool habitats in Shavers Fork. Our over-riding objective of this project was to assess the response of brook trout and competing nonnative salmonids to habitat restoration in the Shavers Fork of the Cheat River, West Virginia at both the hydraulic channel unit scale and the microhabitat scale within individual pools. Channel unit shifts after habitat restoration suggests that restoration had significant impacts on macroscale habitat selection by these three trout species and that brown trout may be excluding brook trout from preferred reaches. Underwater observation of trout indicated that species occupied distinct microhabitats, but subsequent analysis revealed that much of the variation in habitat selection can be explained by estimated trout length. Brook trout occupying pools sympatrically with brown and rainbow trout occupied significantly different microhabitats than brook trout occupying pools allopatrically, suggesting competition between brook trout and nonnative salmonids is significantly influencing brook trout behavior and habitat selection. Future studies should consider removal of nonnative salmonids to determine habitat use and population trends in their absence from stream reaches. 


\section{Acknowledgements}

I would like to thank my committee for their consistent support and assistance throughout my time at West Virginia University, Dr. J. Todd Petty for his insight into salmonid population dynamics and play in the Upper Shavers Fork Watershed that led to the development of this project, and Dr. Eric Merriam for providing me with valuable edits to the various drafts of this document. I would also like to thank Dr. Chris Rota for his assistance in answering questions about statistical analyses. Additionally, I would like to thank Dr. Michelle Briggs, Dr. Mel Zimmerman, and Dr. David Broussard of Lycoming College for fostering my love for the ecological sciences.

I would also like to thank my parents and grandparents for always inspiring me to ask questions and seek answers about the natural world. Your support has always pushed me to pursue my dreams. I could have no better examples of how to life a life rooted in faith and love. Finally, I would like to thank my wife for her steadfast love, support, and encouragement. There is no one else with whom I would rather navigate through life. 


\section{Table of Contents}

Chapter 1: A review of the literature on brook trout ecology, current population drivers, habitat restoration efforts, and underwater observation surveys ............................................1

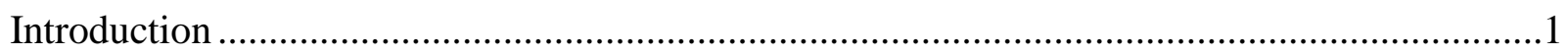

Anthropogenic Controls over Brook Trout Habitat and Populations ............................... 3

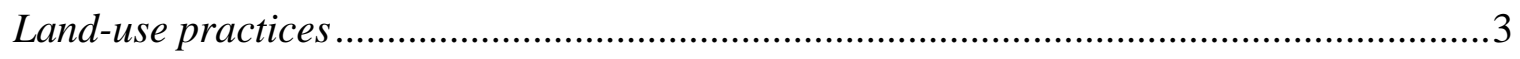

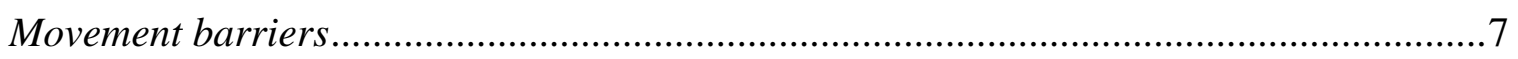

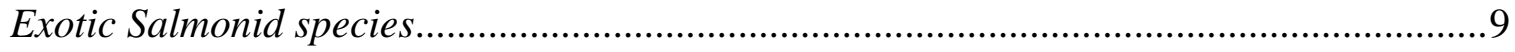

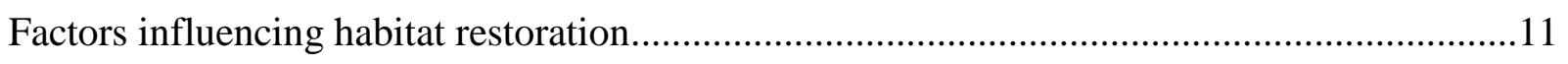

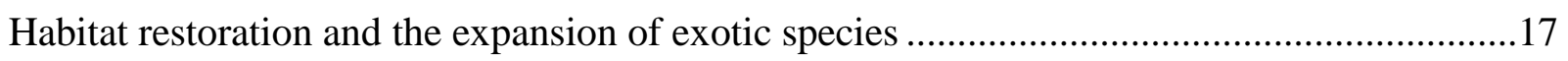

Assemblage organizations and habitat selection in freshwater ecosystems ..........................20

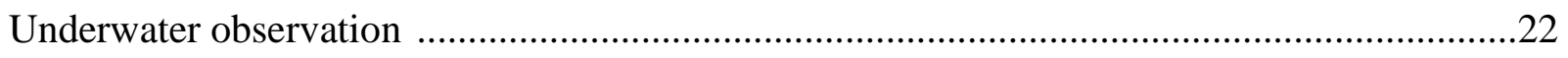

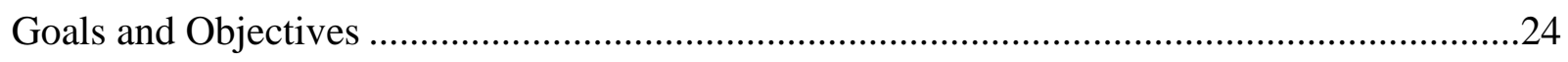

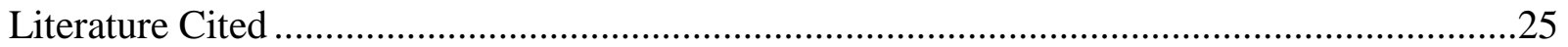

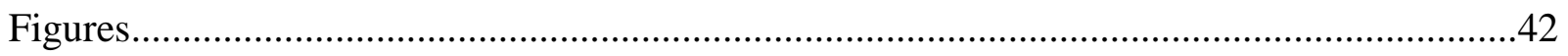

Chapter 2: Temporal evaluation of salmonid habitat use before and after a multi-scale

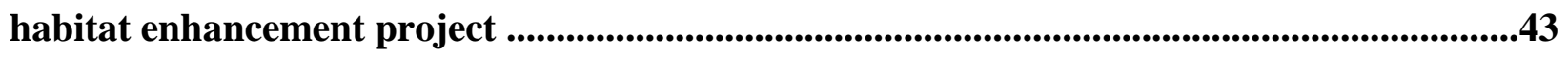

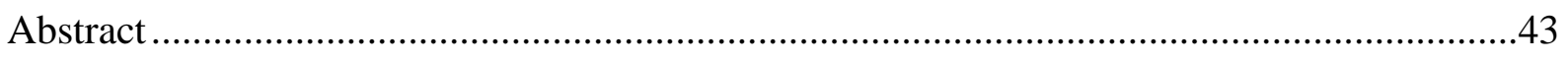

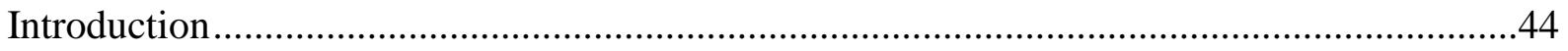

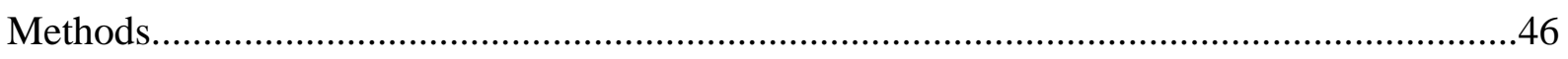

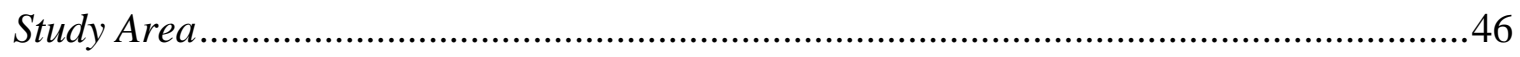

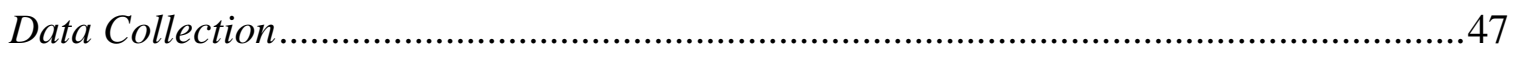

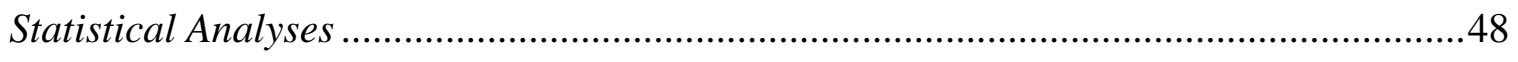

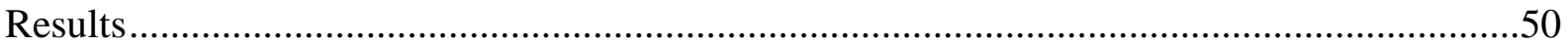

Habitat Parameter Changes at the Habitat Channel Unit scale .....................................50

Distributional Shifts at the Channel Unit Scale ...............................................................51

Characteristics Influencing Trout Distribution .......................................................52

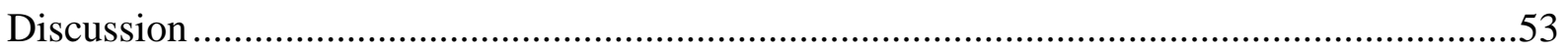




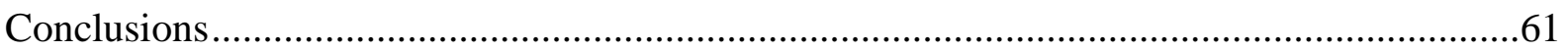

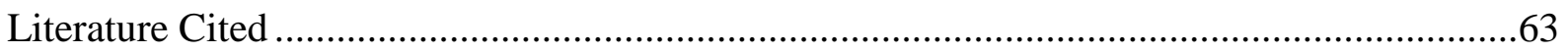

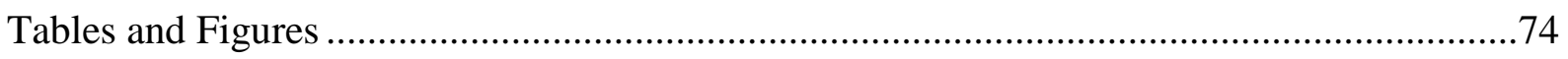

Chapter 3: Microhabitat use by brook, brown, and rainbow trout in a restored highelevation Appalachian stream........................................................................................................................85

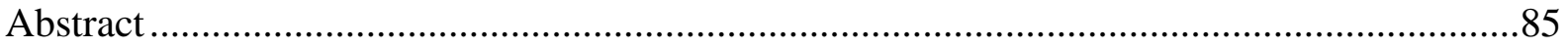

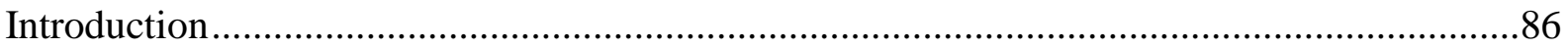

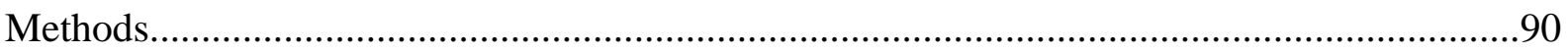

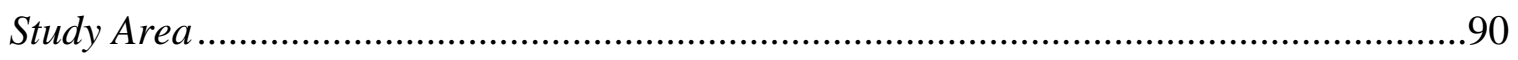

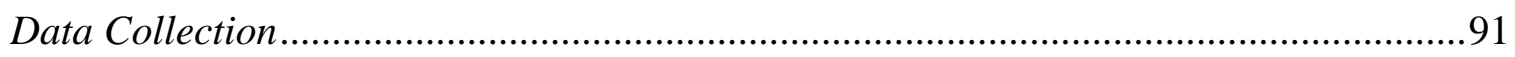

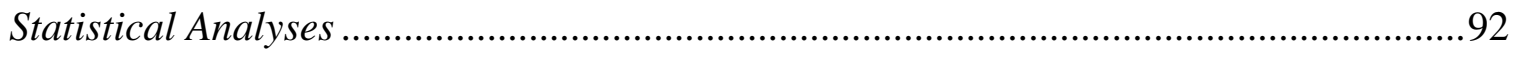

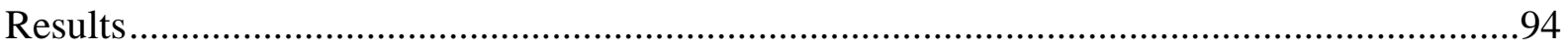

Microhabitat use by brook, brown, and rainbow trout...............................................94

Relationships between length and habitat selection ...................................................96

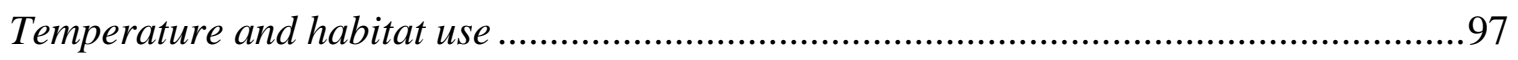

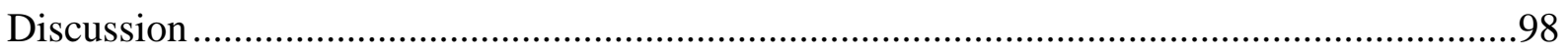

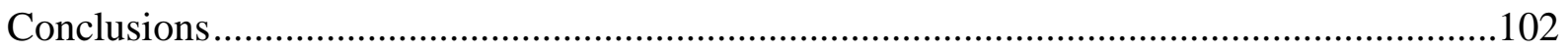

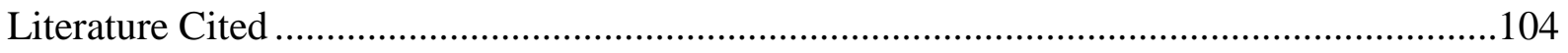

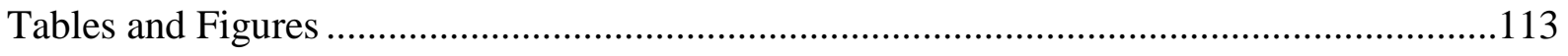




\section{Chapter 1: A review of the literature on brook trout ecology, current population drivers, habitat restoration efforts, and underwater observation surveys}

\section{Introduction}

Brook trout (Salvelinus fontinalis) are the only trout species native to the headwaters of the Appalachian Mountains in the eastern United States. Over the past century, brook trout populations have significantly declined across much of their original range as a result of habitat loss, overfishing, and competition from non-native salmonids (Marshall and Crowder 1996, Petty and Merriam 2012). Both conservation and restoration efforts are needed to ensure long-term population stability.

Brook trout populations have declined significantly across their range in the eastern United States. Hudy et al. (2008) quantified the current distribution and status of brook trout across their native range at the subwatershed level. They determined that only $31 \%$ of subwatersheds surveyed have intact brook trout habitats ( $>50 \%), 35 \%$ of subwatersheds have reduced habitat $(<50 \%)$, and $28 \%$ contained habitat from which brook trout were extirpated. Further analysis using multiple spatial scales revealed that brook trout occupancy declined from $52 \%$ at the watershed (10-digit HUC) scale to $32 \%$ at the subwatershed (12-digit HUC) and further to and $14 \%$ at the catchment-level scale (14-digit HUC). Extirpation rates are greatest in the southern extent of their range, where brook trout have vanished from more than $40 \%$ of their original subwatersheds (Figure 1). In West Virginia, brook trout have been extirpated from 25\% of their historical range, and exist today as reduced and highly fragmented populations in $85 \%$ of their current range (Hudy et al. 2005).

Severe habitat loss was the primary driver of initial population declines. Widespread anthropogenic alterations to landscapes began during the logging era, when significant loads of 
sediment and widespread loss of shading riparian vegetation diminished brook trout populations across much of their range (MacCrimmon and Campbell 1969). Since this initial population and habitat loss, the introduction of rainbow trout (Onchorhyncus mykiss) and brown trout (Salmo trutta) into streams across much of the brook trout's traditional range has resulted in significant competition for habitat and feeding sites and increased rates of predation on younger brook trout (Fausch and White 1981; Marshall and Crowder 1996; McKenna et al. 2013). Acid deposition, increased development and deforestation, and increasing temperature variability continue to threaten brook trout populations (Marschall and Crowder 1996; McClurg et al. 2007; Hudy et al. 2008; Xu et al. 2010).

In the past few decades there has been a resurgence of interest in native species conservation (Ahn et al. 2000; Petty et al. 2005). A report by the Eastern Brook Trout Joint Venture noted that if populations continue to decline, a traditional brook trout fishery could cease to exist (EBTJV 2008). The decline of native brook trout has deprived areas throughout the Appalachians of significant recreational, economic, and aesthetic benefits (Ahn et al. 2000). With continued threats arising from climate change and constant landscape alterations, it is imperative to develop a greater understanding of all factors that influence the success of habitat restoration efforts to effectively restore populations across their range.

Traditional efforts designed to improve brook trout populations include stocking and instream habitat modification (Flebbe 1999); however, in recent years, restoring favorable brook trout habitat has been preferred over stocking because of its long-term benefits on native populations. Habitat restoration projects typically aim to alter the stream environment to slow the loss of biodiversity by improving water quality, aquatic habitat, and fostering fish population growth (Larson et al. 2001; Lepori et al. 2005; McClurg et al. 2007). However, habitat 
restoration projects designed to improve conditions for native brook trout could unintentionally confer greater benefits to exotic species than to the intended species. Thus, it is imperative to understand the response of both target and non-target species in the years following restoration projects and to define habitat preferences of each species so projects can be designed to maximize benefits to target species.

The following chapter offers a broad review of the literature on brook trout ecology and potential factors critical to restoring brook trout populations across the eastern United States. This review begins with an overview of the influences anthropogenic controls on brook trout populations. Then potential factors influencing the success of restoration projects are discussed, followed by an overview of mechanisms for exotic species expansion facilitated by restoration projects. Physical and biological effects on fish assemblage organization, factors influencing micro-habitat selection, and characteristics of social dominance hierarchies are then briefly covered. Finally, an overview of underwater observation techniques and considerations is presented

\section{Anthropogenic Controls over Brook Trout Habitat and Populations}

\section{Land-use practices}

The chemical, physical, and biological integrity of streams depend heavily on the characteristics of the surrounding landscape. Landscape features profoundly impact environmental stability within streams (Richards et al. 1996; Fausch et al. 2002; Allan 2004). Environmental stability has a large bearing on the species diversity a stream can support and impacts broader salmonid metapopulation structure (Dunham and Rieman 1999; Neville et al. 2006). Structurally diverse streams are more resistant to significant environmental changes 
(Gorman and Karr 1978) and habitat heterogeneity is needed for species diversity (Freeman and Grossman 1998). Land-use practices over the past century have led to environmental destabilization and impairment in many headwater streams, reducing habitat availability for coldwater species, such as brook trout.

Large-scale timber harvest operations throughout the 1900's led to the first major anthropogenic alterations to headwater streams. Timbering operations throughout the Appalachians led to substantial sedimentation, loss of riparian vegetation, channel modification, and the loss of large woody debris, leading to severe habitat degradation (Golladay and Webster 1988; Flebbe and Dolloff 1995; Marshall and Crowder 1996; Nilsson et al. 2005). Early losses in brook trout distribution are often attributed to these initial harvesting operations (MacCrimmon and Campbell 1969). Streams used for floating harvested timber experienced reduced pool-riffle variability and greater shear stress, leading to higher rates of erosion and greater sediment transport (Nilsson et al 2005). This loss of riffle-pool variability reduced access to thermal refugia (Petty et al 2012), reduced invertebrate densities (Angermeier and Schlosser 1989), and reduced general habitat complexity (Gustafsson et al. 2013). Habitat heterogeneity and complexity is correlated to higher species diversity (Grossman et al. 2008), reduces resource limitations (Grossman et al. 1998), and creates more in-stream stability (Swanson et al 1999). This stability reduces the possibility of niche overlap and slows changes in competitive advantages between species (Grossman et al. 1998), creating population stability over long periods of time. Channel modifications caused by poor land use practices still exclude brook trout populations from sufficiently recolonizing watersheds today, necessitating stream restoration within these reaches (Petty et al. 2012). 
Agriculture and urbanization are the two leading causes of brook trout habitat loss today. Total forested area, percent agriculture, and sediment deposition levels influence rates of brook trout occurrence, where higher total forested area is positively correlated with brook trout presence and greater agricultural land use and higher sediment deposition are negatively correlated with brook trout presence (Hudy et al. 2008; Stranko et al. 2008). Stranko et al. (2008) found that brook trout were consistently absent from watersheds that consisted of greater than 4\% impervious cover and were predicted to be absent from watersheds with greater than $3.3 \%$ impervious cover. Loss of forested habitat through timber harvest, agriculture conversion, and development continually facilitates increased sediment loads, increased stream temperatures, channel homogenization, and loss of large woody debris from the system (Allen 2004).

Sedimentation occurs due to faster drainage of runoff from the surrounding landscape, leading to scouring action, bank erosion, wider stream channels, and habitat homogeneity (Vietz et al. 2014), ultimately resulting in loss of both foraging and reproductive habitat. Salmonid redds are typically constructed at the riffle-pool transition (Bjornn and Reiser 1991; Cienciala and Hassan 2013). In degraded habitats, the absence of typical fine-grained reaches may force trout to spawn in small hydraulically sheltered areas, spurring increased competition for redd sites (Beschta and Platts 1986; Cienciala and Hassan 2013). Redd sites prepared in inferior locations are more vulnerable to scouring or sediment deposition, leading to increased embryo morality rates and population declines over time. Sedimentation can lead to further embryo mortality by stymying oxygen diffusion from the surrounding water (Sear et al. 2008; Cienciala and Hassan 2013).

Agricultural conversion and urbanization result in loss of riparian vegetation, leading to excessive thermal variation in small streams (Smith and Lavis 1975; Poole and Berman 2001). Wide and shallow stream channels are often slow moving, lack mature stream-side vegetation, 
and have long periods of solar exposure. Dark substrate compounds the influence of lack of shading vegetation on the warming of waterways (Smith and Lavis 1975). Thermal regimes are one of the greatest factors affecting brook trout presence or absence, with temperatures exceeding $20^{\circ} \mathrm{C}$ severely limiting brook trout growth and abundance (Hartman and Sweka 2001; Xu et al. 2010; Petty et al. 2012). Maximum growth for brook trout occurs between $10-12{ }^{\circ} \mathrm{C}$, and it is estimated that each $1.5{ }^{\circ} \mathrm{C}$ increase in temperature reduced brook fecundity by $18 \%$ (Xu et al. 2010). Hartman and Sweka (2001) noted that higher basal metabolic rates make brook trout growth impossible above $20{ }^{\circ} \mathrm{C}$. Land use must be closely monitored in streams where water temperatures rise above $21{ }^{\circ} \mathrm{C}$ in the summer months to prevent significant stress on brook trout populations.

Evidence suggests that global climate change will lead to continued warming trends throughout the Appalachians, further compounding the effects of agricultural and urbanization impairment (Allen et al. 2009). Increased global and regional temperatures are expected to result in higher water temperatures, earlier snowmelt, increased frequency of floods and droughts, low dissolved oxygen and higher sediment inputs, leading to significant changes within ecosystem structure (Wilby et al. 2010). Region-specific studies are needed to further understand the potential influence of climate change at the watershed scale. Because stream warming is influenced by numerous factors, landscape level restoration projects may be needed to effectively mitigate the impacts of temperature change.

\section{Movement Barriers}

Recent emphasis on metapopulation dynamics (Fagan 2002; Letcher et al. 2007; Petty et al. 2012; Huntsman and Petty 2014) has increased interest in barrier removal to facilitate the 
passage of economically important species, such as brook trout. The ability to disperse to find new habitats, escape poor environmental conditions, access spawning grounds, foster gene flow, and avoid resource competition is essential to brook trout survival (Petty et al. 2005; Anderson et al. 2010; Petty et al. 2012; Huntsman and Petty 2014). Brook trout movement and habitat selection have been documented in great detail over the past few decades. Adult brook trout display wide-ranging patterns in movement influenced by stream size, temperature, season, and competition, with some individuals moving several kilometers during a single season (Gowan and Faush 1996; Hartman and Logan 2010; Petty et al. 2012). Size and dominance may also influence movement patterns. Cumulative movement, home range, and daily movement are all negatively related to fish size, indicating that smaller fish may be forced out of optimal habitats by larger, more dominant individuals (Symons 1971; Nakano 1995).

Isolation of habitats is a significant driver of biodiversity and genetic diversity loss (Manel and Holdregger 2013). Physical (e.g., dams and culverts) and chemical (e.g., severe acid mine drainage) dispersal barriers are pervasive throughout the brook trout's native range (McClurg et al. 2007; Poplar-Jeffers et al. 2009). Culverts are commonly found along headwater streams in the mountainous regions of the eastern United States due to frequent stream crossings and their economic advantage over bridges, despite many acting as significant fish barriers (Gibson et al. 2005). Culverts constructed with significant overhang, low inlet or outlet depth, lack of streambed substrate within the culvert, and excessive slope (>3\%) are often impassible to most fish species, especially larger salmonids (Park et al. 2008; Love and Bates 2009). A significant portion of culverts within the Appalachians remain impassable or only partially passable to most fish species, isolating hundreds of kilometers of prime brook trout habitat, including a substantial amount of headwater spawning habitat (Poplar-Jeffers et al 2009; 
Anderson et al. 2012). Chemical impairment, such as severe acid mine drainage, render many stream miles uninhabitable throughout much of brook trout's native range, further reducing access to headwater streams and effectively severing gene flow in many watersheds (Petty et al. 2010). These widespread dispersal barriers significantly contribute to fish population declines. Decreased mobility results in lowered genetic diversity, changes in life history characteristics and demographic processes, and increased risk of extirpation (Letcher et al. 2007; Whiteley et al. 2013).

Habitat fragmentation severely reduces gene flow throughout metapopulations (Letcher et al. 2007). Salmonid habitats are naturally dynamic, yet anthropogenic activity has accelerated rates of change within these ecosystems during the past two centuries. Rapidly changing landscapes leave little time for species to adapt to new environmental conditions, leading to a greater likelihood of severe population declines or extinctions (Anderson et al. 2010). Gene flow between different populations is essential for long-term population survival in such a rapidly changing environment (Waples et al. 2009). Stream-fish genetics may be structured over a small area due to the limited ability of dispersal and reproductive dominance by a few large breeders, resulting in reduced ability to adapt to a range of potential environmental stressors (Hudy et al. 2010; Tatarenkov et al. 2010). Headwater streams throughout the Appalachians are particularly at risk due to single point of connectivity between upstream and downstream segments, and due to common dendritic stream patterns, which lead to lower levels of genetic diversity between watersheds (Spear et al. 2005). Complete blockage of gene flow in established metacommunities can lead to rapid extinction within isolated watersheds (Letcher 2007). Long-term isolation can also lead to phenotypic differences suited to site-specific environmental conditions. Brook trout in small tributaries isolated for hundreds of generation have been found to reproduce earlier and 
exhibit stunted growth, placing these sub-populations at greater risk for extinction (Letcher et al. 2007).

Increased movement during summer months suggests that it is a critical life history strategy to relocate to cooler stream segments (Petty et al. 2012; Aunins et al. 2015). In larger fluvial systems, summer stream temperatures often exceed the optimal temperature range for brook trout (Sweka and Hartman 2006, Xu et al. 2008). Summer thermal stress is expected to increase under numerous climate models (Wenger et al. 2011; Warren et al. 2012).

Interconnectedness between large, productive fluvial systems and smaller, cold tributaries provides brook trout with additional thermal refuges during periods of elevated temperatures. These connections can also alleviate density dependence within headwater streams, as larger, more dominant brook trout can disperse into main stem habitat and occupy thermal refugia to increase growth potential (Petty et al. 2014), and provided access to small headwater streams

(catchment areas $<3 \mathrm{~km}^{2}$ ) optimal for brook trout spawning. Blocking access to these small headwater streams could result in decreased spawning activitiy and long-term population declines.

\section{Exotic salmonid species}

Numerous studies have focused on interactions between brook trout and other salmonid species (Butryn et al. 2013; Magoulick and Wilzbach 1998; Ohlund et al. 2008). In streams with brook, brown, and rainbow trout, brook trout are typically the dominant species in the headwaters, while rainbow and brown trout are more abundant downstream (Magoulick and Wilzbach 1998; Anglin and Grossman 2013). Brook trout appear to have a competitive advantage in coldwater steams when compared to rainbow and brown trout and exhibit higher 
juvenile growth rates and earlier reproduction in cold headwater streams than brown trout (Ohlund et al. 2008), likely due to the ability to out-perform non-native salmonids for resources in cooler stream temperatures.

Habitat preferences and requirements also influence the success and distribution of salmonids within stream systems. While brown trout are typically more dominant than other salmonids, the availability of large pools influences their successful colonization of a stream (Oglund et al. 2008). Brown trout shift population preferences over their life history. Juveniles typically live in shallow riffle areas, while larger individuals occupy the backs of deeper pools. Brown trout are much larger at sexual maturity than brook trout. Large pools are needed to support sexually mature individuals; a lack of these aquatic environments limits the number of mature breeding fish in a stream. Shortages of larger, deep pools may limit an entire population and may lead to few breeding females for recruitment (Oglund et al. 2008). Because recruitment is directly related to the number of breeding adults (Post et al. 1998), small streams without large pool habitats will not be able to support an abundant brown trout population. Female brook trout occupy a more diverse arrangement of habitats as compared to female brown trout, and since they reach sexual maturity at a smaller size than brown trout, they are able to use a much greater variety of habitats available within small streams (Oglund et al. 2008).

In streams with naturally occurring brook trout populations, brook trout densities and overall probability of occurrence are often lower in areas when introduced trout species are present (Fausch and White 1981; Butryn et al. 2013; McKenna et al. 2013; Wagner et al. 2013). Studies have found that brook trout are less abundant in the presence of brown trout, but brown trout densities do not decline with the presence of brook trout, and in sympatric populations, brown trout densities are often higher than brook trout densities (Oglund et al. 2008). The 
mechanisms for this could include displacement from suitable habitat, predation on brook trout by brown trout (Fausch and White 1981), and variable susceptibility to angling pressure (Oglund et al. 2008).

Interspecific competition is environment specific; relationships between species shift between varying environmental conditions. For salmonids, temperature impacts competitive superiority between species (Magoulick and Wilzbach 1998; Taniguichi et al. 1998). Brook trout rapidly colonize small headwater streams when they are introduced into foreign systems because of their heightened competitive ability in cold water (Wenger et al. 2011; Warmock and Rasmussen 2013). Brown trout, however, typically reside in lower stream reaches and often replace brook trout populations within these reaches because of greater competitive ability and long-term survival in warmer stream conditions (Oglund et al. 2008; Butryn et al. 2013; McKenna et al 2013).

\section{Factors Influencing Habitat Restoration Efforts}

Stream channel restoration and structural habitat enhancement are often used to restore aquatic ecosystems (Bond and Lake 2003; Petty and Merriam 2012). The number of habitat restoration projects within the United States has grown significantly over the past few decades. Estimated average annual spending on restoration projects exceeds $\$ 1$ billion (Bernhardt et al. 2005). Physical habitat restoration attempts to create suitable habitat for target species within the stream channel. Typical restoration projects consist of installing woody debris, such as rootwads, along the banks of streams to stabilize the banks, creating pools, narrowing channels, increasing riparian vegetation and providing cover for fish species. Artificial structures, such as cross-veins and j-hooks, are often constructed of stone and are placed directly in the stream 
channel to moderate the stream's flow to narrow channels, create pools and riffles, and to reduce bank erosion (van Zyll de Jong et al. 1997).

Brook trout have been the focal species for a wide range of restoration efforts (Hartman and Sweka 2006: McClurg et al. 2007; Poplar-Jeffers et al 2009; Anderson et al. 2012). Past efforts at influencing brook trout populations include stocking and in-stream habitat modification (Flebbe 1999); however, recently restoring favorable brook trout habitat has been preferred over stocking because habitat modification projects are seen as long-term solutions to brook trout population decline. These projects typically aim to alter the stream environment to slow the loss of biodiversity by improving fish habitat and fostering fish population growth (Larson et al. 2001; Lepori et al. 2005). Restoration projects have aimed to increase available habitat through physical habitat restoration, such as the installation of woody debris (Hartman and Sweka 2006), the construction of cross veins (Van Zyll de Jong et al. 1997), or culvert remediation (PoplarJeffers 2009), and chemical remediation, such as treating stream for acid precipitation and acid mine drainage (McClurg et al. 2007). Many of these projects have successfully increased trout populations within the desired reaches (Van Zyll de Jong et al. 1997; Neumann and Wildman 2002).

In-stream habitat structures, such as cross veins, wood installation, and boulder clusters, are widely used as methods to narrow stream channel, provide in-stream cover, and create more pool habitat. Additions of large woody debris (LWD) into streams have become a popular method to expand suitable salmonid habitat and increase populations (Roni and Quinn 2001). Trout numbers are greater in pools with large woody debris and studies have found higher occupancy rates in restored reaches (Neumann and Wildman 2002; Hartman and Sweka 2006). Larger pieces of woody debris efficiently create pools and habitat suited for trout due to the 
production of scouring action. Flebbe (1999) found that brook trout favored pools with woody debris over pools without debris, yet favored all pool habitats over riffles. Numerous studies have demonstrated greater trout densities in reaches containing high densities of LWD (Flebbe and Dolloff 1995; Flebbe 1999; Neumann and Wildman 2002). Additions of LWD create greater habitat complexity, increase the storage of organic sediment, provide shelter for various life stages of fishes and increase the production of benthic marcoinvertebrates (Beschta and Platts 1986; Sullivan et al. 1987; Nakamura and Swanson 1993). Studies have found that adding LWD to stream systems can increase both brook trout and exotic trout populations (Neumann and Wildman 2002). Hartman and Sweka (2006) found that reaches with additions of LWD over a broad scale had greater young of the year (YOY) densities the following fall and spring, but densities returned to normal the next fall, indicating that density-dependent factors may have had a greater influence on long-term population dynamics. Van Zyllde Jong et al. (1997) noted that rock structures, such as j-hooks and boulder clusters, led to greater densities of both brook trout and juvenile Atlantic salmon Salmo salar as a result of increased habitat complexity and reduced competition for resources.

Increased habitat loss due to climate change poses a large threat to many coldwater fishes, and heightens the need for successful, comprehensive restoration projects. Brook trout are especially vulnerable to predicted climate change, with substantial population loss expected throughout much of their current range (Flebbe et al. 2006; Wenger et al. 2011). Thus, minimizing the impacts of rising global temperatures should be a priority during trout habitat restoration projects. Salmonids have been observed to seek out cold water refugia during warm stream conditions (Nielsen et al. 1994; Petty et al. 2012). Where large flows of cold water exist from tributaries and groundwater seepage, differences in density between warm and cold water 
can inhibit mixing, creating small, thermally stratified pools (Nielsen et al. 1994). Brook trout have been shown to move significantly to utilize thermal refugia during elevated summer water temperatures (Petty et al. 2005; Petty et al. 2012). Restoration efforts focused on creating thermal refugia may enable brook trout to occupy main stem reaches in fluvial systems, providing connectivity between tributaries and optimal conditions for maximized growth rates.

Significantly greater growth rates have been observed in the main stem and in small tributaries, likely because the main stem is significantly more productive than smaller headwater streams and offers more diversified prey. Brook trout in headwater streams are limited to consuming primarily aquatic and terrestrial invertebrates, while in the main stem the prey base is also composed of a variety of small fish (Petty et al. 2014). Evidence also suggests that access to main stem reaches in a fluvial system can also alleviate density-dependent regulation within tributaries (Huntsman and Petty 2014).

Restoration projects must be designed to accommodate seasonal changes in microhabitat use among brook trout (Anglin and Grossman 2013; Beechie et al. 2012; Petty et al. 2012). Physical properties of streams, such as temperature, velocity, depth, channel width, and available habitat, change significantly throughout the years, creating potential bottlenecks for population growth due to times of limited resources. Habitat use varies across life stages in most aquatic species (Angermeier and Schlosser 1989; Bond and Lake 2003; Schlosser 1982). For example, adult trout may utilize deeper thermal refugia during warm months or low flow periods (Petty et al. 2014) while juvenile fish concentrate riffle areas (Angermeier and Schlosser 1989). Linking various habitat types and establishing connectivity along the length of streams will assist in providing for the needs of fish over their entire lifespan. Anglin and Grossman (2013) concluded that seasonal habitat variation preference can be explained by density and young of the year 
recruitment, where adult brook trout select lower velocity habitats with large substrata and greater amounts of cover throughout the year, forcing sub-adults to utilize sub-optimal habitat when preferred habitat becomes constrained due to changing physical conditions during summer. Larger brook trout display non-random microhabitat selection, selecting habitat based on maximization of net energy gain. Thus, smaller brook trout may experience greater mortality when forced out of limited optimal habitat by adult trout (Anglin and Grossman 2013). Ultimately, this bottleneck will constrain population growth over time. Restoration projects must aim to remove these bottlenecks by alleviating the most limiting habitat resource.

Bond and Lake (2003) note that the removal of dispersal barriers is a critical component of effective restoration projects. Culverts and dams are major barriers to longitudinal fish movement and restrict access to potential spawning grounds, thermal refugia, and food sources, limit genetic diversity, and restrict re-colonization rates (Poplar-Jeffers et al. 2009). Barriers can also limit the flow of sediment, woody debris and organic material from moving downstream, reducing the overall productivity of the system. As a result, the loss of stream connectivity significantly contributes to fish population declines (Roni et al. 2002).

The dispersal abilities and spatial proximity of priority species must be considered when designing restoration projects. Colonization by new species is entirely reliant on the dispersal of organisms from existing populations (MacDougall and Turkington 2005). Rates of colonization will generally depend on the distance between the restored areas and potential source populations. Restoring habitats close to source populations diminishes colonization time for the target species and can accelerate the return of the system to its original community composition. Scale is also an important consideration during restoration projects (Bond and Lake 2003). Many small-scale restoration projects are overshadowed by pre-existing disturbances in 
the watershed. Even if appropriate habitat is restored, doing so at the wrong scale can result in a failed project. For example, projects attempting to decrease water temperature and nutrient levels must be hundreds of meters in length to accomplish their goals. Merovich et al. (2013) noted that appropriate scale and spatial context are key elements in prioritizing stream reaches for habitat restoration. Focusing restoration efforts in severely degraded areas that are surrounded by ecologically degraded communities will limit success, because there are few avenues for target species to repopulate the area. A main goal of habitat restoration is improvement of fish habitat and the growth of the fish communities (Larson et al. 2001). Because structural habitat is only one key aspect of the improvement of fish communities and biological recovery, biological conditions must be monitored post restoration and compared to pre-restoration data to determine if structural improvement is the only measure needed to improve a specific fish community (Larson et al. 2001; Lepori et al. 2005; McClurg et al. 2007). Larson et al. (2001) found that watershed disturbance was considered to overwhelm any improvement that could potentially be made from physical restoration. It is unrealistic to expect increased biodiversity or increased biomass when a restored stream has poor water quality or barriers to colonization. However, in undisturbed streams or streams where ecosystem processes have been restored, physical restoration can have a significant impact on biological diversity (McClurg et al. 2007).

Successful restoration projects must address ecological degradation resulting from landuse practices, remove barriers to dispersal, and incorporate designs meant to maximize benefit to target species, while minimizing benefits to non-native species. Currently, there is a lack of research addressing the impact of restoration on habitat use by native and non-native salmonds. Specifically, there is no research defining microhabitat use by brook trout, brown trout and 
rainbow trout in the context of restoration. Further research is needed to improve the design and implementation of future restoration practices.

\section{Habitat restoration and the expansion of exotic species}

While habitat restoration is often designed to increase biomass of target species, restoration can facilitate the expansion of exotic species (Grarock et al. 2014). The spread of exotic species has been listed among the top causes of biodiversity loss, is one of the largest drivers of changing ecosystems worldwide, and results in substantial economic costs (Sakai et al. 2001; Gurevitch and Padilla 2004; Light and Marchetti 2007; Crowl et al. 2008). Both natural and anthropogenic disturbance can advance the spread of exotic species. Exotic species are often the first species to recolonize new areas after habitat alterations, even if they were not present prior to alteration. D'Antonio and Meyerson (2002) note that some exotic species are short-lived and are quickly outcompeted by native species; however, in many instances the introduction of exotic species can represent a long-term shift of an area's species composition

Habitat modification can benefit invasive species and hurt biodiversity in aquatic environments, limiting benefit to target species. For example, Neumann and Wildman (2002) found that installation of LWD into stream systems has increased exotic brown trout populations, limiting the benefit to native brook trout due to density dependence (Dunham and Vinyard 1997). Anthropogenic disturbance is closely linked to increased rates of exotic species introduction within waterways. Both channel alteration, species translocation, and landscape modification all can impact the quality of aquatic environments and can alter these environments to make them favorable to exotic species (Mills et al. 1994). In general, human disturbance in an environment is highly correlated to the number of invasive species present (Light and Marchetti 
2007). The introduction of exotic species can cause a reduction in the populations of native species, even if they do not establish long-term residency in an aquatic ecosystem (Parker et al. 1999).

Vitousek et al. (1996) concluded that once exotic species become established in a new environment, the process can be difficult to reverse. MacDougall and Turkington (2005) argue that there are two main pathways to species dominance. First, successful exotic species possess better access to limited resources. New species must exploit resources better than native species to become established in an area. This increased demand on resources results in decreased availability, eventually suppressing or excluding species and ultimately resulting in decreased biodiversity. Second, they argue that exotic species may not be impacted by limited resources as much as established native species. Invasive species can become dominant when they are resistant to resource shortages. This allows for greater physical growth, eventually allowing them to displace native species. This type of dominance arises not from competition, but rather from some other environmental factor that suppresses population of native species. Any deviation from the original habitat condition can foster the introduction of new invasive species and negatively influence the diversity of native species.

Connectivity is a goal in many restoration projects; however, this may provide an avenue for invasive aquatic organisms to occupy new areas (Jansson et al. 2007). Angermeier and Schlosser (1989) found that proximity of suitable habitat patches to one another greatly influenced species' ability to expand and contract their range. Exotic and invasive species dispersal into new territories can ensue much more rapidly once initial colonization and establishment has occurred by spreading laterally to suitable habitat areas. Long-distance dispersal typically continues in the presence of lateral migration, compounding the rate of inflow 
of invasive and exotic species (Sakai et al. 2001). Restoration efforts must be focused at an appropriate scale as to maximize restoration goals, while minimizing the potential for aiding in exotic species dispersal. While Merovich et al. (2013) focused on the concept of prioritizing restoration sites based on proximity to good habitat, the same principle can be applied to selecting restoration sites less likely to be colonized by exotic species. Habitat sites in close proximity to potentially invasive exotic species must be carefully monitored to ensure expansion in minimized. Evidence from terrestrial habitats suggests that invasive species can benefit from aquatic restoration and must be taken into consideration when planning out restoration programs.

Climate change is expected to exacerbate the spread of invasive species, especially in coldwater systems (Crowl et al. 2008; Rahel and Olden 2008). Warming waterways, changing stream flow patterns, and increased weather variability are expected to have large impacts on the distribution on numerous aquatic species. Many species that were limited by cold water temperatures will expand their distributions northward as global temperatures continue to rise. In addition, high elevation streams that were traditionally too cold for many species could become suitable habitat for warmwater species. Some models predict that warmwater fish habitat could increase by as much as $31 \%$ (Rahel and Olden 2008). For example, exotic brown trout display a competitive advantage over brook trout in warmer stream reaches (Taniguichi et al. 1998), leading to lower expected brook trout occurrence and abundance in the presence of brown trout under current climate models (McKenna et al. 2013). This will result in increased competition for existing cold water inhabitants, and will result in severe thermal stress for stenothermic organisms. This could shift the distribution of brook trout further north or result in greater fragmentation as populations become relegated to higher elevations (Keleher and Rahel 1996). 
Monitoring the spread and distribution of invasive species and their impacts on native assemblages is essential to understand long-term ecological responses (Crowl et al. 2008).

\section{Assemblage organization and habitat selection in freshwater ecosystems}

Habitat availability and habitat diversity have been found to be reliable predictors of the number of species present, species diversity, and assemblage composition (Grossman et al. 2008). Assemblage organization of freshwater fishes relies on resource limitation, environmental variability, and predation (Grossman et al. 1998). In habitats where assemblage organization is dominated by resource limitations, assemblage structure is driven by resource availability and competitive abilities of assemblage members. This typically creates a fairly stable system because species minimize interspecific competition by occupying unique niches. Partitioning of limited spatial resources is an important mechanism for coexistence of stream fishes. However, in areas where assemblages are controlled by environmental fluctuation, assemblage structure varies significantly and competition for resources becomes more pronounced. Environmental variation reduces species abundance and shifts competitive advantages from one species to another (Grossman et al. 1998). Floods and droughts play a large role in stream assemblages, especially in headwater systems, where flows can vary greatly within short period of time. Consequently, brook trout commonly reside in systems that exhibit high levels of environmental variability. In downstream habitats, the assemblages may be controlled by competition and predation. In predator dominated systems, assemblage structures can vary considerably with predator populations (Grossman et al. 1998).

Stream connectivity has a significant influence on fish assemblages. For example, fish assemblages among connected streams tend to be similar due to ease of dispersal (Hitt and 
Angermeier 2008, Martin and Petty 2009, Hitt and Roberts 2012). Hitt and Roberts (2012) found that local fish communities are regulated by habitat, colonist availability, and interplay of regional factors. Fish in headwater streams are often adapted to environmental variability, allowing species within these streams to recolonize areas quickly after a major environmental disturbance. In larger stream reaches, fish species are not accustomed to significant environmental variation, and therefore take longer to re-colonize an area. Changes in fish species communities will occur over time due to temporal variation of stream structure.

Micro-habitat selection of individual fish is a result of food availability, dominance hierarchies, and temperature and velocity regimes that maximize growth (Bratten and Berry 1997, Thompson et al. 2001, Petty and Grossman 2010). For example, salmonids select positions within a stream in deeper pools, close to cover, and at velocities that strike an optimal balance for minimum energy expenditure and maximum foraging opportunities from invertebrate drift (Fauch and White 1981; Cunjak and Power 1986; Facey and Grossman 1990; Flebbe 1999). Interspecific competition and dominance hierarchies in fish communities can have a significant influence on foraging behavior, location within streams, and activity levels of many fish species (Nakano 1995; Petty and Grossman 2004, Petty and Grossman 2010). Dominant fish typically occupy optimal foraging locations, forcing subdominant fish into peripheral sub-par habitats, leading to significant fitness benefits for larger fish (Nakano 1995). Factors influencing the location of dominant fish within streams may change seasonally with changing thermal regimes, food availability, and fish density (Thompson et al. 2001). Larger size and better adaptation to warmer stream temperatures (Tanuguichi et al 1998) likely result in imbalanced interactions between brook trout and exotic brown and rainbow trout, especially at the margins of their range where sympatry between species is most likely to occur. This imbalance in competition could 
force brook trout into sub-optimal stream positions and diminish populations over time. Further study is needed to determine the potential habitat overlap and competition for space between brook trout and exotic trout species.

\section{Underwater observation}

Underwater observation is an effective method for estimating fish abundance, understanding species distributions, and observing species interactions (Mullner et al. 1998; Thurow et al. 2006; Petty and Grossman 2004). Underwater observation is one of the most economical and versatile techniques for studying organisms in their natural habitat. Snorkeling requires little equipment and is one of the simplest ways to observe species underwater, making this technique ideal for remote locations. Snorkeling is ideal for observing feeding behavior, competitive interactions, favored spawning and resting positions, and the size and structure of populations across a wide variety of environments, including rivers, streams, ponds, and lakes (Dolloff et al. 1996).

Snorkeling effectiveness can vary with environmental conditions. Rubble, cobble, and wood debris all conceal fish and therefore lowered accuracy of snorkeling abundance. The most difficult areas to accurately sample are shallow areas with abundant concealment cover (Zubik and Fraley 1988). Visibility and in-stream cover has a large influence on the ability to predict abundance; estimates are most accurate when the stream bank is visible from the main channel midpoint (Mullner et al. 1998). Temperature also can influence abundance and size structure estimates. Mullner et al. (1998) found that juvenile trout move into interstitial spaces when temperatures drop below 10 . At water temperatures less than $9-10{ }^{\circ} \mathrm{C}$, some salmonids also become photonegative and conceal themselves during the day (Zubik and Fraley 1988). 
Light and time of day also can influence data consistency; however, this can be offset by establishing a protocol that calls for sampling to occur during optimum light conditions (Dolloff et al. 1996). Nighttime sampling via snorkeling can be effective, but in long pools, salmonids can detect the dive lights and flee before being counted (Zubik and Fraley 1988). Estimating size can be difficult in underwater observation studies. Mullner et al. (1998) found that dividing snorkeling length estimated by 1.25 negated underwater magnification bias. Zubik and Fraley (1988) found a strong correlation between snorkeling efficiency and fish body size. Larger individuals are more visible and are easier to detect, leading to a positively skewed size structure estimate.

Wildman and Newmann (2001) concluded that pool volume and rootwad area likely decreased the performance of both electrofishing and snorkeling estimates. However, Zubik and Fraley (1988) note that water clarity is one of the greatest factors influencing abundance estimation accuracy. High flow conditions can also negatively impact snorkeling survey results due to increased turbidity and high water velocity. Snorkeling techniques must vary depending on environmental conditions, study site, and study objectives. In general, snorkelers must slowly enter the pools downstream of the study site to minimize disturbance. In deeper pools, the observer can enter the water upstream of the study site and use natural currents to float along the surface of the pool. Divers should allow a short waiting period between entering the pool and making observation to allow fish to return to their normal routine. They should avoid any rapid movement to prevent disturbance to the fish community. In larger stream sections, multiple divers may be needed to effectively survey a pool (Dolloff et al. 1996). 


\section{Goals and objectives}

The information provided in this review highlights the necessity to understand the interactions between brook trout and non-native salmonids in the context of habitat restoration. There is a paucity of research aimed at determining specific habitat use by brook trout, brown trout, and rainbow trout in restored streams, thus we attempt to provide insight into habitat preferences at both the channel unit and reach scale. The long-term goal of this research is to improve restoration practices for native species. The over-riding objective of this project is to assess the response of brook trout to habitat restoration in the Shavers Fork of the Cheat River, West Virginia at both the hydraulic channel unit scale and the micro-habitat scale within individual pools.

Specific Objective 1: Determine the response of brook trout habitat selection to restoration in the presence of non-native salmonids at the hydraulic channel unit scale.

- Quantify changes in densities of brook trout, brown trout, and rainbow trout at the channel unit scale one year before and one and three years post restoration

- Measure changes in habitat variables at the channel unit scale across years to help explains shifts in habitat use

- Relate both trout occurrence and abundance to habitat parameters at the habitat channel unit scale

Specific Objective 2: Quantify and compare habitat use in restored and natural reaches between native brook trout and exotic trout species at the microhabitat scale.

- Map microhabitat availability within both structure and natural pools

- Use direct observation through snorkeling to determine microhabitat use of brook and brown trout within both structure and natural pools 


\section{Literature Cited}

Ahn, S. J.E. Steiguer, R.B. Palmquist, and T.P. Holmes. 2000. Economic analysis of the potential impact of climate change on recreational trout fishing in the southern Appalachian Mountains: An application of a nested multinomial model. Climate Change 45:493-509.

Allen M.R., D.J. Frame, C. Huntingford, C.D. Jones, J.A. Lowe, M. Meinshausen, et al. 2009. Warming caused by cumulative carbon emissions towards the trillionth tonne. Nature 458:1163-1166.

Allan, J.D. Landscapes and rivescapes: the influence of land use on stream ecosystems. Annual review of ecology, evolution, and systematics 257-284.

Anderson, C. S. 1985. The structure of sculpin populations along a stream size gradient. Environmental Biology of Fishes 13:93-102.

Anderson, C.D., B.K. Epperson, M. Fortin, R. Holderegger, P.M.A. James, M.S. Rosenburg, K.T. Schribner, and S. Spear. 2010. Considering spatial and temporal scale in landscape genetic studies of gene flow. Molecular Ecology 19:3565-3575.

Anderson, G.B., M.C. Freeman, B.J. Freeman, C.A. Straight, M.M. Hagler, and J.T. Peterson. 2012. Dealing with uncertainty when assessing fish passage through culvert road crossings. Environmental Management 50:462-477.

Angermeier, P.L. and I.J. Schlosser. 1989. Species-area relationships for stream fishes. Ecology 70:1450-1462.

Anglin, Z.W. and GD Grossman. 2013. Microhabitat use by southern brook trout (Salvelinis fontinalis) in a headwater North Carolina stream. Ecology of Freshwater Fish 22:567577. 
Aunins, A.W., J.T. Petty, T.L. King, M. Schilz, and P.M. Mazik. 20151 River main stem thermal regimes influence population structuring within an Appalachian brook trout population. Conservation Genetics 16:15-29.

Beechie, T., H. Imaki, J. Green, A. Wade, H. Wu, G. Pess, P. Roni, J. Kimball, J. Stanford, P. Kiffney, and N. Mantua. 2012. Restoring salmon habitat for a changing climate. River Research and Applications 28:939-960.

Bernhardt, E.S., M.A. Palmer. J.D. Allan, G. Alexander, K. Barnas, S. Brooks, J. Carr, S. Clayton, C. Dahm, J. Follstad-Shah, D. Galat, S. Gloss, P. Goodwin, D. Hart, B. Hassett, R. Jenkinson, S. Katz, G.M. Kondolf, P.S. Lake, R. Lave, J.L. Meyer, T.K. O’Donnell, L. Pagano, B. Powell, and E. Sudduth. 2005. Ecology. Synthesizing U.S. river restoration efforts. Science 308:66-637.

Beschta, R.L. and W.S. Platts. 1986. Morphological Features of small streams: significance and function. Water Resources Bulletin 22:369-380.

Bjornn, T.C. and D.W. Reiser. 1991. Habitat Requirements of Salmonids in Streams. American Fisheries Society Special Publication 19:83-138.

Blanchfield, P.J., M.S. Ridgeway, and C.C Wilson. 2003. Breeding success of male brook trout (Salvelunus fontinalis) in the wild. Molecular Ecology 12:2417-2428.

Bond, N.R. and P.S. Lake. 2003. Local habitat restoration in streams: the constraints on the effectiveness of restoration for stream biota. Ecological Management and Restoration 4:193-198.

Braaten, P.J., and C.R. Berry. 1997. Fish associations with four habitat types in a South Dakota prairie stream. Journal of Freshwater Ecology 12:477-489. 
Butryn, R.S. D.L Parrish, and D.M. Rizzo. 2013. Summer stream temperatures metrics for predicting brook trout (Salvelinus fontinalis) distribution in streams. Hydrobiologia 703:47-57.

Chapman, D.W. 1966. Food and space as regulators of salmonid populations in streams. The American Naturalist 100:345-357.

Chapman, D. W. and T.C. Bjornn. 1969. Distribution of salmonids in streams, with special reference to food and feeding. In: H. R. MacMillan Lectures in Fisheries. Symp. Salm. Trout in Streams 1968. Univ. Br. Columbia Inst. Fish., pp. 153-76.

Cienciala P. and M.A. Hassan. 2013. Linking spatial patterns of bed surface, texture, bed mobility and channel hydraulics in a mountains stream to potential spawning substrate for small resident trout. Geomorphology 197:96-107.

Clark, J. S., M.S. Carpenter, M. Barber, et al. 2001. Ecological forecasts: an emerging imperative. Science 293:657-660.

Crowl, T.A., T.O. Crist, R.R. Parmenter, G. Belovsky, and A.E. Lugo. 2008. The spread of invasive species and infectious disease as drivers of ecosystem change. Frontiers in Ecology and the Environment 6:238-246.

Cunjak, R.A. and G. Power. 1986. Winter habitat utilization by stream resident brook trout (Salvelinus fontinalis) and brown trout (Salmo trutta). Canadian Journal of Aquatic Sciences 43:1970-1981.

Cyterski M.C. and Barber, C. 2006. Identification and prediction of fish assemblages in streams of the Mid-Atlantic highlands, USA. Transactions of the American Fisheries Society $135: 40-48$ 
D'Antonio, C. and L.A. Meyerson. 2002. Exotic plant species as problems and solutions in ecological restoration: a synthesis. Restoration Ecology 10:703-713.

Diamond, J.M., and M.E. Gilpin. 1980. Turnover noise: contribution to variance in species number and prediction from immigration and extinction curves. The American Naturalist $115: 884-889$.

Dolloff, A., J. Kershner, and R. Thurow. 1996. Underwater Observation. in B.R. Murphy and D.W. Willis, editors. Fisheries Techniques, second edition. American Fisheries Society, Bethesda, Maryland.

Dunham, J.B. and G.L Vinyard. 1997. Relationships between body mass, population density, and the self-thinning rule in stream-living salmonids. Canadian Journal of Aquatic Sciences 54:1025-1030.

Dunham, J. B., B.E. Rieman. 1999. Metapopulation structure of bull trout: influences of physical, biotic, and geometrical landscape characteristics. Ecological Applications, 9: 642-655.

Dunham, J.B., D. S. Pilliod and M.K. Young. 2004. Assessing the Consequences of Nonnative Trout in Headwater Ecosystems in Western North America. Fisheries 29:18-26.

EBTJV 2008. Conserving the Eastern brook trout: Action strategies. Prepared by Conservation Strategy/Habitat Work Group, Eastern Brook Trout Joint Venture.

Facey, D.E. and G.D. Grossman. 1990. The metabolic cost of maintaining position for four North American stream fishes: effects of season and velocity. Physiological Zoology $63: 757-776$.

Fagan, W.F. Connectivity, fragmentation, and extinction risk in dendritic metapopulations. Ecology 12:3243-3249. 
Fausch, K.D. an R.J. White. 1981. Competition between brook trout Salvelinus fontinalis) and Brown Trout (Salmo trutta) for Positions in a Michigan Stream. Canadian Journal of Fisheries and Aquatic Sciences. 38:1220-1227.

Fausch, K.D. C.E. Torgersen. C.V. Baxter, and H.W. Li. 2002. Landscape to riverscape: bridging the gap between research and conservation of stream fishes. Bioscience 52:483-498.

Flebbe, P.A., and C.A. Dolloff. 1995. Trout use of woody debris and habitat in Appalachian Wilderness streams of North Carolina. North American Journal of Fisheries Management 15:579-590.

Flebbe, P.A. 1999 Trout use of woody debris and habitat in Wine Spring, North Carolina. Forest Ecology and Management 114:367-376.

Flebbe, P.A., L.D. Roghair, and J.L. Bruggink. 2006. Spatial modeling to project southern Appalachian trout distribution in a warmer climate. Transactions of the American Fisheries Society 135:1371-1382.

Freeman, M.C. and G.D. Grossman. 1992. Group foraging by a stream minnow: shoals or aggregations? Animal Behavior 44:393-403.

Freeman, M.C. and G.D. Grosssman. 1993. Effects of habitat availability on dispersion of a stream cyprinid. Environmental Biology of Fishes 37:121-130.

Gibson, R. J., R. L. Haedrich, and C. M. Wernerheim. 2005. Loss of fish habitat as a consequence of inappropriately constructed stream crossings. Fisheries 30:10-17.

Godfrey, T. 2006. Shavers Fork. The West Virginia Encyclopedia, Ken Sullivan, editor. Charleston, WV: West Virginia Humanities Council.

Golladay, S.W. and J.R. Webster. 1988. Effects of clear-cut logging on wood breakdown in Appalachian Mountain streams. The American Midland Naturalist 199:143-155. 
Gorman, O.T. and J.R. Karr. 1978. Habitat structure and stream fish communities. Ecology 59:507-515.

Grarock, K. C.B. Tideman, J.T. Wood, and D.B. Lindenmayer. 2014. Are invasive species drivers of native species decline or passengers of habitat modification? A case study of the impact of the common myna (Acridothere tristis) on Australian bird species. Animal Ecology 39:106-114.

Grossman, G.D., R.E. Ratajczak, M. Crawford, and M.C. Freeman. 1998. Assemblage organization in stream fishes: effects of environmental variation and interspecific interactions. Ecological monographs 68:395-420.

Grossman, G.D., P.A. Rincon, M.D. Farr, R.E. Ratakczak. 2002. A new optimal foraging model predicts habitat use by drift-feeding stream minnows. Ecology of Freshwater Fish 11:210.

Grossman, G.D., R.E. Rarajczak, C.M. Wagner, and J.T. Petty. 2010. Dynamics and Regulation of the southern brook trout (Salvelins fontinalus) population in an Appalachian Stream. Freshwater Biology 55:1494-1508.

Grossman G.D., A. Nuhfer. T. Zorn, G. Sutton, and G. Alexander. 2012. Population regulation of brook trout in Hunt Creek, Michigan: A 50 year study. Freshwater Biology 57:14341448.

Gurevitch, J.G. and D.K. Padilla. 2004. Are invasive species a major cause of extinctions? Trends in ecology and evolution 19:470-474.

Gustafsson, S., M. Österling, J. Skurdal, L.D. Schneider, and O. Calles. 2013. Macroinvertebrate colonization of a nature-like fishway: the effects of adding habitat heterogeneity. Ecological Engineering 61:345-353. 
Hartman, K.J. and J.A. Sweka. 2001. Development of a bioenergetics model for Appalachian brook trout. Proceedings of the Annual conference of Southeast Association of Fish and Wildlife Agencies 55:38-51.

Hartman, K.J. and M.N. Logan. 2010. Movement and habitat use by transplanted adult brook trout in an Appalachian headwater stream. Northeastern Naturalist 17:357-372.

Hitt, N.P. and P.L. Angermeier. 2008. River-stream connectivity affects fish bioassessment performance. Environmental Management 42:132-150.

Hitt, N.P. and J.H. Roberts. 2012. Hierarchical spatial structure of stream fish colonization and extinction. Oikos 121:127-137.

Hudy, M., T.M. Thieling, N. Gillespie, and E.P. Smith. 2005. Distribution, status and perturbations to brook trout within the eastern United States. Final Report: Eastern Brook Trout Joint Venture, USFWS, Washington, DC. 76 Pages.

Hudy, M., T.M. Thieling, N. Gillespie, and E.P. Smith. 2008. Distribution, status and land use characteristics of subwatersheds within the native range of brook trout in the eastern native range of brook trout in the Eastern United States. North American Journal of Fisheries Management 28:1069-1085.

Hudy M, J.A. Coombs, K.H. Nislow, B.H. Letcher, 2010. Dispersal and within-stream spatial population structure of brook trout revealed by pedigree reconstruction. Transactions of the American Fisheries Society139:1276-1287.

Hughes, N.F. 1998. A model of habitat selection by drift-feeding stream salmonids at different scales. Ecology 79: 281-294. 
Hughes, N. F. and L. M. Dill. 1990. Position choice by drift-feeding salmonids: model and test for Arctic grayling (Thymallus arcticus) in subarctic mountain streams, interior Alaska. Canadian Journal of Fisheries and Aquatic Sciences47:2039-2048.

Hughes, N. F. 1992. Ranking of feeding positions by driftfeeding Arctic grayling (Thymallus arcticus) in dominance hierarchies. Canadian Journal of Fisheries and Aquatic Sciences 49:1994-1998.

Huntsman, B.R. and J.T. Petty. 2014. Density-dependent regulation of brook trout population dynamics along a core-periphery distribution gradient in a central Appalachian watershed. PLOS One 9:1-14.

Jansson, R. C. Nilsson, and B. Malmqvist. 2007. Restoring freshwater ecosystems in riverine landscapes: the roles of connectivity and recovery processes. Freshwater Biology 52:589596.

Jelks H.L., Walsh S.J., Burkhead N.M. et al. (2008) Conservation status of imperiled North American freshwater and diadromous fishes. Fisheries, 33, 372-407.

Keleher, C.J. and F.J. Rahel. 1996. Thermal limits to salmonid distribution in the Rocky Mountain Region and potential habitat loss due to global warming: and geographic information system approach. Transactions of the American Fisheries Society 125:1-13.

Klotzli, F. and A.P. Grootsjans. 2001. Restoring natural and semi-natural wetland systems in central Europe: progress and predictability of developments. Restoration Ecology 9:209219.

Larson M.G., D.B. Booth and S.A. Morley. 2001. Effectiveness of large woody debris in stream rehabilitation projects in urban basin. Ecological Engineering 18:211-226. 
Lepori Fl., D. Palm, E. Brannas, and B. Malmqvist. 2005. Does restoration of structural heterogeneity in stream enhance fish and macroinvertebrate diversity? Ecological Applications 15:2060-2071.

Letcher, B.H., K.H. Nislow, J.A. Coombs, M.J. O’Donnel, and T. L. Dubreuil. 2007. Population response to habitat fragmentation in a stream-dwelling brook trout population. PloS One 11: e1139

Light, T. and M.P. Marchetti. 2007. Distinguishing between invasions and habitat changes as drivers of diversity loss among California's freshwater fishes. Conservation Biology 21:434-446.

MacCrimmon, H. R., and J. C. Campbell. 1969. World distribution of brook trout, Salvelinus fontinalis. Journal of the Fisheries Research Board of Canada 26:1699-1725.

MacDougall, A.S. and R. Turkington. 2005. Are invasive species the drivers or passengers of change in degraded ecosystems? Ecology 86:42-55.

Magoulick, D.D., M.A. Wilzbach. 1998. Effect of temperature and macrohabitat on interspecific aggression, foraging success, and growth of brook trout and rainbow trout pairs in laboratory systems. Transactions of the American Fisheries Society 127:708-717.

Manel, S., and Holderegger, R. 2013. Ten years of landscape genetics. Trends in Ecology and Evolution 28: 614-621

Marschall, E.A. and L.B. Crowder. 1996. Assessing population responses to multiple anthropogenic effects: a case study with brook trout. Ecological Applications 6:152:167.

Martin, R.W. and J.T. Petty. 2009. Local stream temperature and drainage network topology interact to influence the distribution of smallmouth bass and brook trout in a central Appalachian watershed. Journal of Freshwater Ecology 24:497-508. 
McClurg, S.E., J.T. Petty, P.M. Mazik, and J.L. Clayton. 2007. Stream ecosystem response to limestone treatment in acid impacted watersheds of the Allegheny Plateau. Ecological Applications 17:1087-1104.

McKenna, J.E., M.T. Slattery, K.M. Clifford. 2013. Broad-scale patterns of brook trout responses to introduced brown trout in New York. North American Journal of Fisheries Management 33:1221-1235.

Merovich, G.T., J.T. Petty, M.P. Strager and J.B. Fulton. 2013. Hierarchical classification of stream condition: a house-neighborhood framework for establishing priorities in complex riverscapes. Freshwater Science 32:874-891.

Mills, E.L. J.H. Leach, J.T. Carlton, C.L. Secor. 1994. Exotic Species and the integrity of the Great Lakes. BioScience 44:666-676.

Mullner, S.A., T.A. Wesche and W.A. Hubert. 1998. Snorkeling as an alternative to depletion electrofishing for estimating abundance and length-class frequencies of trout in small streams. North American Journal of Fisheries Management 18:947-953.

Nakamura, T. and F.J. Swanson. 1993. Effects of coarse woody debris on morphology and sediment storage of a mountain stream system in western Oregon. Earth Surface Processes and Landforms 18: 43-61.

National Research Council (NRC). 1992. Restoration of aquatic ecosystems: science, technology, and the public. National Academy Press, Washington, D.C.

Nakano, S. 1995. Differences in resource use, growth, and emigration under the influences of a dominance hierarchy in fluvial red-spotted masu samon in a natural habitat. Journal of America Ecology 64:75-84. 
Neville, H. M., J.B. Dunham, and M.M. Peacock. 2006. Landscape attributes and life history variability shape genetic structure of trout populations in a stream network. Landscape Ecology, 21: 901-916.

Nilsson, C., F. Leporti, Bjorn Malmqvist, E. Tornlund, N. Hjerdt, J.M. Helfield, D. Palm, J. Ostergren, R. Jansson, E. Brannas, and H. Lundqvist. 2005. Forecasting environmental response to reforestation of rivers used as log floatways: an interdisciplinary approach. Ecosystems 8:779-800.

Nielsen, J.L., T.E. Lisle, V. Ozaki. 1994. Thermally stratified pools and their use by steelhead in a Northern California Stream. Transactions of the American Fisheries Society 123:613626.

Ohlund, G., F Nordwall, E. Degerman, T. Eriksson. 2008. Life history and large-scale habitat use of brown trout (Salmo trutta) and brook trout (Salvelinus fontanalis)- implications for species replacement patterns. Canadian Journal of Aquatic Science 65:633-644.

Palmer, M.A., R.F. Ambrose, N.L. Poff. 1997. Ecological theory and community restoration ecology. Restoration Ecology 5:291-300.

Parker, I.M., D. Simberloff, W.M. Lonsdale, K. Goodell, M. Wonham, P.M. Kareiva, M.H. Williamson, B. Won Holle, P.B. Moyle, J.E. Byers, and L. Goldwasser. 1999. Impact: toward a framework for understanding the ecological effects of invaders. Biological Invasions 1:3-19.

Petty, J. T., J. Freund, P. Lamothe, and P. Mazik. 2001. Quantifying in stream habitat in the upper Shavers Fork basin at multiple spatial scales. Proceedings of the Annual Conference of the Southeastern Association of Fish and Wildlife Agencies 55:81-94. 
Petty, J.T. and G.D. Grossman. 2004.Restricted movement by mottled sculpin (pisces: cottidae) in a southern Appalachian stream. Freshwater Biology 49:631-645.

Petty, J.T. and G.D. Grossman. 2010. Giving-up densities and pre-emptive patch use in a predatory benthic stream fish. Freshwater Biology 55:780-793.

Petty, J.T., P.J. Lamothe, and P.M. Mazik. 2005. Spatial and seasonal dynamics of brook trout populations inhabiting a central Appalachian watershed. Transactions of the American Fisheries Society 134:572-587.

Petty, J.T., J.B. Fulton, M.P. Strager, G.T. Merovich, J.M. Stiles, and P.F. Ziemkiewics. 2010. Landscape indicators and thresholds of stream ecological impairment in an intensively mined Appalachian watershed. Journal of the North American Benthological Society 29:1292-1309.

Petty, J. T. and E.P. Merriam. 2012. Brook Trout Restoration. Nature Education Knowledge 3:17.

Petty, J.T., J.L. Hansbarger, B.L. Huntsman, and P.M. Mazik. 2012. Brook trout movement in response to temperature, flow, and thermal refugia within a complex Appalachian riverscape. Transactions of the American Fisheries Society 141:1060-1073.

Petty, J.T., D. Thorne, B.L. Huntsman, and P.M. Mazik. 2014. The temperature productivity squeeze: constraints on brook trout growth along an Appalachian River continuum. Hydrobiologia 727:151-166.

Pool, G.C. and C.A. Berman. 2001. An ecological perspective on in-stream temperature: natural heat dynamics and mechanisms of human-caused thermal degradation. Environmental Management 27:787-802. 
Poplar-Jeffers. I.O, J.T. Petty, J.T. Anderson, S.J. Kite, M.P. Strager, and R.H. Fortney. 2009. Culvert replacement and stream habitat restoration: implications from brook trout management in an Appalachian watershed, U.S.A.. Restoration Ecology 17:404-413.

Post, D. M., J.F. Kitchell, and J.R. Hodgson. 1998. Interactions among adult demography, spawning date, growth rate, predation, overwinter mortality, and the recruitment of largemouth bass in a northern lake. Canadian Journal of Fisheries and Aquatic Sciences, $55: 2588-2600$.

Rahel, F.J. and J.D. Olden. 2008. Assessing the effects of climate change on aquatic invasive species. Conservation Biology 22:521-533.

Richards, C. L.B. Johnson, and G.E. Host. Landscape-scale influences on stream habitats and biota. Canadian Journal of Fisheries and aquatic sciences.53:295-311.

Roni, P. and T.P. Quinn. 2001. Density and size of juvenile salmonids in response to placement of large woody debris in western Oregon and Washington streams. Canadian journal of fisheries and aquatic sciences, 58:282-292.

Roni, P., T.J Beechie, R.E. Bilby, F.E. Leonetti, M.M. Pollock, and G.R. Pess. 2002. A review of stream restoration techniques and a hierarchical strategy for prioritizing restoration in Pacific Northwest watersheds. North American Journal of Fisheries Management 22:120.

Sakai, A.K., F.W. Allendorf, S. Holt, D.M. Lodge, J. Molofsky, K.A. With, N.C. Ellstrand, D.E. McCauley, P. O’Neil, I.M. Parker, J.N. Thompson, and S.G. Weller. 2001. The population biology of invasive species. Annual Review of Ecological Systems 32:305332. 
Schlosser, I.J. 1982. Stream fish ecology: a landscape perspective. Ecological Monographs 41:04-712.

Sear, D.A., Frostick, L.B., Rollinson, G., Lisle, T.E., 2008. The significance and mechanics of fine-sediment infiltration and accumulation in gravel spawning beds. In: Sear, D.A., DeVries, P. (Eds.), Salmonid Spawning Habitat in Rivers: Physical Controls, Biological Responses and Approaches to Remediation. American Fisheries Society Symposium, 65. American Fisheries Society, Betsheda, MD, pp. 149-173.

Smith, K. and M.E. Lavis. 1975. Environmental influences on the temperature of a small upland stream. Oikos 26:228-236.

Stranko, S.A., R.H. Hilderbrand, R.P. Morgan, M.W. Staley, A.J. Becker, A. RosenberryLincoln, E.S. Perry, and P.T. Jacobson. 2008. Brook trout temperature declines with land cover and temperature changes in Maryland. North American Journal of Fisheries Management 28:1223-1232.

Sullivan, K., T.E. Lisle, C.A. Dolloff, G.E. Grant, G.E. and L.M. Reid,L.M. 1987. Stream channels: the link between forests and fishes, pp. 39-97 In: Salo, E.O. \& Cundy, T.W., eds.Streamside management: forestry and fishery interactions.University of Washington, Seattle.

Symons, P.E.K. (1971). Adjustment to population density to food available food by juvenile Atlantic Salmon. Journal of Animal Ecology 40:569-587.

Taniguichi, Y., D. C. Novinger, F. J. Rahel, and K. Gerow. 1998. Temperature mediation of competitive interactions among three fish species, brook trout, brown trout, and creek chub, that replace each other along longitudinal stream gradients. Canadian Journal of Fisheries and Aquatic Sciences 55:1894-1901. 
Taniguchi, Y. and S. Nakano. 2000. Condition Specific Competition: Implications for the altitudinal distributions of stream fishes. Ecology 81:2027-2039.

Tatarenkov A., C.I.M. Healey, and J.C. Avise. 2010. Microgeographic population structure of green swordtail fish: genetic differentiation despite abundant migration. Molecular Ecology 19:257-268.

Thurow, R.F. J.T. Peterson, and J.W. Guzevich. 2014. Utility and validation of day and night snorkel counts in first to third order streams. North American Journal of Fish Management. 26:217-232.

Torgersen, C.E., D.M. Price, H.W. Li, and B. A. McIntosh. 1999. Multiscale thermal refugia and stream habitat associations of Chinook salmon in northeastern Oregon. Ecological Applications 9: 301-319.

Trumbo, B., M. Hudy, E.P. Smith., D.Y. Kim, B.A. Wiggins, K.H. Nislow, and C.A. Dolloff, 2010. Sensitivity and vulnerability of brook trout populations to climate change. In Proc 10th Annual Wild Trout Symposium, West Yellowstone, MT.

Vietz, G.J., M.J. Sammonds, C.J. Walsh, T.D. Fletcher, I.D. Rutherfod, M.J. Stewardson. 2014. Ecologically relevant geomorphic attributes of streams are impaired by even low levels of watershed effective imperviousness. Geomorphology 206:67-78.

Vitousek P.M., C.M. D'Antonio, L.L. Loope and R.Westbrooks. 1996. Biological invasions as global environmental change. Am. Sci. 84:218-228.

Wagner, T., J.T. Deweber, J. Detar, and J.A. Sweka. 2013. Landscape-scale evaluation of asymmetric interactions between brown trout and brook trout using two-species occupancy models. Transactions of the American Fisheries Society 142:353-361. 
Waples, R.S., T. Beechie, and G.R. Pess. 2009. Evolutionary history, habitat disturbance regimes, and anthropogenic changes: what do these mean for resilience of Pacific salmon populations? Ecology and Society 14:3.

Warnock, W.G. and J.B. Rasmussen. 2013. Abiotic and biotic factors associated with brook trout invasiveness into bull trout streams of the Canadian Rockies. Canadian Journal of Fisheries and Aquatic Sciences,70:905-914.

Warren, D. R., J. M. Robinson, D. C. Josephson, D. R. Sheldon \& C. E. Kraft, 2012. Elevated summer temperatures delay spawning and reduce redd construction for resident brook trout (Salvelinus fontinalis). Global Change Biology 18:1804-1811.

Wenger, S. J., D. J. Isaak, C. H. Luce, H. M. Neville, K.D. Fausch, J. B. Dunham, D. C. Dauwalter, M. K. Young, M. M. Elsner, B. E. Rieman, A. F. Hamlet and J. E. Williams, 2011. Flow regime, temperature, and biotic interactions drive differential declines of trout species under climate change PNAS 108: 14175-14180.

Wilby, R.L., H. Orr, G. Watts, R.W. Battarbee, P.M. Berry, R. Chadd, S.J. Dugdale, M.J. Dunbar, J.A. Elliott, C. Extence, D.M. Hannah, N. Holmes, A.C. Johnson, B. Knights, N.J. Milner, S.J. Ormerod, D. Solomon, R. Timlett, P.J. Whitehead, P.J. Wood. 2010. Evidence needed to manage freshwater ecosystems in a changing climate: Turning adaptation principles into practice. Science of the Total Environment. 408:4150-4164.

Wildman, T.L. and T.L. Neumann. 2001. Comparison of snorkeling and electrofishing for estimating abundance and size structure of brook trout and brown trout in two southern New England streams. Fisheries Research 60:131-139.

Willis, T.V. and J.M. Magnuson. 2006. Response of fish communities in five north temperate lakes to exotic species and climate. Limnology and Oceanography 51:2808-2820. 
Whitleley, A.R., J.A. Coombs, M. Hudy. Z. Robinson. A.R. Colton, K.H. Nislow, and B.H. Letcher. 2013. Fragmentation and patch size shape genetic structure of brook trout populations. Canadian Journal of Fisheries and Aquatic Sciences 70:678-688.

Xu, C., B. H. Letcher \& K. H. Nislow, 2010. Context-specific influence of water temperature on brook trout growth rates in the field. Freshwater Biology 55: 2253-2264.

Zubik, R.J. and J.J. Fraley. 1988. Comparison of snorkel and mark-recapture estimates for trout populations in large streams. North American Journal of Fisheries Management 8:58-62. 
Figures

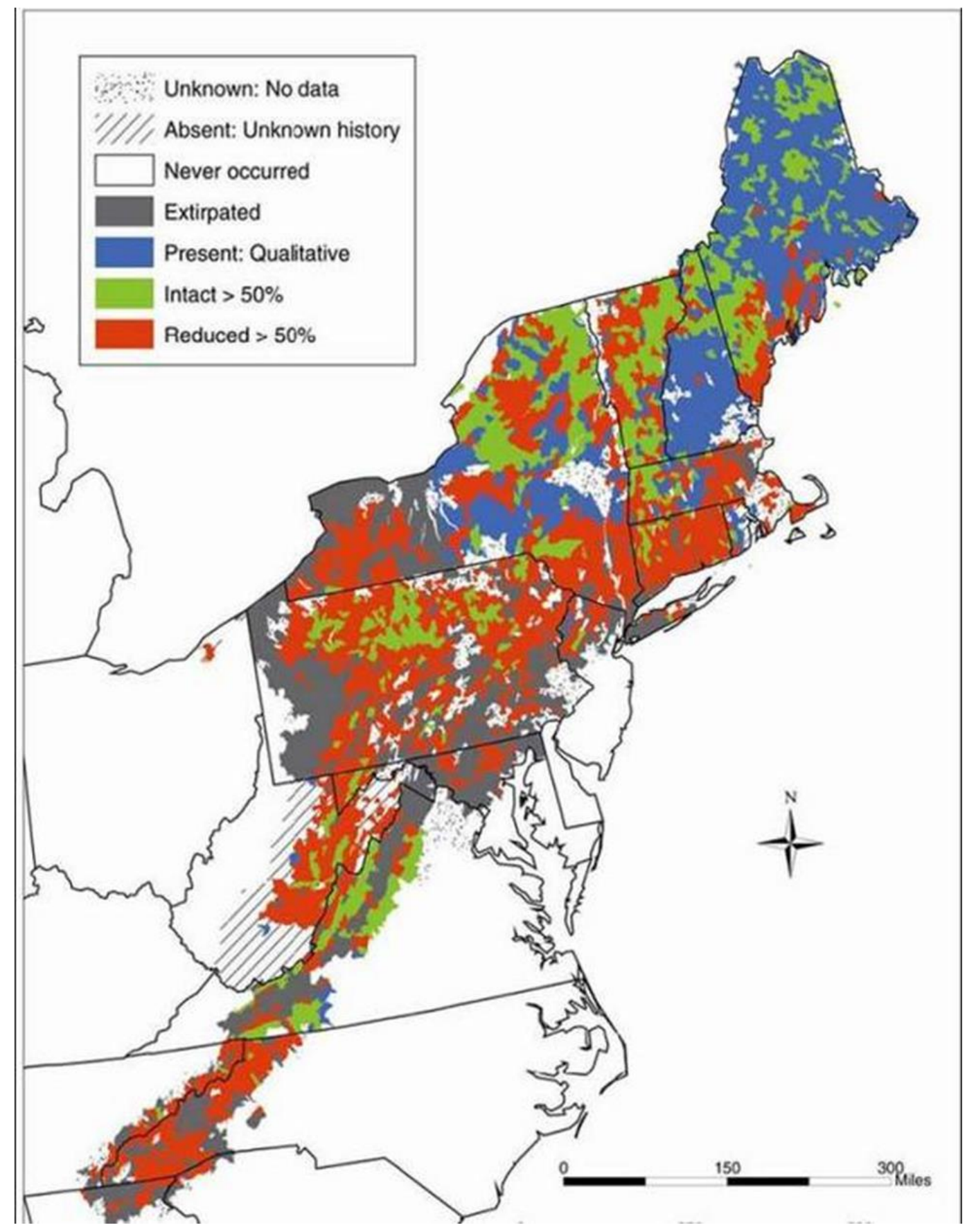

Figure 1: Figure 1: Map showing brook trout population status compared with their historical range (Hudy et al. 2008) 


\title{
Chapter 2: Temporal evaluation of salmonid habitat use before and after a multi-scale habitat enhancement project
}

\begin{abstract}
Brook trout Salvelinus fontinalis have experienced significant population declines throughout much of their native range, largely due to habitat loss. Increasing effort has been put toward restoring and preserving existing brook trout habitat in the face of continued loss under uncertain future conditions (e.g., climate change). We conducted a before-after-control-impact assessment of a multi-scale restoration project designed to improve brook trout habitat on the Shavers Fork, West Virginia. Our specific objectives were to first quantify changes in densities of brook trout and two competing trout species (brown trout Salmo trutta and rainbow trout Oncorhynchus mykiss) at the channel unit scale. We then determine differences in habitat variables within respective hydraulic channel unit classifications across years. Finally, we relate both trout occurrence and abundance to habitat parameters at the habitat channel unit scale to help explain shifts in distribution and habitat use in response to restoration. Prior to restoration, brook trout were most dense in riffle habitats, while brown trout tended to occupy natural pools. Following restoration, all 3 trout species occupied constructed pool habitats; however, brook trout consistently occupied constructed habitats at densities $4.5 \times$ those of brown trout. Total trout densities declined one year after restoration, driven primarily by reductions in rainbow trout numbers. Pools, riffles, intermediate-gradient complexes, and low-gradient complexes all experienced slower velocities after restoration work, but depth did not change across units. General linear mixed models indicate that trout abundance for all species is inversely correlated with average distance to fish cover within a channel unit, while average depth is inversely correlated to brook trout abundance. Overall, shifts in habitat were influenced by restoration
\end{abstract}


activities, and all three species occupied newly created pools within three years of completion. Shifts in brown trout abundances and overall population declines suggests that these newly created habits may be acting as attractive sinks as a result of concentrated angling pressure. Further study is needed to determine habitat preferences at the microscale.

\section{Introduction}

Significant anthropogenic degradation of aquatic habitats including sedimentation, thermal impairment, habitat fragmentation, lowered water quality, and channel homogenization has occurred across the globe over the past century (Hudy et al. 2000; Curry and MacNeill 2004; McClurg et al. 2007; Poplar-Jeffers et al. 2009; Snyder et al. 2015). Anticipated increases in stream temperature (Isaak and Rieman 2013; Snyder et al. 2015) have heightened the need for multi-scale restoration projects, especially for thermally sensitive species (Hudy et al. 2008). Stream channel restoration and structural habitat enhancement are often designed to restore aquatic ecosystems to specifically benefit native species (Bond and Lake 2003; Petty and Merriam 2012). These projects attempt to use physical habitat restoration to create suitable habitat for target species within the stream channel.

Brook trout Salvelinus fontinalis populations have experienced significant habitat loss and subsequent population declines during the past century due to anthropogenic landscape alterations, overharvest, and competition from non-native salmonids (Petty and Merriam 2012). Hudy et al. (2008) found that brook trout are likely reduced or extirpated from $>60 \%$ of their range at the subwatershed scale and currently exist as highly fragmented populations across much of their range. Consequently, brook trout have been the focal species for a wide range of restoration efforts (Hartman and Sweka 2006; McClurg et al. 2007; Poplar-Jeffers et al. 2009; 
Anderson et al. 2012). Past efforts at influencing brook trout populations include stocking and instream habitat modification (Flebbe 1999), but more recent management efforts have focused almost exclusively on restoring favorable brook trout habitat. These projects typically aim to foster population growth, and thus are seen as more long-term, sustainable solutions to stymie brook trout population loss (Larson et al. 2001; Lepori et al. 2005; McClurg et al. 2007).

While there is abundant literature focused on the landscape-level predictors of trout occupancy (Hudy et al. 2008; Wagner et al. 2013; DeWeber and Wagner 2015), there is a paucity of research examining factors influencing brook trout presence and abundance at the reach scale and how changes of in-stream physical habitat characteristics at the channel unit scale influence brook trout occupancy and abundance. Additionally, little is known about the impact of changes in physical habitat parameters to reach-scale habitat selection by non-native salmonids, such as brown trout Salmo trutta, and rainbow trout Oncorhynchus mykiss.

Numerous studies have focused on interactions between brook trout and other salmonid species (Fausch and White 1981; Magoulick and Wilzbach 1998; Ohlund et al. 2008; Butryn et al. 2013; McKenna et al. 2013; Wagner et al. 2013). Growing evidence suggests that non-native trout can significantly alter aquatic ecosystems and can negatively impact native species' abundance due to excessive competition for limited resources (Fausch and White 1981; Fausch and White 1986; DeWald and Wilzbach 1992; Dunham et al. 2004; Wagner et al. 2013). Brook trout exhibit a lower probability of expected occupancy in the presence of brown trout (Faush and White 1981; McKenna et al. 2013; Wagner et al. 2013). Brown trout have a higher thermal tolerance than brook trout and exhibit greater growth rates and maximum size giving them a competitive advantage (Taniguichi et al. 1998). Rainbow trout have also replaced brook trout populations in many stream segments in the southern Appalachians, likely due to higher 
reproductive rates, greater size and competitive abilities, and superior ability to adapt to warming stream conditions (Larson and Moore 1985; Clark and Rose 1997).

While previous studies have examined the influence of restoration on the distribution of native species assemblages in the presence of brown trout (Belk et al. 2016), to our knowledge no study has examined the habitat preferences of brook trout and exotic salmonids within the context of habitat restoration. We provide such an assessment within the upper Shavers Fork of the Cheat River, West Virginia. The overall goal of this study is to characterize brook trout response to a large scale (4.5 stream miles) restoration project designed to improve brook trout habitat availability. To determine the response of brook trout to habitat restoration in the presence of non-native salmonids, we attempted to do the following: : 1) quantify changes in densities of brook trout, brown trout, and rainbow trout at the channel unit scale one year before and one and three years post restoration, 2), measure changes in habitat variables at the channel unit scale across years to help explains shifts in habitat use and 3) relate both trout occurrence and abundance to habitat parameters at the hydraulic channel unit scale. More specifically, to determine the response of brook trout to habitat restoration in the presence of non-native salmonids, we first measured changes in habitat characteristics at the channel-unit scale. We then characterized shifts in distributional patterns at the channel unit scale. Finally, we related observed distribution patterns to habitat characteristics at the channel unit scale.

\section{Methods}

Study Area

The Upper Shavers Fork Watershed (Figure 1) is a high elevation (originates at 1500m) $156 \mathrm{~km}^{2}$ watershed located primarily in the Monongahela National Forest in east-central West 
Virginia (Huntsman and Petty 2014). The Shavers Fork flows north until its confluence with the Black Fork to form the Cheat River near Parsons, WV. Brook trout, brown trout and rainbow trout are all found within the main channel of Shavers Fork, while brook trout dominate the numerous headwater tributaries. Shavers Fork once supported a thriving brook trout fishery, but degradation due to acid precipitation, sediment deposition, and channel and riparian modification from decades of timber harvest activity have hindered populations throughout the latter half of the twentieth century (Petty et al. 2005).

In 2012, habitat structures were installed along a four and a half mile section of the upper Shavers Fork. The project included the construction of single-wing deflectors, rock vanes, and woody habitat structures, such as root wads and bank sills, and was designed to narrow the channel, increase velocity, and create pools and riffle areas. The main goal of the Shavers Fork restoration plan was to restore foraging, reproductive, and refuge habitat for brook trout.

Eight long-term study reaches were sampled during this experiment (Figure 1). Four treatment reaches (Below Second, East to West, Ryan's Bend and Below Rocky Run) are located within the habitat restoration project site, while four control reaches (Beaver Creek, Twin Trestles, Below Lamothe, and Above Lamothe) were located outside of the habitat restoration project. Study reach lengths were approximately forty times the average active channel width.

\section{Data Collection}

A before-after-control-impact design was used to assess changes in trout densities and habitat parameters in both control and treatment sites. Trout populations were sampled in all eight study reaches during the first two weeks of June in 2011, 2013, and 2015 using single-pass backpack electrofishing techniques. All trout were weighed, measured, and released at their 
approximate location of capture. A triple-pass depletion method was used each spring in one main stem site to compare capture rates across years.

During the spring sampling period, hydraulic channel units (HCU's) were classified visually based off of characteristics defined by Petty et al. (2001). HCU's were assigned to one of five categories: low gradient complexes (LOW), intermediate gradient complexes (INT), intermediate gradient riffles (IGR), natural pools (NAT), and structure pools (STR). Structure pools were pools created in 2012 during a restoration of the upper Shavers Fork watershed. Reach length and the total number of trout captured in each HCU were recorded, and trout density (\#/m) in each HCU was calculated for each species.

Habitat data, including depth $(\mathrm{cm})$, average velocity $(\mathrm{m} / \mathrm{s}$, collected at $60 \%$ of stream depth), bottom velocity, fastest velocity within 60 centimeters of the data point, distance to cover (m), and substrate type were collected during low flow conditions $(40+/-10 \mathrm{cfs})$ at both treatment and control sites before (2011) and after (2013 and 2015) restoration. Prior analyses within this system have found that these variables contribute significantly to brook trout habitat suitability (Hansberger et al. 2008). Data were collected in the thalweg at intervals equivalent to one-half of the active channel width through the length of each study reach. Velocity was measured using Flo-mate Model 200 portable flow meters (Marsh-McBriney, Inc.). Flow data were acquired from the United States Geological Service gauging station at Cheat Bridge (\#03065710), located approximately 10 miles downstream from the start of our sampling sites. In 2013 and 2015, habitat data were linked to hydraulic channel units defined during the fish sampling period. A total of $180 \mathrm{HCU}$ 's were sampled between these two years.

\section{Statistical Analyses}




\section{Hydraulic Channel Unit Characteristics}

Mean and standard deviation of each habitat variable were calculated for all HCU's across both treatment and control sites. Temporal differences in habitat parameters were evaluated using linear mixed models using the nlme package in R (Pinheiro et al. 2017). Restricted maximum likelihood linear mixed-model analyses were run to determine differences in depth, average velocity, and distance to fish cover across years and treatment types. Variables were normalized using log transformation. Treatment (i.e. restored and non-restored reaches), year, and a treatment-by-year effect were included as fixed effects for each model and we allowed intercepts to vary among hydraulic channel units by including them in the random effects portion of the model. Residuals for each model were plotted against fitted values for each model to check for any skewness within the models.

\section{Distributional Shifts at the Channel Unit Scale}

We summarized brook trout, brown trout, rainbow trout, and total trout densities for each HCU type across treatment, control, and all sites for each year. Total trout densities were also computed for each species within control and treatment sites across years. We then used regression analysis to determine the effect of year, treatment (i.e., restoration activity), and HCU on brook, brown, rainbow, and total abundances. Due to a large number of HCU's that did not contain any trout, we ran zero-inflation regression models using the zeroinfl package in $\mathrm{R}$ (Zeileis et al. 2008). We offset count data by the log of each HCU length. Structure pools were grouped with natural pools for this analysis because of their absence from the 2011 data. We first created a global model containing individual effects of year, HCU, and treatment, as well as all two- and three-way interactions. Subsequent models were created by step-wise deletion of 
variables. Model selection using second-order Akaike's information criterion (AICc) was accomplished using the package MuMIn (Barton 2015). Models with the lowest AICc value were interpreted, but all models with a $\triangle \mathrm{AICc}$ of $<2$ were reported. Because slope coefficients were similar across models and were close to zero, model averaging was avoided (Cade 2015).

\section{$\underline{\text { Characteristics Influencing Trout Distribution }}$}

To determine the influence of depth, velocity, and distance to fish cover on trout occupancy, habitat variables between occupied and unoccupied reaches were compared within hydraulic channel unit type across years using ANOVA. The number of channel units containing brook trout, brown trout, sympatric populations, and no trout were then calculated for 2013 and 2015 to determine if HCU impacts the likelihood of sympatry between brook and brown trout.

General linear mixed models were then used to describe the relationship between habitat variables and trout abundance. Habitat parameters, including depth, average velocity, and distance to fish cover, were included as fixed effects. We allowed intercepts to vary among years within treatment type (i.e., treatment:year random effect) to account for spatial and temporal variation in fish densities. Models were run using the glmmADMB package in R (Skaug 2006). Depth, average velocity, distance to fish cover, and an interaction between depth and distance to fish cover were included in the global model. Subsequent models were created by removing the least significant term from each prior model. A log likelihood test determined a negative binomial distribution best fit the total trout count data because of excessive dispersion in the data. A poisson distribution was used for both brook trout, brown, and rainbow trout models. All models, except for brown trout, were run to control for zero inflation within the data. Model 
selection was conducted using AICc using the package MuMIn (Barton 2015). All statistical analyses were completed in R 3.0.2 (R Core Team 2013).

\section{Results}

Habitat Parameter changes at the Habitat Channel Unit scale

Means and standard deviations of habitat parameters for all HCU's across years and within control and treatment sites are summarized in Table 1. Linear mixed models (Table 2) indicated that reaches were significantly shallower prior to restoration across all stream reaches but showed no significant difference between treatment or control sites during any year. Average velocity did not differ significantly across years, but a significant treatment-by-year effect indicated that velocities were significantly greater in treatment reaches one year prior to restoration. Distance to fish cover was significantly lower one year prior to restoration but did not differ between control and treatment reaches. No other significant differences in habitat variables were detected.

\section{Distribution Shifts at the Channel Unit Scale}

Trout densities in HCU's are summarized for treatment sites, control sites, and across all sites for each study year (Table 3). Total trout abundances diminished over time (Table 4). Zeroinflation regression models described relationships between shifting trout densities and HCU, treatment, and year. The best model (i.e., lowest AICc) predicting total trout abundances at the channel-unit scale included effects of year, HCU, and treatment (i.e., restored or un-restored). 
Total abundance was significantly higher in 2011 (pre-restoration) and significantly lower in LOW than all other HCU types. The highest ranked model for predicting brook trout abundances included only HCU, and indicated that brook trout abundances were significantly lower in LOW and INT than in other HCU types. The best fit model for brown trout incorporated treatment, year, HCU, and an interaction effect between treatment and year (Table 5). There were significantly more brown trout in 2011 compared to post-restoration, and brown trout abundances were consistently greater in pools and lower in low gradient complexes. Brown trout densities were higher in pools than in other HCU's, and were significantly lower in low gradient complexes (Table 4). A significant year by treatment interaction indicated that brown trout densities were higher in control reaches in 2011 than in treatment reaches (Table 6).

The best fit model for rainbow trout contained year, HCU, and treatment. Rainbow trout densities were significantly higher in 2011 than in 2013 and 2015. Both low gradient complexes and intermediate grade complexes were associated with lower rainbow trout densities. No difference in densities between treatment and control sites were observed.

\section{Characteristics Influencing Trout Distribution}

No differences were found in average depth, velocity, and distance to fish cover between occupied and un-occupied natural pools, structure pools, low-gradient complexes, riffles, and intermediate-gradient complexes using one-way analysis of variance (Table 7). The number of channel units containing brook trout, brown trout, sympatric populations, and no trout for 2013, 2015, and both years combined are summarized in Table 8. The highest rates of sympatry occurred in intermediate gradient complexes, where brook and brown trout were both found in 13 of the 64 (33\%) habitat units occupied by trout. In contrast, both brook and brown trout 
occurred in 2 of $18(11 \%)$ natural pools containing trout, 2 of $15(13 \%)$ low gradient complexes containing trout and 1 of 7 (14\%) intermediate riffles containing trout. Intermediate gradient complexes contained the greatest percentage of habitat units occupied by trout, with trout occupying 39 out of 64 (64\%) habitat units. There were no sympatric uses of structure pools in both 2013 and 2015. Brook trout rates of occupancy were greatest in intermediate gradient complexes (32.8\% of 2013 and 2015 HCU's occupied), and were lowest in natural pools, where only 6 of 40 pools were occupied by only brook trout (15\%).

The best fit general linear mixed model comparing brook trout abundance to habitat variables included both distance to fish cover and depth as fixed effects (Table 9). No other model had $\triangle \mathrm{AICc}$ values less than two, and our top model had a weight of 0.659 . Both increasing distance to cover and greater depth were significantly correlated with lower brook trout abundances $(p<0.001$ and 0.027 , respectively). The top model for both rainbow and brown trout abundances contained only distance to fish cover as a fixed effect. Both rainbow and brown trout abundances were higher in channel units with greater fish cover. This relationship was not significant for rainbow trout $(p=0.19)$, but was significant for brown trout $(p=0.038)$. Finally, the best model selected for by AICc for predicting total trout abundance contained both distance to fish cover and depth as fixed effects, both of which were found to be significant ( $p=0.027$ and 0.001 , respectively).

\section{Discussion}

Trout displayed a clear selection in habitat channel usage. Neither brook, brown, nor rainbow trout were found in high densities in low gradient complexes, potentially due to higher water temperatures, habitat homogeneity, and poor conditions for drift feeding on benthic 
macroinvertebrates (Brittain and Eikeland 1988; Sinokrot and Stefan 1993; Gustafsson et al. 2013). These low gradient complexes exhibit a high degree of habitat homogeneity, which is often correlated to lower organism densities and diversity (Gorman and Karr 1978; Roni et al. 2008). Gustafsson et al. (2013) noted that homogenous low-gradient riffle habitat often contained lower densities of benthic macroinvertebrates due to lower levels of deposited organic material and decreased habitat availability. These reaches are also characterized by slow moving water, which will result in diminished macroinvertebrate drift densities and create less-optimal foraging conditions for stream fishes (Grossman et al. 2002).

Brook trout densities in riffles increased significantly from 2011 to 2013, during which time average velocities declined. Exceptionally high velocities may exclude fish from occupying habitat due to the increased energy expenditure to maintain stream position (Feldmeth and Jenkins 1973). Velocity is also one of the most important factors influencing feeding position in brown trout, potentially explaining the low densities of brown trout in these habitats in 2011. Shirvell and Dungey (1983) note that brown trout select habitats that possess an optimal combination of depth and velocity to maximize foraging ability while minimizing energy expenditure. Other species of salmonids have been routinely observed avoiding high-velocity habitat and seeking refuge in hydraulically sheltered areas near faster velocities to maximize net energy intake (McMahon and Hartman 1989, Rosenfeld and Boss 2001).

However, brook trout occupied higher gradient complexes at greater densities than brown and rainbow trout throughout all three years of the study, indicating that brook trout are selecting these habitats either because they are energetically efficient or because competition from nonnative salmonids, such as brown and rainbow trout, is forcing brook trout into marginalized habitat. Brook trout densities were typically highest in intermediate gradient riffle complexes. 
These HCU's are characterized as shallow reaches with high average velocities and little fish cover (Petty et al. 2001). While these areas generally lacked substantial fish cover, these habitats contained numerous small, hydraulically sheltered pockets in close proximity to faster velocity habitats, creating highly favorable feeding positions for feeding on drifting benthic macroinvebrates (Fausch and White 1981; Fausch 1984; Brittain and Eikeland 1988; Hill and Grossman 1993 Leung et al. 2009). The smaller size of brook trout in comparison to brown and rainbow reduces energy requirements for holding positions in faster velocities and allows them to occupy small, hydraulically sheltered areas that are unavailable to larger brown and rainbow trout (Rosenfeld and Boss 2001), thus making these areas profitable foraging habitats.

While high velocity complexes may be suitable for brook trout as feeding habitat, longterm occupancy of these habitats could be energetically unfavorable (Fausch 1984). Potential exclusion from energetically efficient resting habitat by exotic rainbow and brown trout could force brook trout into these habitats for extended period of time, leading to diminished rates of survival and fecundity (Rosenfeld and Boss 2001). Interspecific competition and dominance hierarchies in fish communities can have a significant influence on foraging behavior, location within streams, and activity levels of many fish species (Nakano 1995; Petty and Grossman 2004; Petty and Grossman 2010). Brook trout in Shavers Fork are typically significantly smaller than brown trout at maturity, and thus are less likely to out-compete brown trout for optimum habitat (Nakano 1995). Fausch and White (1981) found that brook trout occupied resting positions with higher velocities in the presence of brown trout than when brown trout were absent due to competitive exclusion from more energetically favorable habitats. Similar interaction between brown and brook trout in Shaver's Fork may be forcing brook trout into riffles and intermediate-gradient habitat. 
Brown trout occupied pools at a greater density than brook trout in 2011 and 2013 and at nearly equal densities in 2015 , despite having much lower total densities than brook trout. Natural pools exhibited a significantly lower distance to fish cover than other habitat types, providing concealment from natural predators, additional foraging opportunities, and shelter from higher velocities (Cunjak and Power1986; McMahon and Hartman 1989). In headwater streams, brook trout often prefer pool habitat over riffles (Flebbe 1999), thus it is expected that brook trout would prefer these habitats in the upper reaches of Shavers Fork. However, previous studies have found that brown trout competitively exclude of brook trout in larger stream reaches, which could indicate that brown trout occupancy of pools could limit brook trout use of these habitats (Fausch and White 1981; Oglund et al. 2008; Butryn et al. 2013).

In addition to having a competitive advantage due to larger size, brown trout are able to adapt to higher stream temperatures than brook trout, and thus maintain a competitive advantage throughout the summer. Taniguchi et al. (1998) found that brown trout competitively dominant over brook trout once ambient stream temperatures exceeded $22{ }^{\circ} \mathrm{C}$, and could maintain normal feeding behavior up to $26^{\circ} \mathrm{C}$. Normal feeding behavior ceased in brook trout once temperatures reached $24^{\circ}$. Summer stream temperatures in Shavers Fork regularly exceed $22^{\circ} \mathrm{C}$, but rarely exceed $26{ }^{\circ} \mathrm{C}$ (USGS temperature data), thus brown trout could easily be competitively excluding brook trout from preferred habitat. The importance of these larger and deeper pools may be heightened during summer when they are necessary to the survival of brook trout within the main stem of Shavers Fork due to their ability to act as thermal refugia during summer extremes (Petty et al. 2012).

Brook trout were the first species to move significantly into newly created structure pools. Moreover, they occupied these pools at densities more than four times greater than 
rainbow trout in 2013and brown trout in 2015 and twice the density of rainbow trout in 2015. Interestingly, brown trout were not found within structure pools one year after restoration, while brook trout densities within these newly created habitats were greater than their densities in all other habitat channel units (with the exception of intermediate-gradient riffles. Numerous studies have shown that high mobility in brook trout (Hartman and Logan 2010; Petty et al. 2012). It is likely that the highly mobile nature of this species allowed them to find and occupy newly created pools quicker than brown and rainbow trout. Cumulative movement, home range, and daily movement are negatively related to fish size, indicating that smaller fish may be forced out of optimal habitats by larger, more dominant individuals (Symons 1971; Nakano 1995). If brown trout are showing competitive dominance in Shavers Fork, then they would be expected to have lower dispersal rates because they would be able to maintain position within optimal habitats. Exclusion of brook trout from optimal habitats would result in greater variability in movement to search for more suitable habitat, which would increase their likelihood of discovering and occupying these newly created habitats prior to brown trout. Radio telemetry data previously collected within the study sites at Shavers Fork indicated that brown trout exhibited relatively sedentary behavior when compared to brook trout, often taking up extended residence in large, deep pools with a significant amount of cover (Hansbarger 2005). This type of behavior is expected from dominant fish within a system.

While brown trout show limited movement patterns in Shavers, brook trout have displayed highly variable movement patterns in previous studies. Hartman and Logan (2010) found that brook trout home ranges composed of an average of 450 meters of stream, with some individuals accumulating $2800 \mathrm{~m}$ of total movement during the summer tracking season. Brown trout also display highly variable movement patterns during summer months, but often return to 
a few selected home sites. Clapp et al. (1990) found that brown trout movement during spring and summer periods was significantly less than their movements during autumn and winter. Brown trout appeared to feed mostly at night, and would return to specific home sites during the day time. Often, their preferred day time locations were deep, slow moving pools with significant cover, comparable to the natural pools found in Shavers Fork.

Low rates of sympatry between brook and brown trout within pools also indicate potential competitive exclusion. Only 18 out of the 83 channel units $(21.7 \% \%)$ that were occupied by trout in 2013 and 2015 contained both brook trout and brown trout. In pools specifically, only ten contained brown trout only, while six contained only brook trout, but only $2(11.1 \%$ of occupied pools) contained sympatric populations. In intermediate gradient units, sympatry occurred in $33 \%$ of the units containing trout. Sympatry was not observed within structure pools in either 2013 or 2015. Greater rates of sympatry are expected in intermediate gradient complexes because these units are typically longer than pools and are often divided by riffle areas in numerous sub-habitats, thus making them more complex and minimizing competition for resources (Almany 2004). In contrast, units classified as pools are typically unified into one homogenous unit. Thus, a brook trout in an intermediate grade habitat could occupy a sub-habitat in close proximity to a brown trout but be free from competitive interactions due to visual isolation, whereas a brook trout could occupy a space the exact same distance from a brown trout within a pool and be exposed to competitive interactions due to fewer available microhabitats and greater visibility (Fausch and White 1986). Observation of fine-scale microhabitat use of brook and brown trout within both natural pool and created structure pool habitats is needed to determine preferred habitat selection by each of these species 
to conclude if competition exists for optimal habitat locations. Fine-scale microhabitat data should also be collected to better quantify habitat availability.

Distance to fish cover was strongly correlated to higher fish densities, whereas greater distances to cover resulted in lower trout densities. Numerous studies have noted that increased cover is often associated with increased salmonid densities (Wilzbach 1985; Flebbe 1999; Sweka and Hartman 2006). Abundant fish cover is typically indicative of significant habitat heterogeneity within streams, which provides a greater diversity and abundance of habitats (Gorman and Karr 1978). Instream cover provides protection from predation (Savino and Stein 1989), increased foraging opportunities (Harmon 1986; Gustafsson et al. 2013), and shelter from stream current (Shirvell 1990). While better cover can protect species from predation, large predatory fish have been observed occupying areas of greater cover in order to ambush prey and maximize foraging success (Savino and Stein 1989). Habitat complexity also increases the retention of organic matter within streams, leading to a rise in benthic macroinvertebrate abundances (Smokorowski and Pratt 2007). Removing cover from within streams can lead to reduced fish abundances diminished population size-structure (Copp and Bennetts 1996).

Variability in the consistency of backpack electrofishing capture rates would impact the results of this study; however, the results of triple pass depletion method indicate that capture rates were consistent across years. Surveys were conducted by a different team of technicians and graduate students each year, and environmental conditions, such as level of cloudiness, stream flow, and turbidity, changed annually, but changes in these variables appears to have minimally impact the success of first-pass capture probabilities.

A goal of the restoration project on the Shavers Fork was to increase total trout abundances, especially wild brook trout. Many restoration studies aim to increase trout 
population by providing increased habitat to relieve density dependent regulation (Petty et al. 2014; Belk et al. 2016). The results of this study suggest that total trout abundance were significantly greater prior to restoration. A large portion of this reduction can be explained by the rapid decline in rainbow trout numbers. Prior to restoration, rainbow trout were stocked through the study reaches via a rail stocking program overseen by the West Virginia Division of Natural Resources. However, to better determine the impacts of restoration on native species, rainbow trout stockings were eliminated from all but the most down-stream study reach, thus resulting in fewer rainbow trout throughout the study post-restoration.

Brown trout densities showed steady declines throughout the study period, and brook trout densities remained stable. Hunt (1988) found a similar trend while evaluating restoration projects in Wisconsin, noting that brook trout densities increased after restoration in a majority of the streams studied, but brown trout densities remained relatively stable. In this study, brown trout densities did not significantly increase after restoration, but fish of harvestable size were more numerous throughout the study reaches. These larger brown trout would be a greater target for anglers, and thus angling pressure is likely a substantial factor in the decline of brown trout during this study period. Brown trout densities were significantly greater in control reaches prior to restoration, but shifted into restored reaches post-restoration. This shift in distribution was coupled with substantially declining brown trout populations, which suggests that brown trout were being concentrated into newly created pools habitats, but were then being removed via angling. These newly created structure pools were visually appealing targets for anglers. Several anglers were observed fishing in these pools during the sampling periods, and at least one radiotelemetry tagged brown trout was reported as harvested by an angler. Angling was allowed to continue in Shavers Fork before, during, and after completion of the restoration project. Hunt 
(1988) found that angler use and catch rates increased in several reaches after habitat restoration projects were completed in Wisconsin streams, indicating that these sites became targets for anglers and possibly concentrated trout around created structures

Brook trout densities increased in study pools post-restoration, yet their densities remained relatively consistent across all channel unit types, further suggesting that these structures may act as an attractive sink and concentrate trout. Reef restoration efforts have yielded similar results, where target populations increase within the targeted area immediately after the construction of new artificial reef habitats, but total production within the system does not substantially increase (Bohnsack 1989). Artificial reefs often act as attractants, initially concentrating large numbers of fish from nearby marginal habitats (Lowry et al. 2014). However, concentration of many reef fish species around these artificial structures lends to increased harvest mortality rates, and leads to stagnant or declining populations trends (Bohnsack 1989;Piraino and Szedlmayer 2014). Artificial structures created in cold water stream environments potentially act to attract fish in a similar manner. These newly created structures provide many of the same benefits as artificial reefs: additional cover, foraging habitat, and complexity (Pickering and Whitmarsh 1997). However, just like many artificial reefs, these structures may serve to concentrate fish populations, making them more susceptible to harvests. While these structures may some relief from limiting habitat constraints, the increased harvest resulting from the concentration of trout into these limited confined areas may negate any additional benefits these created pools may confer on the overall population structure.

Further population growth in the main stem of Shavers Fork may be limited by factors that were not addressed in this current study (i.e. temperature). Daily maximum stream temperatures in Shavers Fork often exceed the range for optimum metabolic rate of brook trout, 
which ranges between 10 and $19{ }^{\circ} \mathrm{C}$ (Hartman and Sweka 2001). Consequently, brook trout densities in the main stem of Shavers Fork are limited by the availability of thermal refugia (Petty et al. 2014). Thermal refugia provide habitat with temperatures consistently cooler than ambient stream temperatures. While larger, fluvial habitats are often highly productive, the use of these habitats by stenothermal organisms, such as most salmonids, is highly dependent on the number and area of thermal refugia available for occupancy.

\section{Conclusions}

Habitat shifts appear to have occurred after the multi-scale restoration project completed at Shavers Fork. All three trout species occupied newly created structure pools within three years of implementation, with brook trout densities shifting into these new pools most quickly. Broad declines in brown trout populations and shifts from control to treatment reaches suggests newly constructed pools may be acting as attractive sinks through increases angling pressure. Sustained brook trout populations may be explained by their high mobility and broader metapopulation dynamics through the watershed (Huntsman and Petty 2014). More time is likely needed to determine if habitat restoration can have long-term effects on trout population densities (Hartman and Sweka 2006). Further research is needed to determine the effect of angling on trout resposnes to this and other restoration activities.

Further study is also needed to determine factors most limiting population growth within the main stem of Shavers Fork. Specifically, habitat data collected at the macroscale do not illuminate factors influencing trout occupancy of select locations within channel units. Detailed microhabitat use by brook, brown, and rainbow trout within both restored and natural channel units is needed to determine preferred habitat in greater detail, and to discern if overlap in habitat preferences exists between these species. 


\section{Literature Cited}

Allen M.R., D.J. Frame, C. Huntingford, C.D. Jones, J.A. Lowe, M. Meinshausen, et al. 2009. Warming caused by cumulative carbon emissions towards the trillionth tonne. Nature 458:1163-1166.

Almany, G.R. 2004. Does increased habitat complexity reduce predation and competition in coral reef fish assemblages? Oikos 106:275-284.

Anderson, G.B., M.C. Freeman, B.J. Freeman, C.A. Straight, M.M. Hagler, and J.T. Peterson. 2012. Dealing with uncertainty when assessing fish passage through culvert road crossings. Environmental Management 50:462-477.

Anglin, Z.W. and GD Grossman. 2013. Microhabitat use by southern brook trout (Salvelinis fontinalis) in a headwater North Carolina stream. Ecology of Freshwater Fish 22:567577.

Aunins, A.W., J.T. Petty, T.L. King, M. Schilz, and P.M. Mazik. 2015. River mainstem thermal regimes influence population structuring within an Appalachian brook trout population. Conservation Genetics 16:15-29.

Barton, K. 2015. MuMIn: Multi-Model Inference. R package version 1.13.4. http://CRAN.Rproject.org/package=MuMIn.

Belk, M.C. E.J. Billman. C. Ellsworht. And B.R. McMillan. 2016. Does habitat restoration increase the coexistence of native stream fishes with introduced brown trout: a case study on the Middle Provo River, Utah, USA. Water 8:121. Doi:10.3390/w8040121.

Bohnsack, J.A. 1989. Are the high densities of the fishes at artificial reefs the result of habitat limitation or behavioral preferences? Bulletin of Marine Science 44:631-645. 
Bond, N.R. and P.S. Lake. 2003. Local habitat restoration in streams: the constraints on the effectiveness of restoration for stream biota. Ecological Management and Restoration 4:193-198.

Brittain, J.E. and T.J. Eiekland. 1988. Invertebrate drift: a review. Hydrobiologia 166:77-93.

Butryn, R.S. D.L Parrish, and D.M. Rizzo. 2013. Summer stream temperatures metrics for predicting brook trout (Salvelinus fontinalis) distribution in streams. Hydrobiologia 703:47-57.

Cade. B.S. 2015. Model averaging and muddled multi-model inferences. Ecology 96:2370-2382. Fox, J. and S. Weisberg. 2011. An $\{\mathrm{R}\}$ Companion to Applied Regression, Second Edition. Thousand Oaks CA: Sage.

Clapp, D.F., R.D. Clark, and J.S. Diana. 1990. Range, activity, and habitat of large, free-ranging brown trout in a Michigan stream. Transactions of the American Fisheries Society 119:1022-1034.

Clark, M.E. and K.A. Rose. 1997. Factors affecting competitive dominance of rainbow trout over brook trout in southern Appalachian streams: implications of an individual-based model. Transactions of the American Fisheries Society, 126:1-20.

Comte, L., L. Buisson, M. Daufresne, and G. Grenouillet. 2013. Climate-induced changes in the distribution of freshwater fish: observed and predicted trends. Freshwater Biology $58: 625-639$.

Copp, G.H. and T.A. Bennetts. 1996. Short-term effects of removing riparian vegetation and instream cover on barbell and other fish population in a stretch of English chalk stream. Folia Zoologica 45:283-288. 
Crowl, T.A.,T.O. Crist, R.R. Parmenter, G. Belovsky, and A.E. Lugo. 2008. The spread of invasive species and infectious disease as drivers of ecosystem change. Frontiers in Ecology and the Environment 6:238-246.

Cunjak, R.A. and G. Power. Winter Habitat Utilization by stream resident brook trout Salvelinus fontinalis) and Brown Trout (Salmo trutta). 1986. Canadian Journal of Fisheries and Aquatic Sciences. 43:1970-981.

Curry, R. A., and W. S. MacNeill. 2004. Population-level responses to sediment during early life in brook trout. Journal of the North American Benthological Society 23:140-150.

Dewald, L. and M.A. Wilzbach. 1992. Interactions between native brook trout and hatchery brown trout: effects on habitat use, feeding, and growth. Transactions of the American Fisheries Society 121:287-296.

DeWeber, J.T. and T. Wagner. 2015. Predicting brook trout occurrence in stream reaches throughout their native range in the eastern United States. Transactions of the American Fisheries Society 144:11-24.

Dunham, J.B., D. S. Pilliod and M.K. Young. 2004. Assessing the Consequences of Nonnative Trout in Headwater Ecosystems in Western North America. Fisheries 29:18-26.

Eaton, J.G., J.H. McCormick, B.E. Goodno, D.G. Brien, H.G. Stefany, M. Hondzo, and R.M. Scheller. 1995. A field-based system for estimating fish temperature tolerances. Fisheries 20:10-18.

Fausch, K.D. an R.J. White. 1981. Competition between brook trout Salvelinus fontinalis) and Brown Trout (Salmo trutta) for Positions in a Michigan Stream. Canadian Journal of Fisheries and Aquatic Sciences. 38:1220-1227. 
Fausch, K. D. 1984. Profitable stream position for salmonids: relating specific growth rates to net energy gain. Canadian Journal of Zoology 62:441-451.

Fausch, K.D. and R.J. White. 1986. Competition among juveniles of coho salmon, brook trout, and brown trout in a laboratory stream and implications for Great Lakes Tributaries. Transactions of the American Fisheries Society 115:363-381.

Feldmeth, C.R. and T.M. Jenkins. 1972. An estimate of energy expenditure by rainbow trout (Salmo gairdneri) in a small mountain stream. Journal of the Fisheries Research Board of Canada 30:1755-1759.

Flebbe, P.A. 1999 Trout use of woody debris and habitat in Wine Spring, North Carolina. Forest Ecology and Management 114:367-376.

Gorman, O.T. and J.R. Karr. 1978. Habitat structure and stream fish communities. Ecology 59:507-515.

Grossman, G.D., P.A. Rincon, M.D. Farr, R.E. Ratakczak. 2002. A new optimal foraging model predicts habitat use by drift-feeding stream minnows. Ecology of Freshwater Fish 11:210.

Gustafsson, S., M. Österling, J. Skurdal, L.D. Schneider, and O. Calles. 2013. Macroinvertebrate colonization of a nature-like fishway: the effects of adding habitat heterogeneity. Ecological Engineering 61:345-353.

Hansbarger, J.L. 2005. Trout movement and habitat use in the upper Shavers Fork of the Cheat River, West Virginia. Morgantown, WV: West Virginia University. M.S. thesis. Harmon, M.E., J. F. Franklin, F.J. Swanson, P. Sollins, S. V. Gregory, J. D. Lattin, N. H. Anderson et al. 1986. Ecology of coarse woody debris in temperate ecosystems. Advances in ecological research 15:133-302. 
Hartman, K.J. and J.A. Sweka. 2001. Development of a bioenergetics model for Appalachian brook trout. Proceedings of the Annual conference of Southeast Association of Fish and Wildlife Agencies 55:38-51.

Hartman, K.J. and M.N. Logan. 2010. Movement and habitat use by transplanted adult brook trout in an Appalachian headwater stream. Northeastern Naturalist 17:357-372.

Hill, J. and G.D. Grossman. 1993. An energetic model of microhabitat use for rainbow trout and rosyside dace. Ecology 74:685-698.

Hudy, M., D. M. Downey, and D. W. Bowman. 2000. Successful restoration of an acidified native brook trout stream through mitigation with limestone sand. North American Journal of Fisheries Management 20:453-466.

Hudy, M., T.M. Thieling, N. Gillespie, and E.P. Smith. 2008. Distribution, status and land use characteristics of subwatersheds within the native range of brook trout in the eastern native range of brook trout in the Eastern United States. North American Journal of Fisheries Management 28:1069-1085.

Huntsman, B.M. and J.T. Petty. 2014. Density-dependent regulation of brook trout population dynamics along a core-periphery distribution gradient in a central Appalachian watershed. PLOS One 9: e91673

Isaak, D.J. and B.E. Rieman. 2013. Stream isotherm shifts from climate change and implication for distributions of ectothermic organisms. Global Change Biology 19:742-751

Kanno, Y., B.H. Letcher, A.L. Rosner, K.P. O’Neil, and K.H. Nislow. 2015a. Environmental factors affecting brook trout occurrence in headwater stream segments. Transactions of the American Fisheries Society 144:373-382. 
Kanno, Y., K.C. Pregler, N.P. Hitt, B.H. Lether, D.L. Hocking, and J.E.B. Wofford. 2015 b. Seasonal temperature and precipitation regulate brook trout young-of-the-year abundance and population dynamics. Freshwater Biology doi:10.1111/fwb.12682.

Keleher, C.J. and F.J. Rahel. 1996. Thermal limits to salmonid distribution in the Rocky Mountain Region and potential habitat loss due to global warming: and geographic information system approach. Transactions of the American Fisheries Society 125:1-13.

Larson, G.L. and S.E. Moore. 1985. Encroachment of exotic rainbow trout into stream populations of native brook trout in the southern Appalachian Mountains. Transactions of the American Fisheries Society, 114:195-203.

Larson, M.G., D.B. Booth, and S.A. Morley. 2001. Effectiveness of large woody debris in stream rehabilitation projects in urban basins. Ecological engineering 18:211-226.

Lepori Fl., D. Palm, E. Brannas, and B. Malmqvist. 2005. Does restoration of structural heterogeneity in stream enhance fish and macroinvertebrate diversity? Ecological Applications 15:2060-2071.

Leung, E.S., J.S. Rosenfeld, J and .R. Bernhardt. Habitat effects on invertebrate drift in a small trout stream: implications for prey availability to drift-feeding fish. Hydrobiologia 623:113-125.

Lowry, M.B., T.M. Glasby, C.A. Boys, I. Suthers, and M. Gregson. 2014. Response of fish communities to the deployment of estuarine artificial reefs for fisheries enhancement. Fisheries Ecology and Management 21:42-56.

Magoulick, D.D., M.A. Wilzbach. 1998. Effect of temperature and macrohabitat on interspecific aggression, foraging success, and growth of brook trout and rainbow trout pairs in laboratory systems. Transactions of the American Fisheries Society 127:708-717. 
McClurg, S.E, J.T Petty, P.M. Mazik, and J.L. Clayton. Stream ecosystem response to limestone treatment in acid impacted watersheds of the Allegheny Plateau. Ecological Applications 17:1087-1104.

McDonnell, T. C., M. R. Sloat, T. J. Sullivan, C. A. Dolloff, P. F. Hessburg, N. A. Povak, W. A. Jackson, and C. Sams. 2015. Downstream Warming and Headwater Acidity May Diminish Coldwater Habitat in Southern Appalachian Mountain Streams. PloS one 10: e0134757.

McKenna, J.E., M.T. Slattery, K.M. Clifford. 2013. Broad-scale patterns of brook trout responses to introduced brown trout in New York. North American Journal of Fisheries Management 33:1221-1235.

Nakano, S. 1995. Individual differences in resource use, growth, and emigration under the influences of a dominance hierarchy in fluvial red-spotted masu salmon in a natural habitat. Journal of Animal Ecology 64:75-84.

Nielsen, J.L., T.E. Lisle, V. Ozaki. 1994. Thermally stratified pools and their use by steelhead in a Northern California Stream. Transactions of the American Fisheries Society 123:613626.

Ohlund, G., F Nordwall, E. Degerman, T. Eriksson. 2008. Life history and large-scale habitat use of brown trout (Salmo trutta) and brook trout (Salvelinus fontanalis)- implications for species replacement patterns. Canadian Journal of Aquatic Science 65:633-644.

Oksanen, J., F. G. Blanchet, R. Kindt, P. Legendre, P. R. Minchin, R. B. O'Hara, G. L. Simpson, P. Solymos, M. H. Stevens and H. Wagner 2015. vegan: Community Ecology Package. $\mathrm{R}$ package version 2.2-1. http://CRAN.R-project.org/package=vegan. 
Petty, J.T., P.J. Lamothe, and P.M. Mazik. 2005. Spatial and seasonal dynamics of brook trout populations inhabiting a central Appalachian watershed. Transactions of the American Fisheries Society 134:572-587.

Petty, J.T., J.L. Hansbarger, B.L. Huntsman, and P.M. Mazik. 2012. Brook trout movement in response to temperature, flow, and thermal refugia within a complex Appalachian riverscape. Transactions of the American Fisheries Society 141:1060-1073.

Petty, J. T. and E.P. Merriam. 2012. Brook Trout Restoration. Nature Education Knowledge 3:17.

Petty, J.T., D. Thorne, B.L. Huntsman, and P.M. Mazik. 2014. The temperature productivity squeeze: constraints on brook trout growth along an Appalachian River continuum. Hydrobiologia727:151-166.

Pickering, H., and D. Whitmarsh. 1997. Artificial reefs and fisheries exploitation: a review of the 'attraction versus production' debate, the influence of design and its significance for policy. Fisheries Research 31:39-59.

Pinheiro J., D. Bates, S. DebRoy, D. Sarkar and R Core Team. 2017. nlme: Linear and Nonlinear Mixed Effects Models. R package version 3.1-131, https://CRAN.Rproject.org/package=nlme.

Piraino, M. N. and S.T. Szedlmayer. 2014.Fine-scale movements and homerange of red snapper around artificial reefs in the northern Gulf of Mexico. Transactions of the American Fisheries Society 143:988-998

Poplar-Jeffers. I.O, J.T. Petty, J.T. Anderson, S.J. Kite, M.P. Strager, and R.H. Fortney. 2009. Culvert replacement and stream habitat restoration: implications from brook trout management in an Appalachian watershed, U.S.A.. Restoration Ecology 17:404-413. 
R Core Team (2013). R: A language and environment for statistical computing. R Foundation for statistical Computing, Vienna, Austria. URL http://www.R-project.org/.

Rahel, F.J. and J.D. Olden. 2008. Assessing the effects of climate change on aquatic invasive species. Conservation Biology 22:521-533.

Roberts. D.W. 2013. labdsv: Ordination and Multivariate Analysis for Ecology. R package version 1.6-1. http://CRAN.R-project.org/package=labdsv.

Rosenfeld, J.S. and S. Boss. Fitness consequences of habitat use for juvenile cutthroat trout: energetic costs and benefits in pools and riffles. Canadian Journal of Fisheries and Aquatic Sciences 58:585-593.

Savino, J.F. and R.A. Stein. 1989. Behavior of fish predators and their prey: habitat choice between open water and dense vegetation. Environmental Biology of Fishes 4:287-293.

Shirvell, C.S. 1990. Role of instream rootwads as juvenile coho salmon (Ohcorhynchus kisutch) and steelhead trout (O. mykiss) cover habitat under varying stream flows. Canadian Journal of Fisheries and Aquatic Sciences 47:852-861.

Shirvell, C.S. and R.G. Dungey. 1983. Microhabitats chosen by brown trout for feeding and spawning in rivers. Transactions of the American Fisheries Society 112:355-367.

Sinokrot, B.A, and H.G. Stefan. 1993. Stream temperature dynamics: measurements and modeling. Water Resources Research 29:2299-2312.

Skaug, H., D. Fournier, and A. Nielsen. 2006. glmmADMB: generalized linear mixed models using AD Model Builder. R package version 0.3.

Smokorowski, K. and T.C. Pratt. 2007. 2007. Effects of a change in physical structure and cover on fish and fish habitat in freshwater ecosystems-a review and meta-analysis. Environmental Reviews 15:15-41. 
Stranko, S.A., R.H. Hilderbrand, R.P. Morgan, M.W. Staley, A.J. Becker, A. RosenberryLincoln, E.S. Perry, and P.T. Jacobson. 2008. Brook trout declines with land cover and temperature changes in Maryland. North American Journal of Fisheries Management 28:1223-1232.

Sweka, J.A. and K.J. Hartman. 2006. Effects of large woody debris addition on stream habitat and brook trout populations in Appalachian streams. Hydrobiologia, 559:363-378.

Symons, P.E.K. 1971. Adjustment to population density to food available food by juvenile Atlantic Salmon. Journal of Animal Ecology 40:569-587.

Taniguichi, Y., D. C. Novinger, F. J. Rahel, and K. Gerow. 1998. Temperature mediation of competitive interactions among three fish species, brook trout, brown trout, and creek chub, that replace each other along longitudinal stream gradients. Canadian Journal of Fisheries and Aquatic Sciences 55:1894-1901.

Wagner, T., J.T. Deweber, J. Detar, and J.A. Sweka. 2013. Landscape-scale evaluation of asymmetric interactions between brown trout and brook trout using two-species occupancy models. Transactions of the American Fisheries Society 142:353-361.

Waters, T.F. 1983. Replacement of brook trout by brown trout over 15 years in a Minnesota stream: production and abundance. Transactions of the American Fisheries Society 112:137-146.

Wilzbach, M.A. 1985. Relative roles of food abundance and cover in determining the habitat distribution of stream-dwelling cutthroat trout (Salmo clarki). Canadian Journal of Fisheries and Aquatic Sciences 42:1668-1672.

Xu, C., B. H. Letcher \& K. H. Nislow, 2010. Context-specific influence of water temperature on brook trout growth rates in the field. Freshwater Biology 55: 2253-2264. 
Xu, L. A.D. Paterson, W. Turpin, and W. Xu. 2015. Assessment and Selection of competing models for zero-inflated microbiome data. PlosOne:DOI:10.1371/journal.pone.0129606

Zeileis, A., C. Kleiber, and S. Jackman. 2008. Regression Models for Count Data in R. Journal of Statistical Software 27(8). 
Tables and Figures

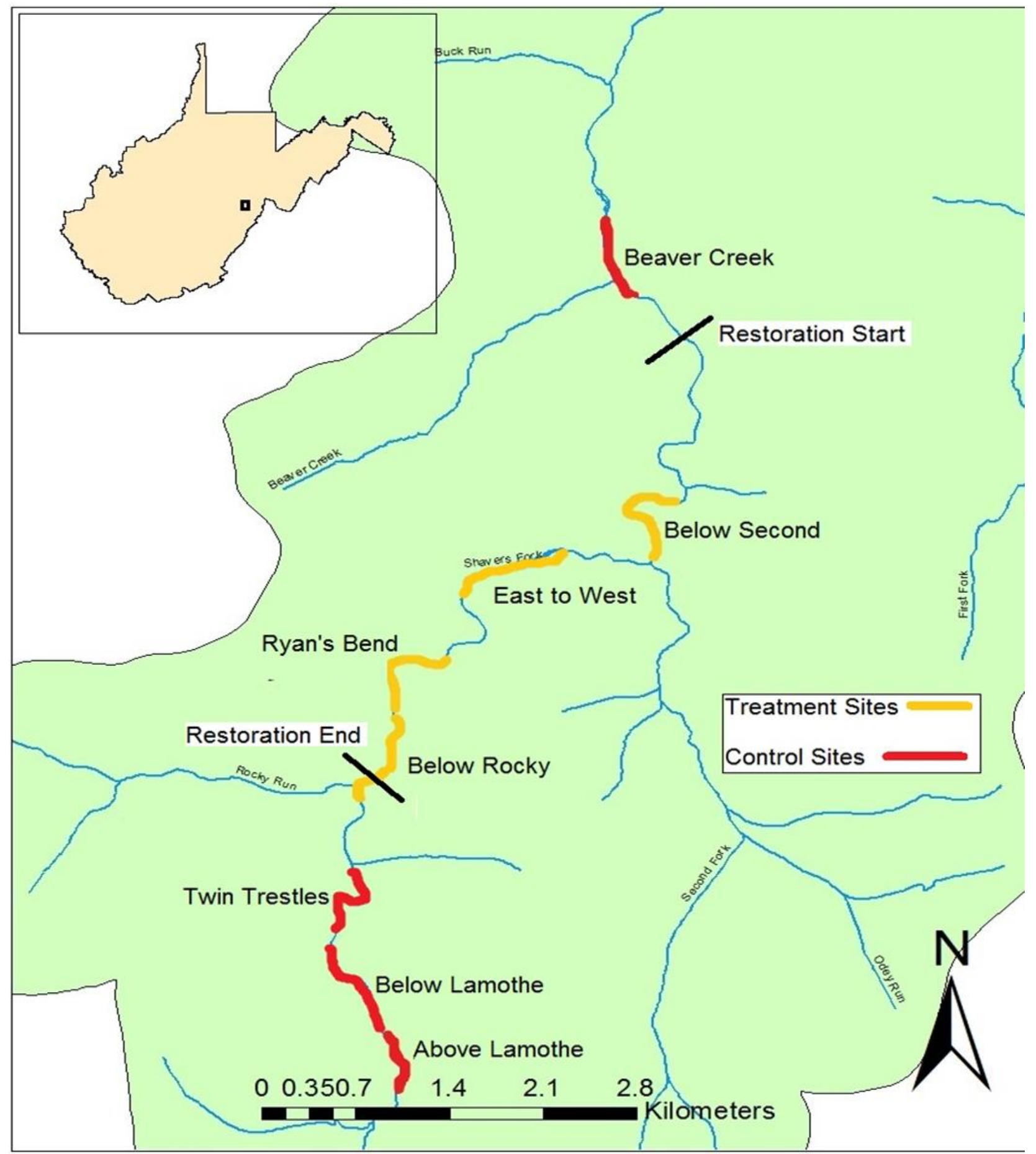

Figure 1: The Upper Shavers Fork Watershed. Control sites (Beaver Creek, Twin Trestles, Below Lamothe and Above Lamothe) are highlighted in red, while treatment sites (Below Second, East to West, Ryan's Bend and Below Rocky) are highlighted in yellow. 
Table 1: Summary of habitat variables across HCU's for both control and treatment sites across years. IGR represents intermediate gradient riffles, INT represent intermediate gradient complexes, LOW represents low gradient complexes, and NAT represents natural pools, and STR represents structure pools. --- represents years or reaches without structure pools.

\begin{tabular}{|c|c|c|c|c|c|c|}
\hline \multirow{2}{*}{$\frac{\mathrm{HCU}}{\text { Variables }}$} & \multicolumn{2}{|c|}{2011} & \multicolumn{2}{|c|}{2013} & \multicolumn{2}{|c|}{2015} \\
\hline & Treatment & Control & Treatment & Control & Treatment & Control \\
\hline \multicolumn{7}{|l|}{ IGR } \\
\hline Depth $(\mathrm{cm})$ & $20.44(8.53)$ & $17.84(6.60)$ & $23.46(8.32)$ & $19.96(6.50)$ & 21.75(11.12) & $17.95(6.35)$ \\
\hline Avg. Velocity (m/s) & $0.82(0.49)$ & $0.34(0.24)$ & $0.39(0.18)$ & $0.31(0.17)$ & $0.26(0.15)$ & $0.40(0.18)$ \\
\hline Distance to cover (m) & $4.50(4.40)$ & $5.69(4.65)$ & $19.96(13.48)$ & $19.89(22.17)$ & $13.08(9.96)$ & $11.12(8.10)$ \\
\hline \multicolumn{7}{|l|}{ INT } \\
\hline Depth $(\mathrm{cm})$ & $19.86(6.91)$ & $22.04(9.85)$ & $24.09(8.46)$ & $25.42(10.83)$ & $22.21(9.01)$ & $23.12(8.42)$ \\
\hline Avg. Velocity $(\mathrm{m} / \mathrm{s})$ & $0.43(0.28)$ & $0.31(0.25)$ & $0.30(0.16)$ & $0.26(0.17)$ & $0.27(0.17)$ & $0.25(0.16)$ \\
\hline Distance to cover (m) & $6.78(6.48)$ & $13.40(17.54$ & $25.32(28.07)$ & $32.49(41.83)$ & $19.23(17.48)$ & $30.45(43.28)$ \\
\hline \multicolumn{7}{|l|}{ LOW } \\
\hline Depth $(\mathrm{cm})$ & $21.76(9.20)$ & $25.16(10.02$ & $31.78(14.83)$ & 28.65(11.65) & $30.36(12.92)$ & $22.55(11.06)$ \\
\hline Avg. Velocity $(\mathrm{m} / \mathrm{s})$ & $0.25(0.19)$ & $0.35(0.37)$ & $0.11(0.07)$ & $0.21(0.14)$ & $0.14(0.11)$ & $0.15(0.10)$ \\
\hline Distance to cover (m) & $8.31(8.62)$ & $12.47(9.44)$ & $32.92(34.17)$ & $29.69(37.51)$ & $20.37(16.72)$ & $27.23(28.5)$ \\
\hline \multicolumn{7}{|l|}{ NAT } \\
\hline Depth $(\mathrm{cm})$ & $38.88(15.22)$ & $43.48(21.30$ & $47.74(25.09)$ & $48.14(24.65)$ & $46.60(22.31)$ & $54.65(24.21)$ \\
\hline Avg. Velocity (m/s) & $0.31(0.26)$ & $0.26(0.21)$ & $0.18(0.19)$ & $0.15(0.11)$ & $0.09(0.08)$ & $0.13(0.13)$ \\
\hline Distance to cover (m) & $2.66(3.30)$ & $6.20(10.36)$ & $15.72(27.20)$ & $4.89(4.65)$ & $11.77(9.98)$ & $9.19(11.48)$ \\
\hline \multicolumn{7}{|l|}{ STR } \\
\hline Depth $(\mathrm{cm})$ & --- & --- & $43.00(20.88)$ & --- & $49.68(38.10)$ & --- \\
\hline Avg. Velocity $(\mathrm{m} / \mathrm{s})$ & --- & --- & $0.14(0.13)$ & --- & $0.10(0.12)$ & --- \\
\hline Distance to cover $(\mathrm{m})$ & --- & --- & $15.72(27.2)$ & --- & $11.23(10.34)$ & --- \\
\hline
\end{tabular}


Table 2: Results of linear mixed models evaluating differences in depth (DEP), average velocity (AVG) and distance to fish cover (DFC) across years and treatments sites. A treatment-by-year fixed effect was included in the models to determine if habitat parameters differed between treatment and control sites within years. $\mathrm{P}$ values are shown. * indicates $\mathrm{p}$-values between 0.5 and 0.01 , ** indicates values between 0.001 and 0.01 , and $* * *$ indicates p-values $<0.001$.

\begin{tabular}{|c|c|c|c|}
\hline Variables & & & \\
\hline Parameters & Estimate & Standard Error & p-value \\
\hline \multicolumn{4}{|l|}{ Depth } \\
\hline Intercept & 3.46 & 0.17 & $<0.001 * * *$ \\
\hline Treatment & 0.05 & 0.06 & 0.33 \\
\hline 2011 & -0.20 & 0.06 & $<0.001 * * *$ \\
\hline 2015 & -0.09 & 0.06 & 0.12 \\
\hline Treatment:2011 & -0.03 & 0.08 & 0.71 \\
\hline Treatment:2015 & -0.01 & 0.08 & 0.86 \\
\hline \multicolumn{4}{|l|}{ Average Velocity } \\
\hline Intercept & -1.68 & 0.21 & $<0.001 * * *$ \\
\hline Treatment & -0.01 & 0.10 & 0.91 \\
\hline 2011 & 0.16 & 0.10 & 0.12 \\
\hline 2015 & -0.17 & 0.10 & 0.11 \\
\hline Treatment:2011 & 0.54 & 0.15 & $<0.001 * * *$ \\
\hline Treatment:2015 & -0.00 & 0.15 & 0.99 \\
\hline \multicolumn{4}{|l|}{ Distance to Fish Cover } \\
\hline Intercept & 2.40 & 0.23 & $<0.001 * * *$ \\
\hline Treatment & -0.09 & 0.16 & 0.55 \\
\hline 2011 & -0.55 & 0.15 & $<0.001$ \\
\hline 2015 & 0.05 & 0.16 & 0.74 \\
\hline Treatment:2011 & -0.11 & 0.22 & 0.63 \\
\hline Treatment:2015 & 0.24 & 0.22 & 0.28 \\
\hline
\end{tabular}


Table 3: Trout densities between control sites, treatment sites, and all sites. Bolded and underlined values represent the greatest densities recorded for each species within treatment sites, control sites, or across all sites combined, respectively.

\begin{tabular}{|c|c|c|c|c|c|c|}
\hline & & Riffle & Low gradient & Int. gradient & Natural pool & Structure pool \\
\hline & & \multicolumn{5}{|c|}{ 2011: 1 year prior to restoration } \\
\hline \multirow{4}{*}{ Control } & Brook Trout & $\underline{0.0119}$ & 0.0012 & 0.0023 & 0.0090 & -- \\
\hline & Brown Trout & 0.0075 & 0.0046 & 0.0127 & $\underline{\mathbf{0 . 0 2 1 5}}$ & -- \\
\hline & Rainbow Trout & 0.0060 & 0.0035 & 0.0069 & 0.0124 & -- \\
\hline & Total & 0.0253 & 0.0093 & 0.0219 & $\underline{0.0430}$ & -- \\
\hline \multirow{4}{*}{ Treatment } & Brook Trout & 0.0118 & 0.0058 & $\underline{0.0132}$ & 0.0105 & -- \\
\hline & Brown Trout & 0.0026 & 0.0000 & $\overline{0.0023}$ & $\underline{0.0144}$ & -- \\
\hline & Rainbow Trout & $\underline{0.0118}$ & 0.0000 & 0.0016 & 0.0079 & -- \\
\hline & Total & $\overline{0.0262}$ & 0.0058 & 0.0171 & $\underline{0.0328}$ & -- \\
\hline \multirow{4}{*}{ Total } & Brook Trout & $\underline{0.0120}$ & 0.0029 & 0.0088 & 0.0085 & -- \\
\hline & Brown Trout & $\overline{0.0050}$ & 0.0029 & 0.0065 & $\underline{0.0160}$ & -- \\
\hline & Rainbow Trout & 0.0091 & 0.0022 & 0.0037 & $\underline{0.0096}$ & -- \\
\hline & Total & 0.0258 & 0.0080 & 0.0191 & $\overline{0.0341}$ & -- \\
\hline & & \multicolumn{5}{|c|}{ 2013: 1 year post restoration } \\
\hline \multirow{4}{*}{ Control } & Brook Trout & $\underline{\mathbf{0 . 0 3 3 9}}$ & 0.0066 & 0.0091 & 0.0106 & -- \\
\hline & Brown Trout & 0.0068 & 0.0028 & 0.0054 & $\underline{0.0176}$ & -- \\
\hline & Rainbow Trout & 0.0000 & 0.0019 & 0.0006 & $\underline{0.0035}$ & -- \\
\hline & Total & $\underline{0.0407}$ & 0.0113 & 0.0151 & $\overline{0.0317}$ & -- \\
\hline \multirow{4}{*}{ Treatment } & Brook Trout & $\overline{\mathbf{0 . 0 4 8 1}}$ & 0.0018 & 0.0045 & 0.0100 & 0.0176 \\
\hline & Brown Trout & $\overline{0.0000}$ & 0.0000 & 0.0023 & $\underline{0.0080}$ & 0.0000 \\
\hline & Rainbow Trout & 0.0000 & 0.0000 & 0.0005 & $\overline{0.0000}$ & $\underline{0.0044}$ \\
\hline & Total & $\underline{0.0481}$ & 0.0018 & 0.0073 & 0.0180 & $\overline{0.0220}$ \\
\hline \multirow{4}{*}{ Total } & Brook Trout & $\underline{0.0401}$ & 0.0049 & 0.0066 & 0.0102 & 0.0176 \\
\hline & Brown Trout & $\overline{0.0038}$ & 0.0019 & 0.0037 & $\underline{0.0115}$ & 0 \\
\hline & Rainbow Trout & 0.0000 & 0.0012 & 0.0005 & 0.0013 & $\underline{0.0044}$ \\
\hline & Total & $\underline{0.0440}$ & 0.0080 & 0.0106 & 0.0229 & $\overline{0.0220}$ \\
\hline & & \multicolumn{5}{|c|}{$2015: 3$ years post restoration } \\
\hline \multirow{4}{*}{ Control } & Brook Trout & $\underline{0.0146}$ & 0.0028 & 0.0101 & 0.0039 & -- \\
\hline & Brown Trout & 0.0000 & $\underline{0.0028}$ & 0.0020 & 0.0019 & -- \\
\hline & Rainbow Trout & 0.0049 & $\overline{0.0009}$ & 0.0007 & $\underline{0.0058}$ & -- \\
\hline & Total & 0.0195 & 0.0065 & 0.0128 & 0.0117 & -- \\
\hline \multirow{4}{*}{ Treatment } & Brook Trout & 0.0000 & 0.0069 & $\underline{0.0098}$ & 0.0070 & 0.0088 \\
\hline & Brown Trout & 0.0000 & 0.0042 & 0.0028 & $\underline{0.0070}$ & 0.0022 \\
\hline & Rainbow Trout & 0.0000 & 0.0000 & 0.0005 & $\overline{0.0023}$ & $\underline{0.0044}$ \\
\hline & Total & 0.0000 & 0.0111 & 0.0131 & 0.0164 & $\overline{0.0154}$ \\
\hline \multirow{4}{*}{ Total } & Brook Trout & 0.0082 & 0.0044 & $\underline{0.0102}$ & $0 . \overline{0053}$ & 0.0088 \\
\hline & Brown Trout & 0 & 0.0033 & 0.0026 & $\underline{0.0042}$ & 0.0022 \\
\hline & Rainbow Trout & 0.0027 & 0.0006 & 0.0006 & 0.0042 & $\underline{0.0044}$ \\
\hline & Total & 0.0110 & 0.0083 & 0.013 & 0.0138 & $\underline{0.0154}$ \\
\hline
\end{tabular}


Table 4: Densities (trout $/ \mathrm{m}$ ) for each trout over time for treatment sites, control sites, and all sites combined

\begin{tabular}{cccccc}
\hline & Year & Brook & Brown & Rainbow & Total \\
\hline \multirow{3}{*}{ Control } & 2011 & 0.0058 & 0.0119 & 0.0073 & 0.0250 \\
& 2013 & 0.0106 & 0.0058 & 0.0012 & 0.0176 \\
& 2015 & 0.0070 & 0.0021 & 0.0018 & 0.0109 \\
\multirow{3}{*}{ Treatment } & 2011 & 0.0111 & 0.0048 & 0.0051 & 0.0211 \\
& 2013 & 0.0089 & 0.0023 & 0.0008 & 0.0119 \\
& 2015 & 0.0084 & 0.0033 & 0.0010 & 0.0128 \\
\hline \multirow{3}{*}{ Total } & 2011 & 0.0085 & 0.0083 & 0.0062 & 0.0224 \\
& 2013 & 0.0097 & 0.0039 & 0.0010 & 0.0147 \\
& 2015 & 0.0084 & 0.0028 & 0.0016 & 0.0122 \\
\hline
\end{tabular}


Table 5: Zero-inflation regression model summary. Only models with a $\triangle \mathrm{AIC}$ value of less than 2are shown below.

\begin{tabular}{|c|c|c|c|c|}
\hline Species & & AICc & $\triangle \mathrm{AICc}$ & Weight \\
\hline \multicolumn{5}{|l|}{ Brook Trout } \\
\hline & $\mathrm{HCU}$ & 598.3 & 0.00 & 0.842 \\
\hline \multicolumn{5}{|l|}{ Brown Trout } \\
\hline & $\mathrm{HCU}+$ Year+Treatment+Treatment *Year & 402.1 & 0.00 & 0.588 \\
\hline & Year+HCU+Treatment & 403.0 & 0.90 & 0.376 \\
\hline \multicolumn{5}{|c|}{ Rainbow Trout } \\
\hline & Year+HCU+Treatment & 288.5 & 0.0 & 0.573 \\
\hline & Year+HCU & 290.0 & 1.50 & 0.270 \\
\hline \multicolumn{5}{|l|}{ All Trout } \\
\hline & Year+HCU+Treatment & 811.6 & 0.0 & 0.521 \\
\hline & Year+HCU & 812.8 & 1.24 & 0.280 \\
\hline
\end{tabular}


Table 6: Summary of results for the top-ranked models comparing trout density data to HCU usage, year, and treatment sites. INT represent intermediate gradient complexes, LOW represents low gradient complexes, and POOLS represents structure and natural pools. P values are shown. * indicates p-values between 0.5 and 0.01 , ** indicates values between 0.001 and 0.01 , and $* * *$ indicates p-values $<0.001$.

\begin{tabular}{|c|c|c|c|}
\hline $\begin{array}{l}\text { Species } \\
\quad \text { Parameters }\end{array}$ & Estimate & Standard Error & p-value \\
\hline \multicolumn{4}{|l|}{ Brook Trout } \\
\hline Intercept & -4.14 & 0.2195 & $<0.001^{* * *}$ \\
\hline INT & -0.56 & 0.2678 & $0.036^{*}$ \\
\hline LOW & -1.33 & 0.3445 & $<0.001^{* * *}$ \\
\hline POOLS & -0.5237 & 0.2936 & 0.0745 \\
\hline \multicolumn{4}{|l|}{ Brown Trout } \\
\hline Intercept & -5.39 & 0.4048 & $<0.001^{* * *}$ \\
\hline 2011 & 0.41 & 0.2950 & $0.0295^{*}$ \\
\hline 2015 & -0.96 & 0.4427 & 0.5363 \\
\hline INT & 0.24 & 0.3845 & 0.5419 \\
\hline LOW & -0.27 & 0.4453 & $0.0055^{* *}$ \\
\hline POOLS & 1.03 & 0.3710 & $0.0068 * *$ \\
\hline Treatment & -1.20 & 0.4442 & 0.5401 \\
\hline $2011 *$ Treatment & 0.3290 & 0.5371 & $0.0344 *$ \\
\hline $2015 *$ Treatment & 1.3739 & 0.6496 & 0.9599 \\
\hline \multicolumn{4}{|l|}{ Rainbow Trout } \\
\hline Intercept & -6.0010 & 0.5064 & $<0.001^{* * *}$ \\
\hline 2011 & 1.4298 & 0.4277 & $<0.001 * * *$ \\
\hline 2015 & 0.0292 & 0.5154 & 0.6849 \\
\hline INT & -0.9727 & 0.4337 & $0.0249 *$ \\
\hline LOW & -1.1525 & 0.5195 & 0.0265 \\
\hline POOLS & 0.2780 & 0.3666 & 0.0571 \\
\hline Treatment & -0.5492 & 0.2886 & 0.3983 \\
\hline \multicolumn{4}{|l|}{ All Trout } \\
\hline Intercept & -3.7567 & 0.2173 & $<0.001^{* * *}$ \\
\hline 2011 & 0.3552 & 0.1725 & $0.0395^{*}$ \\
\hline 2015 & -0.0905 & 0.1899 & 0.6336 \\
\hline INT & -0.4127 & 0.2111 & 0.0505 \\
\hline LOW & -1.0395 & 0.2563 & $<0.001^{* * *}$ \\
\hline POOLS & 0.0641 & 0.2100 & 0.7603 \\
\hline Treatment & -0.2651 & 0.1435 & 0.0647 \\
\hline
\end{tabular}


Table 7: Comparison of habitat variables for occupied and un-occupied hydraulic channel units. IGR represents intermediate gradient riffles, INT represent intermediate gradient complexes, LOW represents low gradient complexes, and NAT represents natural pools, and STR represents structure pools. P values are shown.

\begin{tabular}{lccc}
\hline HCU & Present & Absent & p-value \\
Variables & & & \\
\hline IGR & & & \\
Depth (cm) & $18.24(3.33)$ & $21.94(7.15)$ & 0.218 \\
Avg. Velocity (m/s) & $0.36(0.13)$ & $0.32(0.12)$ & 0.470 \\
Distance to cover (m) & $12.08(7.11)$ & $14.13(8.49)$ & 0.599 \\
INT & & & \\
Depth (cm) & $23.92(4.83)$ & $23.71(4.89)$ & 0.944 \\
Avg. Velocity (m/s) & $0.27(0.09)$ & $0.28(0.08)$ & 0.513 \\
Distance to cover (m) & $22.79(23.70)$ & $25.40(25.66)$ & 0.683 \\
LOW & & & \\
Depth (cm) & $28.5(7.48)$ & $27.93(8.20)$ & 0.811 \\
Avg. Velocity (m/s) & $0.15(0.06)$ & $0.16(0.07)$ & 0.968 \\
Distance to cover (m) & $22.06(22.63)$ & $27.60(27.76)$ & 0.513 \\
NAT & & & \\
Depth (cm) & $48.10(14.65)$ & $50.96(15.17)$ & 0.558 \\
Avg. Velocity (m/s) & $0.13(0.0)$ & $0.12(0.09)$ & 0.0790 \\
Distance to cover (m) & $6.11(4.15)$ & $8.17(8.04)$ & 0.322 \\
STR & & & \\
Depth (cm) & $50.05(29.06)$ & $56.69(38.64)$ & 0.745 \\
Avg. Velocity (m/s) & $0.11(0.04)$ & $0.12(0.04)$ & 0.426 \\
Distance to cover (m) & $7.45(4.85)$ & $19.04(25.70)$ & 0.346 \\
\hline
\end{tabular}


Table 8: Number of hydraulic channel units containing brook, brown, sympatric, and no trout, $2013 \& 2015$.

\begin{tabular}{ccccccc}
\hline & Trout & IGR & LOW & INTER & NAT & STR \\
\hline \multirow{3}{*}{2013} & Brook & 3 & 4 & 7 & 4 & 2 \\
& Brown & 1 & 2 & 4 & 6 & 0 \\
& Sympatric & 1 & 0 & 7 & 1 & 0 \\
& None & 7 & 12 & 14 & 11 & 5 \\
\hline \multirow{3}{*}{2015} & Brook & 2 & 4 & 14 & 2 & 1 \\
& Brown & 0 & 3 & 1 & 4 & 1 \\
& Sympatric & 0 & 2 & 6 & 1 & 0 \\
& None & 7 & 14 & 11 & 11 & 5 \\
\hline \multirow{5}{*}{$2013 \& 2015$} & Brook & 5 & 8 & 21 & 6 & 3 \\
& Brown & 1 & 5 & 5 & 10 & 1 \\
& Sympatric & 1 & 2 & 13 & 2 & 0 \\
& None & 14 & 26 & 25 & 22 & 10 \\
\hline
\end{tabular}


Table 9: General linear mixed model (GLMM) results for brook trout, rainbow trout, and all trout combined.

\begin{tabular}{|c|c|c|c|c|c|}
\hline Species & Fixed Effects & Random Effects & AICc & $\triangle \mathrm{AICc}$ & Weight \\
\hline \multicolumn{6}{|l|}{ Brook } \\
\hline & Depth+DFC & Treatment:Year & 372.7 & 0.000 & 0.659 \\
\hline & Depth+AVG +DFC & Treatment:Year & 374.8 & 2.06 & 0.236 \\
\hline & $\mathrm{DEP}+\mathrm{AVG}+\mathrm{DFC}+\mathrm{DEP} * \mathrm{DFC}$ & Treatment:Year & 376.6 & 3.88 & \\
\hline \multirow[t]{3}{*}{ Brown } & DFC & Treatment:Year & 213.9 & 0.00 & \\
\hline & $\mathrm{DEP}+\mathrm{DFC}$ & Treatment:Year & 216.0 & 2.09 & \\
\hline & $\mathrm{DEP}+\mathrm{AVG}+\mathrm{DFC}$ & Treatment:Year & 217.7 & 3.76 & \\
\hline \multirow[t]{5}{*}{ Rainbow } & DEP & Treatment:Year & 115.3 & 0.00 & \\
\hline & $D E P+A V G+D F C$ & Treatment:Year & 115.6 & 0.24 & \\
\hline & $\mathrm{DEP}+\mathrm{AVG}$ & Treatment:Year & 115.9 & 0.60 & \\
\hline & $\mathrm{DEP}+\mathrm{DFC}$ & Treatment:Year & 117.4 & 2.05 & \\
\hline & $\mathrm{DEP}+\mathrm{AVG}+\mathrm{DFC}+\mathrm{DEP}+\mathrm{DFC}$ & Treatment:Year & 117.7 & 2.40 & \\
\hline \multicolumn{6}{|l|}{ All Trout } \\
\hline & DEP+DFC & Treatment:Year & 467.1 & 0.00 & \\
\hline & $\mathrm{DEP}+\mathrm{DFC}+\mathrm{AVG}$ & Treatment:Year & 468.8 & 1.63 & \\
\hline & $\mathrm{DEP}+\mathrm{AVG}+\mathrm{DFC}+\mathrm{DEP} * \mathrm{DFC}$ & Treatment:Year & 469.3 & 2.16 & \\
\hline & DFC & Treatment:Year & 470.3 & 3.21 & 0.101 \\
\hline
\end{tabular}


Table 10: Summary of results for the top-ranked models comparing trout density to average habitat characteristics within channel units. $\mathrm{P}$ values are shown. * indicates p-values between 0.5 and 0.01 , ** indicates values between 0.001 and 0.01 , and $* * *$ indicates p-values $<0.001$.

\begin{tabular}{llll}
\hline Species & & & \\
\hline \multicolumn{1}{c}{ Parameters } & Estimate & Standard Error & p-value \\
\hline $\begin{array}{l}\text { Brook Trout } \\
\text { Intercept }\end{array}$ & -1.90 & 0.143 & $<0.001^{* * *}$ \\
Depth & -0.54 & 0.177 & $0.002^{* *}$ \\
Distance to Cover & -0.47 & 0.141 & $<0.001^{* * *}$ \\
& & & \\
\hline Rainbow & & & \\
Intercept & -4.06 & 0.991 & $<0.001^{* * *}$ \\
Distance to Cover & -0.59 & 0.451 & 0.19 \\
& & & $<0.001^{* * *}$ \\
\hline Brown & & & 0.038 \\
Intercept & -3.31 & 0.230 & \\
Distance to Cover & -0.53 & 0.253 & \\
& & & $<0.001^{* * *}$ \\
\hline All Trout & & & $0.027^{*}$ \\
Intercept & -1.63 & 0.139 & $0.001^{* *}$ \\
Depth & -0.27 & 0.123 & \\
Distance to Cover & -0.44 & 0.129 & \\
\hline
\end{tabular}




\title{
Chapter 3: Microhabitat use by brook, brown, and rainbow trout in a restored high- elevation Appalachian stream
}

\begin{abstract}
Brook trout populations throughout the Appalachians have declined substantially over the past century and currently exist as fragmented populations across much of their range. Consequently, numerous restoration efforts have aimed to restore stream reaches from which they have suffered significant declines in order to foster greater population growth. We used snorkeling surveys to assess and compare microhabitat preferences of brook (Salvelinus fontinalis), brown (Salmo trutta), and rainbow trout (Oncorhynchus mykiss) in constructed and natural pool habitats in a restored high-elevation, fourth-order stream in east-central West Virginia, USA. Principal components analysis showed minimal overlap in microhabitat use among brook, brown, and rainbow trout, with brook trout consistently occupying shallower habitats near higher velocities. Individuals of all three species were consistently found $<2 \mathrm{~m}$ from suitable cover. Habitat partitioning was more defined between brook trout and nonnative trout in created pool habitats but showed greater overlap in natural pools. Allopatric brook trout occupied higher velocity and shallower habitats than brook trout sympatric with rainbow and brown trout. Size exerted significant influence on habitat selection for both brook and brown trout, but not for rainbow trout. Larger brook trout occupied deeper and shallower habitats closer to cover than smaller brook trout. A similar trend was observed for brown trout, resulting in greater habitat overlap between larger brook trout and smaller brown trout. Brown and rainbow trout were the only species that occupied thermal refugia $\left(>2^{\circ} \mathrm{C}\right.$ cooler than ambient stream temperature), and brook trout were observed feeding at temperatures as high as $25^{\circ} \mathrm{C}$. These results suggest that
\end{abstract}


brook trout and nonnative trout display overlap in microhabitat preferences, which is more pronounced at the upper limits of brook trout size distribution and lower limits of brown trout size distribution, and nonnatives out-compete brook trout for limited thermal refugia. Benefits of habitat restoration to brook trout populations in large rivers may only be fully realized in the absence of non-native species. Therefore, future research in this and other large river systems should characterize brook trout response in the absence of (or following removal of) non-native species.

\section{Introduction}

Brook trout (Salvelinus fontinalis) have been widely extirpated from the main stems of large fluvial systems across much of their range primarily due to habitat loss via anthropogenic disturbance and stream warming (Petty et al. 2014; Aunins et al. 2015). Today, many brook trout populations exist as genetically isolated populations within small tributaries (Letcher et al 2007), and thus are more susceptible to localized extinction events (Dunham et al 1997; Yamamoto 2002; Lowe 2003). Consequently, brook trout have become the focus of numerous conservation practices and habitat restoration efforts across their native range (Flebbe 1999; Hartman and Sweka 2006; McClurg et al. 2007; Poplar-Jeffers 2009). Recent restoration efforts have aimed to restore both physical (e.g., the installation of woody debris and in-stream structures, and culvert removal) and chemical (e.g., adding limestone sand to remediate acidified streams) parameters in an attempt to maximize habitat suitability and stream connectivity. These measures intend to restore brook trout to waters from which they have been extirpated and aim to maximize population growth in streams where populations still persist (Cole et al. 2001; McClurg et al. 2007; Poplar-Jeffers 2009; Beechie et al. 2012). Further habitat loss is expected under numerous 
climate prediction models (Flebbe et al. 2006), heightening the necessity to restore habitats capable of supporting thriving brook trout populations.

Many native brook trout populations in the eastern United States have gradually been replaced with nonnative brown or rainbow trout over the past few decades, especially in larger riverine systems (Faush and White 1981; Larson et al. 1995; Waters 1999; McKenna et al. 2013; Wagner et al. 2013). The presence of either brown or rainbow trout in steam reaches is often associated with lower brook trout abundance (Moore et al. 1983; Waters 1983; Larson and Moore 1985; Larson et al. 1995; Ohlund et al. 2008; Wagner et al. 2013), suggesting that nonnative species have a competitive advantage under certain stream conditions. Understanding the multi-scale factors that lead to this competitive advantage is necessary to effectively tailor restoration projects to brook trout's specific habitat preferences, including prioritization of selected watersheds and reaches for restoration (Merovich et al. 2013) and design of appropriate physical habitat modifications within the stream channels (Lepori et al. 2005).

Several studies have related occupancy and abundance probabilities of several salmonids species to watershed-scale variables (Hudy et al. 2008; Stranko et al. 2008; Wagner et al. 2013). Today, rainbow trout and brown trout thrive in larger fluvial systems that once held high abundances of brook trout (Moore 1983; Waters 1999; Wagner et al. 2013). Both species have greater occupancy rates than brook trout in watersheds with abundant land disturbance practices (Waters 1983; Moore 1983), such as agriculture and impervious development (Stranko et al. 2008; Hudy et al. 2008; McKenna et al. 2013; Wagner et al. 2013). Prior studies have also noted that both brown and rainbow trout increase in occupancy probability as streams gain size and decrease in gradient and elevation (Larson and Moore 1985; Rahel and Hubert 1991; Bozek and Hubert 1992; Ohlund 2008), likely due to their superior competitive ability at warmer stream 
temperatures (Taniguichi et al. 1998). Rates of replacement have been markedly faster at the margins of current brook trout range (Flebbe et al. 1994). Repeated stockings of nonnative trout into brook trout reaches further accelerate brook trout population declines, suggesting a direct competitive superiority of these nonnative species (McKenna et al. 2013).

Mechanisms for displacement of brook trout within larger stream reaches are not yet fully understood. Numerous studies have found that brown and rainbow trout can outcompete brook trout for resources, such as feeding locations and spawning grounds (Fausch and White 1981; Blanchet et al. 2007). Zimmerman and Vondracek (2007) established that brook trout and brown trout occupy similar niches, yet brown trout display greater growth rates than brook trout in sympatric populations, indicating that they may be directly outcompeting brook trout for available food (DeWald and Wilzbach 1992) or preferred space (Fausch and White 1981). Brown trout exhibit dominance over and show high levels of aggression toward brook trout when they occupy streams sympatrically (DeWald and Wilzbach 1992). Both brown and rainbow trout typically exhibit greater growth rates than brook trout downstream from the headwaters and reach a larger size at maturity (Larson and Moore 1985; Waters 1999). Size is often more important than individual species identity in determining dominance status (Sabo and Pauley 1997); thus, nonnative trout may have more access to limited resources, such as resting habitat, prey, and thermal refugia (Fausch and White 1981; Petty et al. 2014). Prior studies have found that brook trout occupy more optimal feeding positions further from cover when rainbow trout are removed from stream reaches (Lohr and West 1992) and occupy deeper habitat closer to cover and remain closer to the substrate while feeding in the presence of brown trout (DeWald and Wilzbach 1992). Previous studies have also noted that brook trout occupy slower velocity habitat in higher elevation stream reaches than rainbow trout in both sympatric and allopatric 
populations (Cunjak and Green1983), while brown trout are more commonly found in wider, shallower, lower elevation and lower gradient stream sections than brook and rainbow trout (Weigel and Sorenson 2001).

These studies begin to give insight into microscale habitat use and partitioning between these species; however, there is a paucity of research focused on determining specific microhabitat preferences in the context of restoration. Therefore, it is of interest to define preferred habitats of these three salmonid species and to determine if their habitat preferences differ between restored and natural habitats. Further insight into micro-scale habitat use will help to ensure habitat restoration projects are appropriately focused on creating ample preferred habitat.

While the overall goal of many coldwater stream restoration projects in the Appalachian Mountains is to foster growth for native brook trout populations, these projects may confer benefits on non-target organisms, such as exotic or invasive species. While studies have attempted to elucidate the effects of non-native salmonids on brook trout populations in natural stream reaches (Larson and Moore 1985; Magoulick and Wilzbach 1998; Ohlund et al. 2008; Butryn et al. 2013), no prior study has quantified the use of microhabitat by nonnative trout species within brook trout restoration projects. If optimal restored habitat is being monopolized by nonnative trout, significant alterations to the site selection, design, and implementation of brook trout restoration programs would be needed. Research is needed to determine the extent to which brown, rainbow, and brook trout are using these newly created habitats and if significant competition for preferred habitat is evident between these three species.

Increased understanding of microhabitat use and potential competition between brook trout and nonnative salmonids is critical to the implementation of effective brook trout restoration and conservation plans. The overarching goal of this study was to facilitate 
management of native brook trout in the face of continued anthropogenic- and climate-induced habitat loss. Through direct observation via snorkeling surveys, the specific objectives of our study were to 1) quantify and characterize overlap in microhabitat use, including use of thermal refugia, between native and nonnative trout occupying natural and restored pool habitats, and 2) quantify size-specific differences in microhabitat use for all trout species and for sympatric and allopatric brook trout, and 3) characterize use of thermal refugia by each trout species.

\section{Methods}

Study Area

The upper Shavers Fork Watershed is a high elevation (originates at $1300 \mathrm{~m}$ ), $554 \mathrm{~km}^{2}$ watershed located primarily in the Monongahela National Forest in east-central West Virginia (Godfrey 2006; Huntsman and Petty 2014). The Shavers Fork flows north until its confluence with the Black Fork to form the Cheat River near Parsons, WV. Land cover is predominantly mixed deciduous-coniferous forest with abundant red spruce (Picea rubens). The watershed contains a variety of stream environments, ranging from small, high-gradient, cold headwater seeps $\left(1>\mathrm{km}^{2}\right)$ to productive, low-gradient, warm main stem reaches $\left(>100 \mathrm{~km}^{2}\right)$ (Petty et al. 2001; Petty et al. 2005; McClurg et al. 2007; Petty et al. 2012; Huntsman and Petty 2014). The main stem of Shavers Fork possesses a high biomass of aquatic invertebrates and a diverse fish assembly, including brook trout, brown trout, rainbow trout, rosyside dace (Clinostomus funduloides), blacknose dace (Rhinichthys obtusus), longnose dace (Rhinichthys cataractae), central stoneroller (Campostoma anomalum), fantail darter (Etheostoma flabellare), mottled sculpin (Cottus bairdii), northern hogsucker (Hypentelium nigricans), creek chub (Semotilus atromaculatus), and river chub (Nocomis micropogon). Brook trout are the dominant species 
within the numerous headwater tributaries (Petty et al. 2014). Shavers Fork once supported a thriving brook trout fishery, but degradation due to acid precipitation, sediment deposition, and channel and riparian modification from decades of timber harvest activity have hindered populations throughout the latter half of the twentieth century (Petty et al. 2005).

In 2012, habitat structures were installed along a four and a half mile section of the upper Shavers Fork. The project included the construction of single-wing deflectors, rock vanes, and woody habitat structures, such as root wads and bank sills, designed to narrow the channel, increase velocity, and create pools and riffle areas. The main goal of the Shavers Fork restoration plan was to restore foraging, reproductive, and refuge habitat for brook trout (EBTJV 2012).

\section{Data Collection}

We conducted habitat availability and use assessments during the summers of 2015 and 2016. Highly variable flows during the 2015 sampling season limited the number of possible sampling events and observations. Therefore, only data collected during the summer of 2016 were used in subsequent analyses. We sampled microhabitat availability and use by brook, brown, and rainbow trout via snorkeling surveys in 34 pools along six miles of the Shavers Fork main stem (Figure 1). A total of 18 natural pools, 10 pools created with stone j-hook structures, and 6 pools created with the installation of toe wood were sampled a minimum of three times between June 8th, 2016 and July $14^{\text {th }} 2016$ (Figure 1). Restoration at Shavers Fork aimed to improve habitat by predominantly improving availability of pool habitat and creating access to thermal refugia, thus we focused our efforts in these channel units. Snorkeling efforts were focused in pools All surveys were conducted during low flow conditions [25 and 55 cubic feet 
per second (cfs)] as measured by the USGS gauging station (station \#03067510) on Shavers Fork.

Observers entered from the down-stream end of the pool and waited for at least five minutes to ensure any disturbed fish resumed normal behavior. Observers then slowly moved toward the front of the pool, oscillating from one bank to another to ensuring all areas were visually inspected. Focal point habitat use was only recorded for trout that maintained a single position for $>10$ seconds. These focal point locations for each trout were marked with a numbered, weighted bobber that was adjusted to focal depth. Trout length was visually estimated for each observation. A PVC rod marked with centimeters was carried by the snorkeler to aid in the accuracy of estimated length (O’Neal 2007). Focal depth $(\mathrm{cm})$, total depth $(\mathrm{cm})$, focal velocity $(\mathrm{m} / \mathrm{s})$, bottom water velocity $(\mathrm{m} / \mathrm{s})$, fastest velocity within $60 \mathrm{~cm}$ of the focal point $(\mathrm{m} / \mathrm{s})$, substrate composition, focal temperature $\left({ }^{\circ} \mathrm{C}\right)$, distance to cover $(\mathrm{m})$, and ratio between the distance to the head of the pool and total pool length (occupancy ratio) were measured for each observation. Fish cover was defined as any object (e.g., boulders, root wads, woody debris, undercut banks) capable of concealing a 15-20 cm fish (Petty et al. 2001). Occupancy of thermal refugia (defined as $>2{ }^{\circ} \mathrm{C}$ colder than average ambient stream temperature) was also noted. Stream temperature was measured in 10 locations randomly distributed throughout the sampling reach to determine ambient stream temperature.

Habitat availability was collected for all pools containing trout. Initial habitat availability was collected for each pool immediately after completion of a snorkeling survey where trout were observed. Secondary availability sampling of each pool was only conducted if flows differed by more than $20 \mathrm{cfs}$ (station \#03067510) from the previous sampling effort. Pool length and average width were measured for each sampling pool to determine the total area snorkeled. 
Transects were established every $5 \mathrm{~m}$ along the length of the each pool, beginning at the downstream end. Habitat variables (depth, average velocity, bottom velocity, fastest velocity within $60 \mathrm{~cm}$, distance to fish cover and cover type, and substrate) were then measured at five evenly spaced intervals across each transect to have an unbiased representation of habitat availability.

\section{Statistical Analyses}

Mean and standard deviation were calculated for focal habitat parameters for all trout species across structure pools, natural pools, and both pool types combined. Principal components analysis (PCA) was used to summarize microhabitat use among trout species and available habitats (Merovich and Petty 2010). Specifically, we used PCA to compare focal microhabitat use (depth, fastest velocity, average velocity, the difference between focal and fastest velocity, and distance to fish cover) among brook, brown, and rainbow trout with habitat availability across all pool types. Variables were assessed for normality using histograms. Only principal components with eigenvalues greater than one were used in analyses. We used one-way ANOVAs to tests for differences in habitat use (i.e. PC scores) among species, regardless of pool type. We then compared PC scores among species separately for natural and created structure pools. Finally, we compared PC scores of brook trout occupying habitats sympatrically and allopatrically with non-native species. We did not analyze allopatric and sympatric brook trout habitat use by pool type because of the low number of observations across each pool type. Biplots were created showing mean PC scores and 95\% confidence intervals for each species and for availability. Finally, ANCOVA was used to test for potential effects of fish length on observed habitat use (i.e., PC scores) among species and among allopatric and sympatric brook 
trout populations. We progressively increased model complexity to test for the minimum adequate model. We tested for common (i.e. same intercept) effects, additive (i.e., different intercepts, same slope) effects and then finally interactive (i.e., different intercepts and slopes) effects. Models were compared to the next most complex model using F-ratio tests and the minimum adequate model was selected. Assessment for normality of estimated trout length data revealed no need for data transformation. Sympatric and allopatric brook and brown trout length were compared using a Welch's two-sample T-test. Focal temperatures were not included in the PC analyses because of high diel variations in ambient stream temperature. Analysis of variance comparing brook, brown, and rainbow trout across all pools was used to determine if focal temperature differed by species. All statistical analyses were performed in R 3.0.2 (R Core Team 2013).

\section{Results}

Mircohabitat use by brook, brown, and rainbow trout

A total of 54 trout observations were recorded during the sampling period, including 21 brook trout, 20 brown trout, and 13 rainbow trout. Thirty-three trout (11 brook trout, 10 brown, 12 rainbow) were observed in natural pools, while 21 trout (10 brook, 10 brown, and 1 rainbow) were observed in constructed pools.

Principal components analysis reduced data into two significant components (i.e., eigenvalues $>1$ ) that explained a total of $73.6 \%$ of the variation in the data (Table 2). Average velocity, fastest velocity, and the difference between average and fastest velocities all decrease in value with increasing PC1 scores. Focal depth declined with decreasing PC2 scores, while distance to cover increased with increasing PC2 scores (Figure 2). 
ANOVA results indicated significant differences among species and availability along PC1 $\left(\mathrm{F}_{3,600}=4.38, p=0.004\right)$ and PC2 $\left(\mathrm{F}_{3,600}=23.76, p<0.001\right)$ [Table1]. Tukey post hoc tests indicated that, on average, brook trout occupied habitat with significantly greater fastest velocities and average velocities and areas with higher differences between fastest and average velocity than both brown and rainbow trout and availability. Brook, brown, and rainbow trout all showed preference for deeper than average available habitat with greater amounts of cover.

In created structure pools, analysis of variance revealed significant differences among groupings along both axes $\left(\mathrm{F}_{7,596}=3.85, p<0.001\right.$ for $\mathrm{PC} 1$ and $\mathrm{F}_{7,596}=10.28, p<0.001$ for $\left.\mathrm{PC} 2\right)$. Tukey post hoc tests determined that brook trout occupied habitats there were associated with greater velocities and greater differences between average and fastest velocity than brown trout and available habitat (Figure 3). Brown trout did not differ significantly from available habitat along PC1, but did occupy habitat significantly deeper than average available habitats with greater amounts of cover (i.e., PC 2). Only one rainbow trout was observed in constructed pools, so no significant differences between its habitat selection and that of other salmonids and available habitat were observed. In natural pools, brown and rainbow trout occupied greater focal depths closer to cover when compared to average available habitat. Brook trout also occupied deeper habitat closer to cover, but this was not significant at the $\alpha=0.05$ level. Both brown and rainbow trout did not differ significantly from brook trout along either PC1 or PC2 (Figure 4). No species differed significantly from average available habitat along PC1.

Habitat use by brook trout in pools where they existed sympatrically with nonnative trout differed significantly from allopatric brook trout habitat use (Figure 5). When present in pools with brown trout, brook trout occupied stream reaches with slower velocities, as indicated by significantly greater PC1 scores $\left(\mathrm{F}_{1,19}=40.84, p<0.001\right.$, ANOVA). Brook trout in allopatric and 
sympatric populations did not differ across PC2 scores, indicating that they did not select habitats with significantly different depths or velocities $\left(\mathrm{F}_{1,19}=0.094, p=0.76\right.$, ANOVA).

\section{Relationships between length and habitat selection}

Brown trout had a greater average estimated mean length $(349 \mathrm{~mm})$ than brook trout (179 $\mathrm{mm})$, but did not differ statistically from rainbow trout $(335 \mathrm{~mm})\left[F_{2,51}=22.162, p<0.001\right.$ ANOVA, Figure 6]. Similar length distribution were observed in both natural [brown (305), rainbow (337), brook(197)] and constructed (393, 300, 160, respectively) pools.

Across all pools, analysis of covariance (ANCOVA) [Table 3] indicated that that length was the only variable explaining significant variation in microhabitat use as defined by $\mathrm{PC} 1\left(R^{2}\right.$ $=0.34, F_{1,50}=25.39, p<0.001$, Figure 7) and PC2 scores $\left(R^{2}=0.46, F_{1,50}=38.47, p<0.001\right.$, Figure 8) across all pools. We found no statistical evidence of an interactive effect between species identity and length on PC scores. A similar result was observed on both PC1 $\left(R^{2}=0.36, F_{1}\right.$, ${ }_{29}=15.60, p<0.001$, Figure 9) and PC2 $\left(R^{2}=0.39, F_{1,29}=16.07, p<0.001\right.$, Figure 10) scores in natural pools and on PC2 $\left(R^{2}=0.53, F_{1,17}=19.02, p<0.001\right)$ scores in structure pools [Figure 12]. In contrast, species was the only variable that explained significant variation in microhabitat use as defined by PC1 in structure pools, demonstrating that species identity has the greatest influence on micro-selection of velocity regimes within this pool type $\left(R^{2}=0.35, F_{1,18}=36.12\right.$, $p<0.001$, Figure 11).

Similarly, sympatry was determined to have the greatest influence on PC1 scores, where sympatric brook trout had significantly higher PC1 scores $\left(R^{2}=0.68, F_{1,19}=40.84, p<0.001\right.$, Figure 13) than allopatric brook trout. Sympatric brook trout occupied significantly slower velocity habitats with less variability between average and fastest velocities, such as those found 
within the deeper sections of the snorkeled pools, than allopatric brook trout. For PC2 scores, length again was a significant predictor $\left(R^{2}=0.44, F_{1,18}=4.85, p=0.04\right.$, Figure 14), and intercepts do not significantly vary among species, indicating that length influences depth and fish cover habitat selection. Brook trout that inhabited pools with brown trout were larger (mean=204.0 $\mathrm{mm}$ ) than brook trout inhabiting pools allopatrically (mean=156.8 $\mathrm{mm}$ ), but this difference was not significant at the $\alpha=0.05$ level $\left(t_{14.03}=-2.01, p=0.06\right.$, Figure 15$)$. Interestingly, brown trout in pools occupied by brook trout were smaller $($ mean $=318.8 \mathrm{~mm})$ than brown trout that occupied pools alone (mean=369.2), but again this difference was not significant $\left(t_{15.81}=0.85, p=0.41\right.$, Figure 16).

\section{Temperature and habitat use}

The highest ambient stream temperatures recorded during the sampling period was $27.0^{\circ} \mathrm{C}$ in pools downstream of long and shallow glide complexes during July surveys. Overall, brook trout occupied habitat with an average temperature of $19.7^{\circ} \mathrm{C}(\mathrm{sd}=1.98)$, while brown trout and rainbow trout occupied habitat with an average stream temperature of $19.9(\mathrm{sd}=1.99)$ and 20.2 ( $\mathrm{sd}=1.76)$, respectively. However, there were no significant differences in focal temperatures between the three species $\left(F_{2,51}=0.258 p=0.774\right.$ ANOVA $)$. Two brook trout were observed occupying focal points with temperatures that exceeded $22.0^{\circ} \mathrm{C}$, and the highest observed focal temperature of a feeding brook trout was $25.0^{\circ} \mathrm{C}$. Brown trout were observed occupying temperatures as high as $23.9^{\circ} \mathrm{C}$, while the highest temperature observed for a rainbow trout was $23.0^{\circ} \mathrm{C}$. No brook trout were observed occupying obvious thermal refugia (temperature $>2{ }^{\circ} \mathrm{C}$ cooler than ambient stream temperature), but three brown trout and one rainbow trout were 
observed utilizing these cooler areas. These refugia resulted from both in-stream spring upwellings and cold water input from tributaries.

\section{Discussion}

Our results indicate that brook trout microhabitat use differs from nonnative salmonid species and is largely influenced by size and sympatry. On average, brook trout use shallower habitat further from cover and occupy areas with higher and more variable velocities than both brown and rainbow trout. Size significantly influences microhabitat preference for both brook and brown trout, where larger individuals preferred deeper and slower habitats than smaller trout. Larger brook trout were also more likely to occupy pools sympatrically with nonnative trout.

Numerous studies note that brook trout are the dominant salmonid species in higher elevation and higher gradient stream reaches in watersheds containing exotic brown and rainbow trout, suggesting that they have a competitive advantage in shallower streams with higher velocities (Larson and Moore 1985; Bozek et al. 1992; Weigel and Sorenson 2001). During this

study, many brook trout were observed occupying hydraulically-sheltered, low-velocity positions in close proximity to faster moving water, thus maximizing feeding opportunities on drifting invertebrates while minimizing energy expenditure (Fauch and White 1981; Cunjak and Power 1986; Facey and Grossman 1990; Gustafson et al. 2013). Specifically within structure pools, brook trout were often observed maintaining positions within the small, hydraulically sheltered pockets created by the large stones used for the construction of j-hooks, occasionally moving into the higher flows to snatch a drifting macroinvertebrate. While the primary purpose of these structures is to create deep scour pools by concentrating flows into the center of the stream channel, the hydraulic complexity created by the large boulders at the head of these pools 
appears to create a new niche that is suitable for brook trout, but may be unsuitable for most brown or rainbow trout due to their larger size. Rosenfeld and Boss (2001) note a similar pattern in cutthroat trout, where smaller salmonids were able to occupy complex riffle habitats due to their size and lower energetic needs. Deeper pools in Shavers Fork offered a greater amount of cover and contained a diverse array of smaller fish species, providing larger trout with ample concealed areas and offering greater opportunities for piscivory. Riffle areas have greater benthic macroinvertebrate drift rates (LaPerriere 1981), making them ideal for smaller, invertivore brook trout. Additionally, the warmer ambient water temperatures seen in Shavers main stem likely forces larger trout to adopt piscivorous behavior to allow them to meet their energy need; however, smaller brook trout do not incur as great of an energy demand, and thus can acquire adequate nutrients from invertivory (Rosenfeld and Boss 2001; Petty et al 2014).

Significant differences in habitat use between brook trout inhabiting pools allopatrically and sympatrically with brown or rainbow trout suggest that the presence of nonnative trout species impacts microhabitat selection. It was expected that brook trout would occupy deeper stream reaches closer to cover in the absence of brown trout; however, the opposite pattern was observed. Allopatric brook trout occupied shallower and faster habitats than brook trout occupying pools sympatrically with brown or rainbow trout. Allopatric brook trout also occupied locations further away from cover, but this difference was not significant. These findings are consistent with the findings of DeWald and Wilzbach (1992), where brook trout occupied deeper pools closer to cover and fed closer to the substrate when brown trout were present. Brook trout in pools where larger brown or rainbow trout are present may be exposed to greater risks of predation, and thus remain in deeper pool areas closer to cover. Brook trout in sympatric pools were often larger than brook trout occupying allopatric pools, further indicating that smaller 
brook trout may be at risk for predation or are simply out-competed for resources and optimal habitat, and thus avoid pools with brown trout. Garman and Niehson (1982) documented that large brown trout (>280mm) heavily fed on native fish assemblages, reducing abundances of native species and increasing the average size of prey species within the study reaches. Large brown trout may be having a similar influence on the number and size of brook trout inhabiting the main stem of Shavers Fork and may be influencing the pool selection of smaller brook trout. Occupation of deeper habitats closer to cover may indicate that larger brook trout are able to compete with nonnative trout for preferred habitat, but smaller brook trout are relegated to shallower, hydraulically sheltered areas that larger brown trout cannot efficiently occupy. Habitat complexity was a critical factor influencing the presence or absence of trout from specific pools. Numerous structure pools without wood enhancements lacked cover and reasonable structure within the deepest sections of the pool, and few trout were observed occupying these areas. When trout were present within these structure pools, they often occupied habitat at the front of the pools, close to the cover created by the large boulders used to construct the cross vanes. Trout were present in the greatest numbers in small pools that contained large amounts of woody debris, which aligns with results from prior studies (Young 1996; Flebbe 1999; Neumann and Wildman 2002). Up to eight trout, including individuals from all three study species, were observed sharing a single pool that contained a large freshly fallen red spruce tree (Picea rubens). Woody debris inputs greatly increases microhabitat availability, providing ample fish cover and substrate to harbor benthic macroinvertebrates. These observations indicated that increasing habitat complexity and including woody components in salmonid habitat restoration may be critical to ensuring that restoration is appropriately tailored to the target species (Lepori et al. 2005). However, previous studies have noted that wood habitat features must be 
implemented over broad spatial scales to substantially influence total population densities within a system (Hartman and Sweka 2006).

Only brown trout and rainbow trout were found in microhabitats deemed thermal refugia $\left(>2{ }^{\circ} \mathrm{C}\right.$ colder than ambient stream temperature). The larger size of both rainbow and brown trout (Larson and Moore 1985; DeWald and Wilzbach 1992; Waters 1999) may confer competitive advantages upon these species over brook trout, allowing them to outcompete brook trout for colder refugia. In addition to occupying the only observed thermal refugia, nonnative trout were also observed forcing brook trout from optimal resting locations. At one site, a larger brown trout was observed forcing a brook trout from its occupied space, leaving it to occupy a position lacking suitable cover further from faster velocity water that is optimal for foraging. In another pool, a disturbed brown trout forced a brook trout from its occupancy under the cover of a boulder within the deepest portion of the pool. Fausch and White (1981) observed similar interactions between brook and brown trout and noted this dominance for preferred resting positions as a potential factor in the replacement of brook trout by brown trout in northeastern streams. Thermal refugia are likely a critically limiting habitat feature in the main stem of Shavers Fork during the summer as temperatures climb above brook trout's critical limits (Petty et al. 2012; Petty et al. 2014). Dominance of thermal refugia by nonnative trout, especially in warmer years, may hinder brook trout from utilizing the highly productive main stem of Shavers Fork (Petty et al. 2014). Brook trout were not observed in the main stem of Shavers Fork during July, when ambient stream temperatures regularly climbed above $24^{\circ} \mathrm{C}$ during the day, but likely moved into cold water tributaries. Both brown and rainbow trout remained present in the main stem throughout this period. 
Ambient stream temperatures at Shavers Fork often exceeds limits for optimal growth and survival of brook trout (Taniguichi et al. 1998; Hartman and Sweka 2001). Although brook trout were not observed during the peak of the summer, brook trout were observed occupying temperatures that exceed the previously documented thresholds. One brook trout was observed feeding at the front of a structure pool while occupying a position where water temperature was measured at $25.0^{\circ} \mathrm{C}$. No notable thermal refugia were present near this feeding position. Tanaguichi et al. (1998) found that brook trout feeding behavior ceased at $24^{\circ} \mathrm{C}$ in lab environments. At that threshold, both creek chub and brown trout became competitively dominant over brook trout across all velocity ranges in laboratory streams. Hartman and Sweka (2001) found that brook trout consumption rates increased rapidly from 8 to $21^{\circ} \mathrm{C}$, but steeply declined at higher temperatures, substantially diminishing growth rates. While it is unexpected that brook trout would occupy temperatures at the upper limits of their thermal tolerance range, increased thermal tolerance has been observed in brook trout when they were gradually exposed to warmer water temperatures (Lee and Rinne 1980). It is possible that thermal tolerance progressively increased as stream temperatures steadily raised throughout the summer. It is also highly probable that thermal tolerance has a genetic component. Greater thermal tolerance would be unquestionably beneficial because it would confer greater fitness to individuals due to increased ability to utilize productive main stem habitat (Petty et al. 2014). Specific thermal tolerance genes have been located within rainbow trout, and evidence suggests that selective breeding can increase growth potential at higher temperatures (Perry et al. 2005). While temperature sensitivity is likely mediated by a complex array of genes, continued benefits of access to warmer water may lead to continually amplified thermal tolerance over many 
generations. Further study is needed to determine brook trout genetic adaptability and phenotypic plasticity in response to temperature.

\section{Conclusions}

Data collected during this study show that microhabitat selection differs across species, with brook trout preferring shallower habitat near areas with faster water velocity, and brown and rainbow trout preferring deeper areas within pools close to cover. However, size appears to contribute more to habitat selection than species identity, with large brook trout and small brown trout occupying similar habitats. Differences in brook trout habitat selection between pools with and without nonnative trout suggest brook trout modify their behavior and habitat selection in the presence of brown and rainbow trout. Removal of nonnative trout from upper Shavers Fork and subsequent snorkeling surveys and population monitoring could determine their influence on both habitat use and long-term brook trout population trends. Sampling over successive summers may be required to negate the influence changes in mean summer water temperature, turbidity, and flow. 


\section{Literature Cited}

Al-Chokhachy, R., Schmetterling, D.A., Clancy, C., Saffel, P., Kovach, R.P., Nyce, L.G., Liermann, B., Fredenberg, W.A. and Pierce, R. 2016. Are brown trout replacing or displacing bull trout populations in a changing climate? Canadian Journal of Fisheries and Aquatic Sciences 10.1139/cjfas-2015-0293

Beechie, T., H. Imaki, J. Green, A. Wade, H. Wu, G. Pess, P. Roni, J. Kimball, J. Stanford, P. Kiffney, and N. Mantua. 2012. Restoring salmon habitat for a changing climate. River Research and Applications 28:939-960.

Blanchet, S., G. Loot, G. Grenouillet, and S. Brosse. 2007. Competitive interactions between native and exotic salmonids: a combined field and laboratory demonstration. Ecology of Freshwater Fishes 16:133-143.

Buisson, L. and G. Grenouillet. 2009. Contrasted impacts of climate change on stream fish assemblages along an environmental gradient. Diversity and Distributions, 15:613-626.

Butryn, R.S. D.L Parrish, and D.M. Rizzo. 2013. Summer stream temperatures metrics for predicting brook trout (Salvelinus fontinalis) distribution in streams. Hydrobiologia 703:47-57.

Clark, M.E. and K.A. Rose. 1997a. Factors affecting competitive dominance of rainbow trout over brook trout in southern Appalachian streams: implications of an individual-based model. Transactions of the American Fisheries Society 126:1-20.

Clark, M.E. and K.A. Rose. 1997b. Individual-based model of stream-resident rainbow trout and brook char: model description, corroboration, and effects of sympatry and spawning season duration. Ecological Modeling 94:157-175. 
Cole, M.B., D.E. Arnole, B.J. Watten, and W.F. Krise. 2001. Haematological and physiological responses of brook charr, to untreated and limestone-neutralized acid mine drainage. Journal of fish biology, 59:79-91.

Cunjack; R.A. and J.M. Green. 1982. Habitat utilization by brook char (Salvelinus fontinalis) and rainbow trout (Salmo gairdneri) in Newfoundland streams. Canadian Journal of Zoology 61:1214-1219.

Cunjak, R.A. and G. Power. 1986. Winter habitat utilization by stream resident brook trout (Salvelinus fontinalis) and brown trout (Salmo trutta). Canadian Journal of Aquatic Sciences 43:1970-1981.

DeWald, L., and M.A. Wilzbach. 1992. Interactions between native brook trout and hatchery brown trout on habitat use, feeding, and growth. Transactions of the American Fisheries Society 121:287-296.

Dolloff, A., J. Kershner, and R. Thurow. 1996. Underwater Observation. in B.R. Murphy and D.W. Willis, editors. Fisheries Techniques, second edition. American Fisheries Society, Bethesda, Maryland.

Dunham, J.B., Vinyard, G.L., and B.E. Rieman. 1997. Habitat fragmentation and extinction risk of Lahontan cutthroat trout. North American Journal of Fisheries Management. 17:11261133.

Eastern Brook Trout Joint Venture Project Completion Form. 2012. EBTJV.

Facey, D.E. and G.D. Grossman. 1990. The metabolic cost of maintaining position for four North American stream fishes: effects of season and velocity. Physiological Zoology 63:757-776. 
Fausch, K.D. an R.J. White. 1981. Competition between brook trout Salvelinus fontinalis) and Brown Trout (Salmo trutta) for Positions in a Michigan Stream. Canadian Journal of Fisheries and Aquatic Sciences. 38:1220-1227.

Fausch, K.D. and R.J. White. 1986. Competition among juveniles of coho salmon, brook trout, and brown trout in a laboratory stream and implications for Great Lakes Tributaries. Transactions of the American Fisheries Society 115:363-381.

Flebbe, P.A. 1994. A regional view of the margin: Salmonid abundance and distribution in the Southern Appalachian Mountains of North Carolina and Virginia. Transactions of the American Fisheries Society 123:657-667.

Flebbe, P.A. 1999 Trout use of woody debris and habitat in Wine Spring, North Carolina. Forest Ecology and Management 114:367-376.

Flebbe, P.A., L.D. Roghair, J.L. Bruggink. 2006. Spatial modeling to project southern Appalachian trout distribution in a warmer climate. Transactions of the American Fisheries Society 135:1371-1382.

Goldstein, R. M. 1978. Quantitative comparison of seining and underwater observation for stream fishery surveys. Progressive Fish-Culturist 40:108-111.

Griffith, J.S. 1974. Utilization of invertebrate drift by brook trout (Salvelinus fontinalis) and cutthroat trout (Salmo clarki) in small streams in Idaho. Transactions of the American Fisheries Society 103:440-447.

Gustafsson, S., M. Österling, J. Skurdal, L.D. Schneider, and O. Calles. 2013. Macroinvertebrate colonization of a nature-like fishway: the effects of adding habitat heterogeneity. Ecological Engineering 61:345-353. 
Hartman, K.J. and J.A. Sweka. 2001. Development of a bioenergetics model for Appalachian brook trout. Proceedings of the Annual conference of Southeast Association of Fish and Wildlife Agencies 55:38-51.

Hartman, K.J. and J.A. Sweka. 2006. Effect of large woody debris addition on stream habitat and brook trout populations in Appalachian streams. Hydrobiologia 559:363-378.

Harmon, M.E., J. F. Franklin, F.J. Swanson, P. Sollins, S. V. Gregory, J. D. Lattin, N. H. Anderson et al. 1986. Ecology of coarse woody debris in temperate ecosystems. Advances in Ecological Research 15:133-302.

Huntsman, B.M. and J.T. Petty. 2014. Density-dependent regulation of brook trout population dynamics along a core-periphery distribution gradient in a central Appalachian watershed. PLOS One 9:e91763.

Heggenes, J.H., A. Brabrand, and S.J. Saltveit. 1990. Comparison of three methods for studies of stream habitat use by young brown trout and Atlantic salmon. Transactions of the American Fisheries Society 119:101-111.

Jonsson, N. T., E. Naesje, B. Jonsson, Saksgard, and O.T. Sandlund. 1999. The influence of piscivory on life history traits of brown trout. Journal of fish Biology 55:1129-1141.

LaPerriere, J. D. 1981. Chemical and physical influences on invertebrate drift in subarctic Alaskan streams. Master's Thesis. Iowa State University, Ames, Iowa, USA.

Larson, G.L., S.E. Moore, and B. Carter. 1995. Ebb and flow of encroachment by nonnative rainbow trout in a small stream in the southern Appalachian mountains. Transactions of the American Fisheries Society 124:613-622. 
Larson. G.L and S.E. Moore. 1985. Encroachment of exotic rainbow trout into stream populations of native brook trout in the southern Appalachian Mountains. Transactions of the American Fisheries Society 114:195-203.

Lepori, F., D. Palm, E. Branannas, and B. Malmqvist. 2005. Does restoration of structural heterogeneity in stream enhance fish and macroinvertebrate density? Ecological Applications 15:2060-2071.

Lohr, S.C. and J.L. West. 1992. Microhabitat selection by brook and rainbow trout in a southern Appalachian stream. Transactions of the American Fisheries Society 121:729-736.

Lowe, W.H. 2003. Linking dispersal to local population dynamics: a case-study using a headwater salamander system. Ecology 84:2145-2154.

Hudy, M., T.M. Thieling, N. Gillespie, and E.P. Smith. 2008. Distribution, status and land use characteristics of subwatersheds within the native range of brook trout in the eastern native range of brook trout in the Eastern United States. North American Journal of Fisheries Management 28:1069-1085.

Magoulick, D.D. and M.A. Wilzbach. 1998. Effect of temperature and macrohabitat on interspecific aggression, foraging success, and growth of brook trout and rainbow trout pairs in laboratory systems. Transactions of the American Fisheries Society 127:708-717.

Marchetti, M.P. and P.B. Moyle. 2001. Effects of flow regime on fish assemblages in a regulated California stream. Ecological Applications, 11:530-539.

McClurg, S.E., J.T. Petty, P.M. Mazik, and J.L. Clayton. 2007. Stream ecosystem response to limestone treatment in acid impacted watersheds of the Allegheny Plateau. Ecological Applications 17:1087-1104. 
McKenna, J.E., M.T. Slattery, and K.M. Clifford. 2013. Broad-scale patterns of brook trout responses to introduced brown trout in New York. North American Journal of Fisheries Management 33:1221-1235.

Merovich, G.T. and J.T. Petty. 2010. Continuous response of benthic macroinvertebrate assemblages to a discrete disturbance gradient: consequences for diagnosing stressors. Journal of the North American Benthological Society. 29:1241-1257.

Merovich, G.T., J.T. Petty, M.P. Strager and J.B. Fulton. 2013. Hierarchical classification of stream condition: a house-neighborhood framework for establishing priorities in complex riverscapes. Freshwater Science 32:874-891.

Moore, S.E., B. Ridley, and G.L. Larson. 1983. Standing crops of brook trout concurrent with removal of rainbow trout from selected streams in Great Smokey Mountain National Park. North American Journal of Fisheries Management 3:72-80.

Mullner, S.A., T.A. Wesche and W.A. Hubert. 1998. Snorkeling as an alternative to depletion electrofishing for estimating abundance and length-class frequencies of trout in small streams. North American Journal of Fisheries Management 18:947-953.

Nakano, S. 1995. Differences in resource use, growth, and emigration under the influences of a dominance hierarchy in fluvial red-spotted masu salmon in a natural habitat. Journal of America Ecology 64:75-84.

Neumann, R. M. \& T. L. Wildman, 2002. Relationships between trout habitat use and woody debris in two southern New England streams. Ecology of Freshwater Fish 11: 240-250.

Ohlund, G., F Nordwall, E. Degerman, T. Eriksson. 2008. Life history and large-scale habitat use of brown trout (Salmo trutta) and brook trout (Salvelinus fontanalis)- implications for species replacement patterns. Canadian Journal of Aquatic Science 65:633-644. 
O’Neal, J.S. 2007. Snorkel surveys. In: Johnson D.H., B.M. Shrier, J.S. O’Neal, J.A. Knutzen, X. Augerot, T.A. O’Neil, and T.N. Pearsons (eds) Salmonid field protocols handbook: Techniques for assessing status and trends in salmon and trout populations. American Fisheries Society, Bethesda. 325-340.

Perry, G.M.L., C.M. Martyniuk, M.M. Ferguson, and R.G. Danzmann. 2005. Genetic parameter for upper thermal tolerance and growth-related traits in rainbow trout (Oncorhynchus mykiss). Aquaculture 250:120-128.

Petty, J. T. and E.P. Merriam. 2012. Brook Trout Restoration. Nature Education Knowledge 3:17.

Petty, J.T., J.L. Hansbarger, B.L. Huntsman, and P.M. Mazik. 2012. Brook trout movement in response to temperature, flow, and thermal refugia within a complex Appalachian riverscape. Transactions of the American Fisheries Society 141:1060-1073.

Petty, J.T., D. Thorne, B.L. Huntsman, and P.M. Mazik. 2014. The temperature productivity squeeze: constraints on brook trout growth along an Appalachian River continuum. Hydrobiologia 727:151-166.

Sabo, J.L. and G.B. Pauley. 1997. Competition between stream-dwelling cutthroat trout (Oncorhynchus clarki) and coho salmon (Oncorhynchus kisutch): effects of relative size and population origin. Canadian Journal of Fisheries and Aquatic Sciences:54:26092617.

Schlosser, I.J., 1982. Fish community structure and function along two habitat gradients in a headwater stream. Ecological monographs 52:395-414.

Sponseller, R.A., E.F. Benfield, H.M. Valett. 2001. Relationship between land use, spatial scale, and stream macroinvertebrate communities. Freshwater Biology 46:1409-1424. 
Stranko, S.A., R.H. Hilderbrand, R.P. Morgan, M.W. Staley, A.J. Becker, A. RosenberryLincoln, E.S. Perry, and P.T. Jacobson. 2008. Brook trout temperature declines with land cover and temperature changes in Maryland. North American Journal of Fisheries Management 28:1223-1232.

Taniguchi, Y., D. C. Novinger, F. J. Rahel, and K. Gerow. 1998. Temperature mediation of competitive interactions among three fish species, brook trout, brown trout, and creek chub, that replace each other along longitudinal stream gradients. Canadian Journal of Fisheries and Aquatic Sciences 55:1894-1901.

Vannote, R.L., G.W. Minshall, K.W. Cummins, K.W., J.R. Sedell, and C.E. Cushing. 1980. The river continuum concept. Canadian Journal of Fisheries and Aquatic Sciences. 37: 130137.

Wagner, T., J.T. Deweber, J. Detar, and J.A. Sweka. 2013. Landscape-scale evaluation of asymmetric interactions between brown trout and brook trout using two-species occupancy models. Transactions of the American Fisheries Society 142:353-361.

Waters, T.F. 1983. Replacement of brook trout by brown trout over 15 years in a Minnesota stream: production and abundance. Transactions of the American Fisheries Society 112:137-146.

Waters, T.F. 1999. Long-term production dynamics in Valley Creek, Minnesota. Transactions of the American Fisheries Society 128:1151-1162.

Yamamoto, M.K. 2002. Effects of habitat fragmentation by damming on the persistence of stream-dwelling charr populations. Conservation Biology 16:1318-1323. 
Young, M., 1996. Summer movements and habitat use by Colorado River cutthroat trout (Oncohynchus clarki pleuriticus) in small, montane streams. Canadian Journal of Fisheries and Aquatic Sciences 53: 1403-1408. 
Tables and Figures

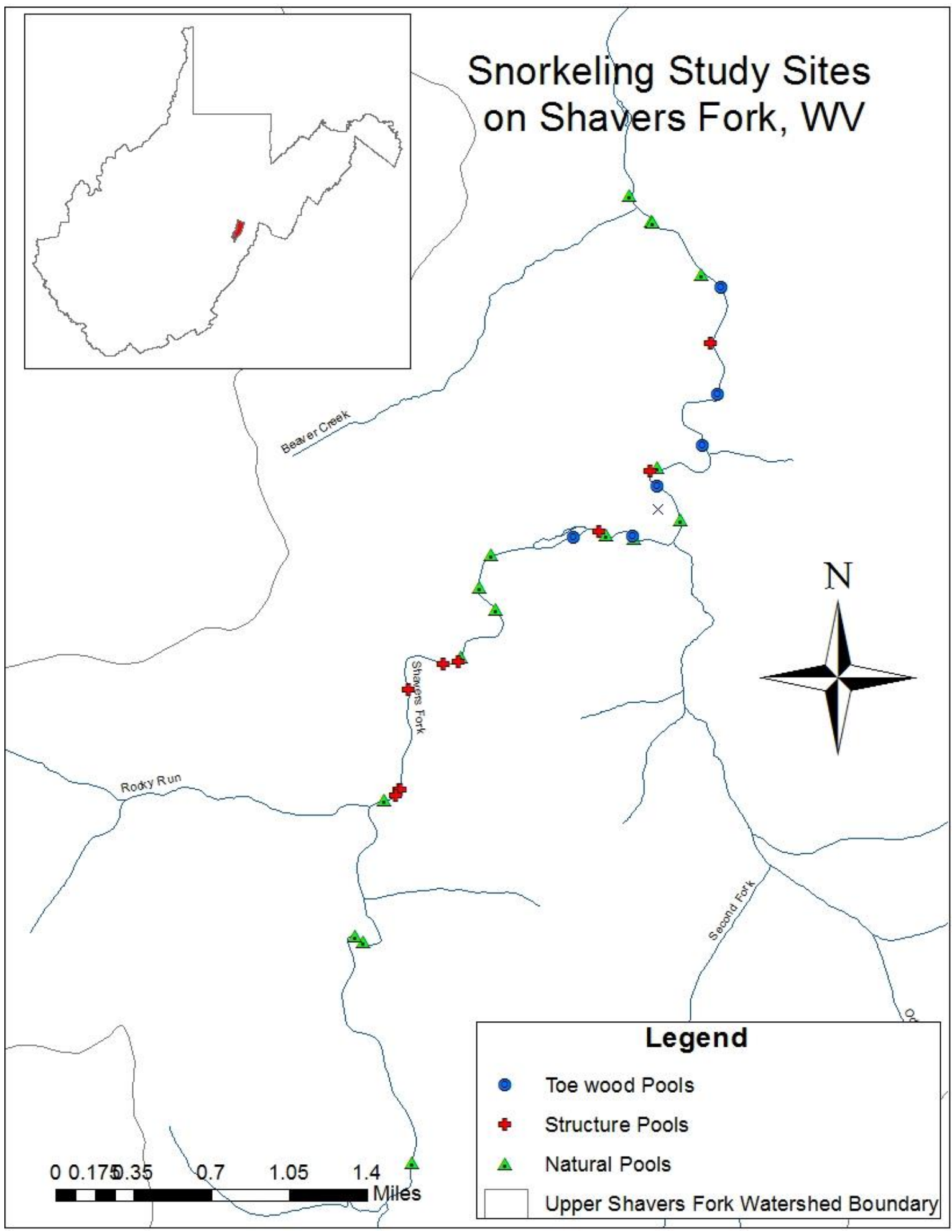

Figure 2: Map of the upper Shavers Fork study area. Natural pools, rock vane structure pools, and toe wood pools are noted. 
Table 1: Mean (and standard deviation) of habitat data and PC scores in all pools combined, in structure pools, and in natural pools.

\begin{tabular}{|c|c|c|c|c|c|}
\hline & & Brook & Brown & Rainbow & Available \\
\hline \multirow{9}{*}{$\begin{array}{l}\frac{n}{0} \\
8 \\
0 \\
\frac{1}{4}\end{array}$} & Depth (cm) & $47.4(24.3)$ & $88.7(34.9)$ & $71.1(13.0)$ & $48.6(34.2)$ \\
\hline & Average velocity $(\mathrm{m} / \mathrm{s})$ & $0.13(0.11)$ & $0.07(0.07$ & $0.10(0.08)$ & $0.11(0.13)$ \\
\hline & Fastest Velocity (m/s) & $0.38(0.30)$ & $0.16(0.24)$ & $0.15(0.11)$ & $0.19(0.25)$ \\
\hline & $\Delta$ Velocity & $0.24(0.27)$ & $0.09(0.23)$ & $0.05(0.05)$ & $0.08(0.18)$ \\
\hline & Distance to Cover (m) & $1.31(1.44)$ & $0.5(0.99)$ & $0.38(0.77)$ & $5.39(4.12)$ \\
\hline & Occupancy Ratio & $0.32(0.19)$ & $0.40(0.24)$ & $0.44(0.14)$ & --- \\
\hline & Temperature $\left({ }^{\circ} \mathrm{C}\right)$ & $19.70(1.98)$ & $19.86(1.99)$ & $20.19(1.76)$ & 19.91(1.90) \\
\hline & PC1 & $-1.1(1.89)^{\mathrm{atm}}$ & $0.77(1.64)^{\mathrm{f}}$ & $0.59(0.88)^{\mathrm{f}}$ & $0.01(1.53)^{f}$ \\
\hline & $\mathrm{PC} 2$ & $0.08(1.35)^{\mathrm{a}}$ & $-0.20(1.01)^{\mathrm{a}}$ & $0.18(0.80)^{\mathrm{a}}$ & $0.11(1.12)$ \\
\hline \multirow{9}{*}{ 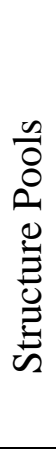 } & Depth $(\mathrm{cm})$ & $34.9(18.81)$ & $96.3(38.6)$ & 95 & $53.5(38.1)$ \\
\hline & Average velocity $(\mathrm{m} / \mathrm{s})$ & $0.15(0.11)$ & $0.03(0.02)$ & 0.1 & $0.09(0.12)$ \\
\hline & Fastest Velocity & $0.53(0.32)$ & $0.15(0.33)$ & 0.13 & $0.17(0.27)$ \\
\hline & $\Delta$ Velocity & $0.39(0.28)$ & $0.12(0.32)$ & 0.03 & $0.08(0.20) q$ \\
\hline & Distance to Cover (m) & $1.3(1.56)$ & $0.1(0.21)$ & 0 & $5.8(4.5)$ \\
\hline & Occupancy Ratio & $0.19(0.23)$ & $0.40(0.34)$ & 0.4 & -- \\
\hline & Temperature $\left({ }^{\circ} \mathrm{C}\right)$ & $19.78(2.39)$ & $19.08(1.52)$ & 18.91 & $19.49(1.95)$ \\
\hline & PC1 & $-1.96(1.87)^{\mathrm{ta}}$ & $0.72(1.99)^{\mathrm{f}}$ & $0.75(\mathrm{NA})$ & $0.16(1.61)^{f}$ \\
\hline & PC2 & $-0.86(0.50)$ & $-1.69(0.60)^{\mathrm{a}}$ & $-1.61(\mathrm{NA})$ & $0.11(1.20)$ \\
\hline \multirow{9}{*}{ 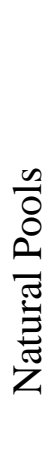 } & Depth $(\mathrm{cm})$ & $58.7(23.7)$ & $81.1(30.75)$ & 69.1(11.3) & $44.1(29.51)$ \\
\hline & Average velocity $(\mathrm{m} / \mathrm{s})$ & $0.11(0.12)$ & $0.10(0.08)$ & $0.10(0.09)$ & $0.12(0.14)$ \\
\hline & Fastest Velocity (m/s) & $0.23(0.21)$ & $0.17(0.14)$ & $0.15(0.11)$ & $0.21(0.23)$ \\
\hline & $\Delta$ Velocity & $0.12(18)$ & $0.07(0.08)$ & $0.05(0.05)$ & $0.09(0.16)$ \\
\hline & Distance to Cover (m) & $1.31(1.38)$ & $0.9(1.3)$ & $0.42(0.79)$ & $5.06(3.68)$ \\
\hline & Occupancy Ratio & $0.42(0.37)$ & $0.41(0.10)$ & $0.45(0.15)$ & -- \\
\hline & Temperature $\left({ }^{\circ} \mathrm{C}\right)$ & $19.63(1.64)$ & $20.63(2.16)$ & $20.29(1.79)$ & $20.17(1.85)$ \\
\hline & PC1 & $-0.16(1.33)$ & $0.41(1.01)$ & $0.75(0.73)$ & $-0.14(1.44)$ \\
\hline & PC2 & $-0.87(0.48)$ & $-1.26(0.61)^{\mathrm{a}}$ & $-1.61(0.24)^{\mathrm{a}}$ & $0.12(1.03)$ \\
\hline
\end{tabular}

${ }^{a}$ Letters denote statistical difference between group and available habitat ( $\mathrm{p}<0.05$, avalysis of variance, Tukey post hoc comparisons) ${ }^{t}$ Letters denote statistical difference between group and brown trout use ( $\mathrm{p}<0.05$, avalysis of variance, Tukey post hoc comparisons)

${ }^{\mathrm{m}}$ Letters denote statistical difference between group and rainbow trout use ( $\mathrm{p}<0.05$, avalysis of variance, Tukey post hoc comparisons)

${ }^{\mathrm{f}}$ Letters denote statistical difference between group and brook trout use ( $\mathrm{p}<0.05$, avalysis of variance, Tukey post hoc comparisons) 
Table 2: Results for principal components analysis for trout habitat use. Eigenvalues, percent variation explained, and factor loadings are shown for the first two axes. -indicate factor loadings of $<|0.4|$.

\begin{tabular}{lcc}
\hline Variable & PC1 & PC2 \\
\hline Eigenvalue & 2.37 & 1.27 \\
\% variation & 47.7 & 25.9 \\
Depth $(\mathrm{m})$ & -- & -0.61 \\
Average velocity $(\mathrm{m} / \mathrm{s})$ & -0.48 & -- \\
Fastest velocity $(\mathrm{m} / \mathrm{s})$ & -0.63 & -- \\
$\Delta$ Velocity $(\mathrm{m} / \mathrm{s})$ & -0.53 & -- \\
Distance to cover $(\mathrm{m})$ & -- & 0.76 \\
\hline
\end{tabular}




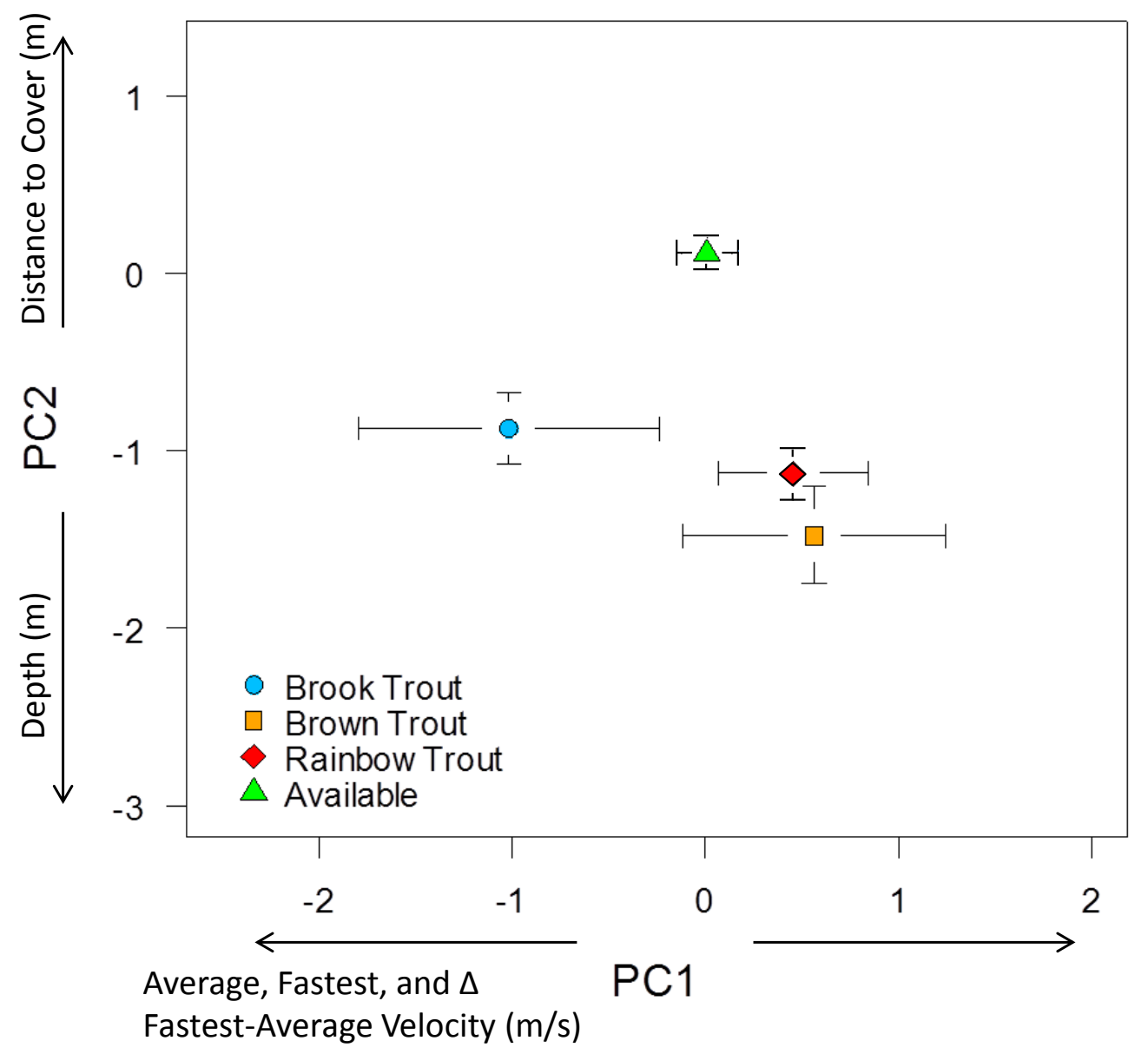

Figure 2: Mean and 95\% confidence intervals of PC1 and PC2 scores brook trout, brown trout, and rainbow trout habitat use across all pool types. Labels and arrows on axes indicates corresponding trends in habitat characteristics. 


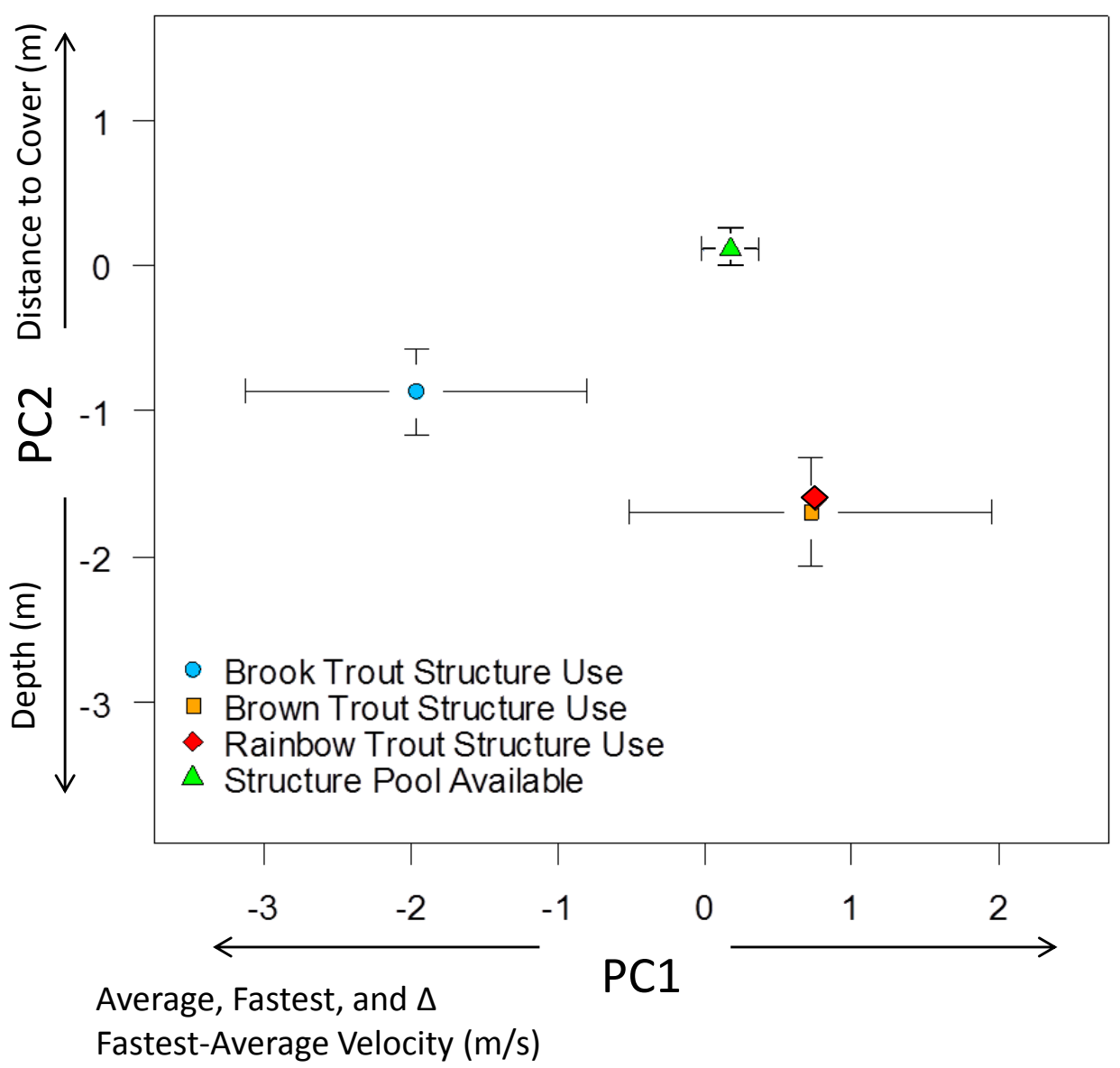

Figure 3: Mean and 95\% confidence intervals of trout habitat use and availability within structure pools for PC1 and PC2. Labels and arrows on axes indicates corresponding trends in habitat characteristics. 


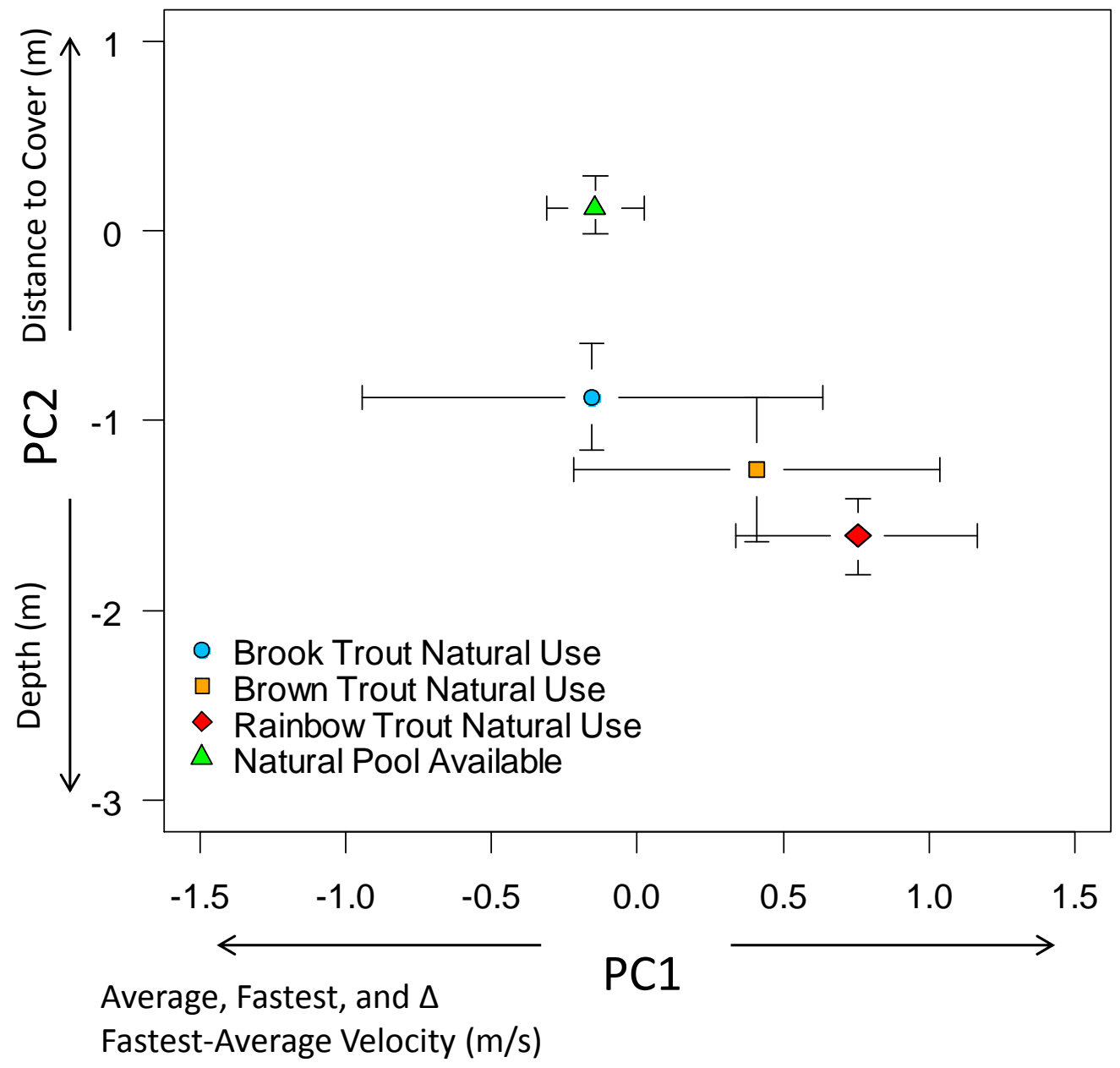

Figure 4: Mean and 95\% confidence intervals of trout habitat use and availability within natural pools for PC1 and PC2. Labels and arrows on axes indicates corresponding trends in habitat characteristics. 


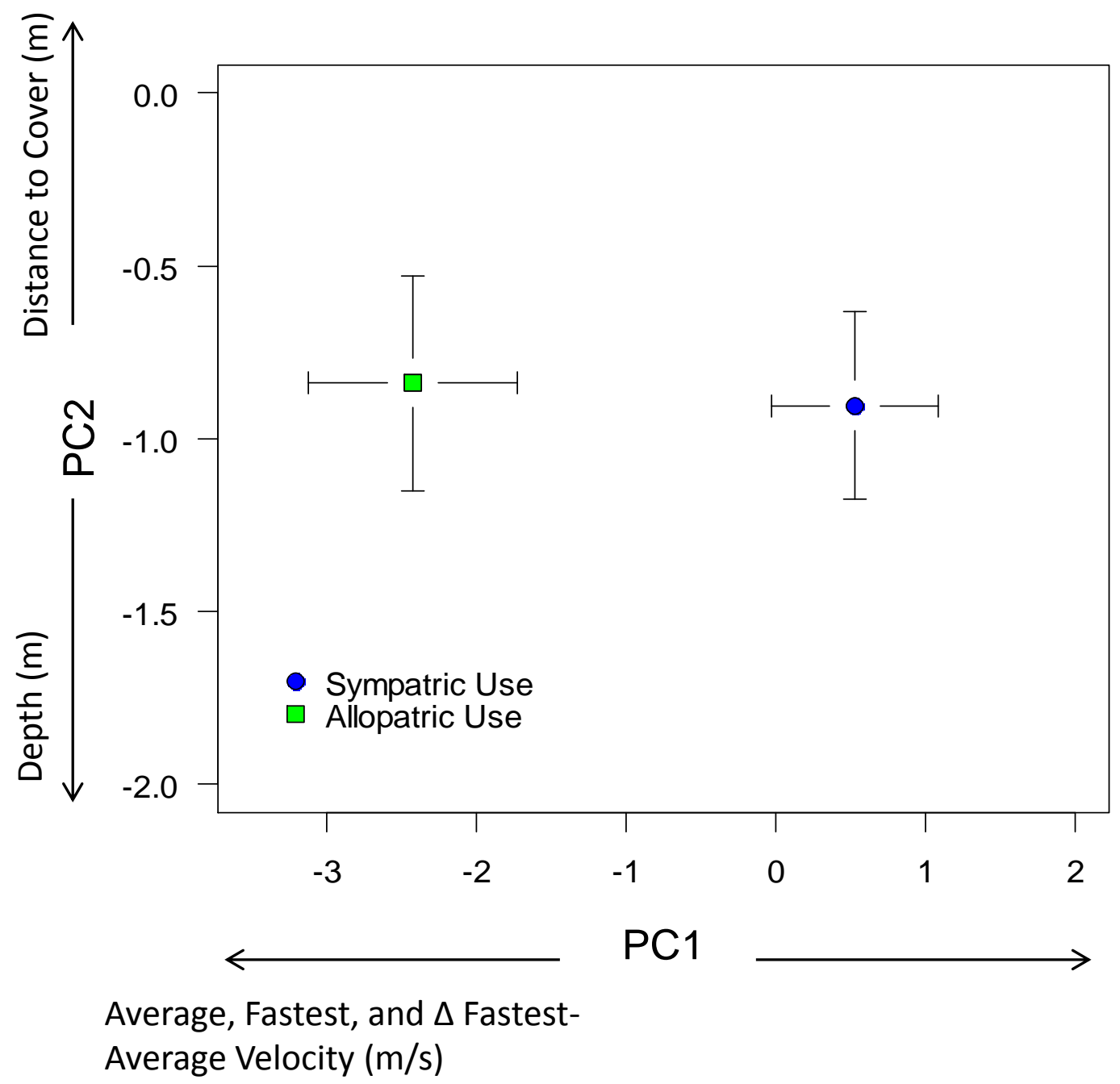

Figure 5: Mean and 95\% confidence intervals of trout habitat use and availability within natural pools for PC1 and PC2. Labels and arrows on axes indicates corresponding trends in habitat characteristics. 


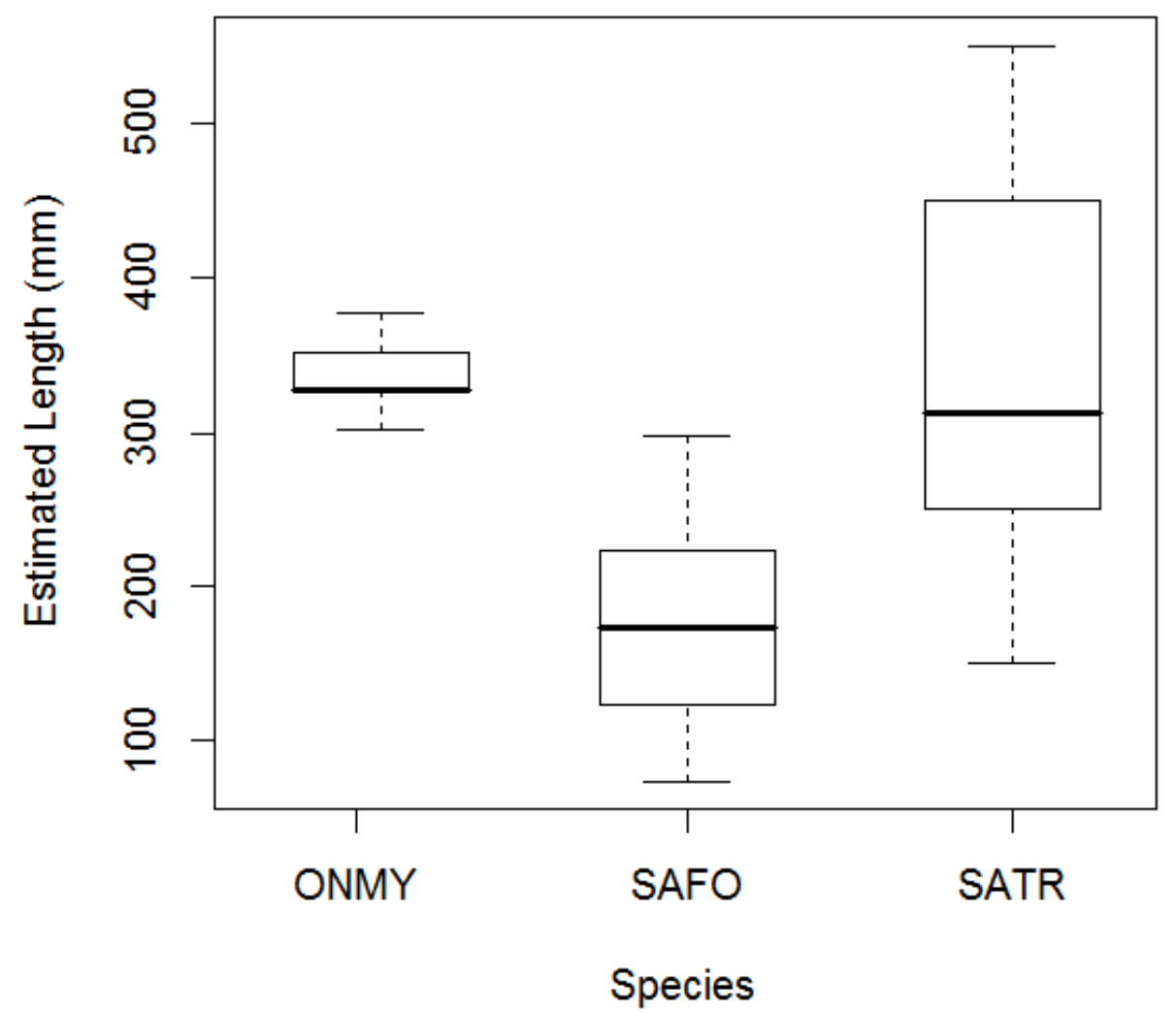

Figure 6: Boxplot comparing length distributions across species. Brown and rainbow trout exhibited significantly greater lengths than native brook trout, but did not differ significantly from each other. 
Table 3: Parameter estimates for the minimum adequate model relating PC scores to trout species and length. Estimates shown are the intercept for the species listed and the slope for length in additive models.

\begin{tabular}{|c|c|c|c|c|}
\hline Analysis & Response Variable & Model Type & Parameter & Estimate \\
\hline \multirow{8}{*}{$\begin{array}{l}\frac{\infty}{0} \\
0 \\
0 \\
\\
\end{array}$} & \multirow{4}{*}{ PC1 } & \multirow{4}{*}{ Additive } & Rainbow & -1.923 \\
\hline & & & Brown & -1.915 \\
\hline & & & Brook & -2.291 \\
\hline & & & Length & 0.007 \\
\hline & \multirow{4}{*}{ PC2 } & \multirow{4}{*}{ Additive } & Rainhow & 0070 \\
\hline & & & Nantor & -0.013 \\
\hline & & & Brook & -0.308 \\
\hline & & & Length & -0.003 \\
\hline \multirow{8}{*}{ 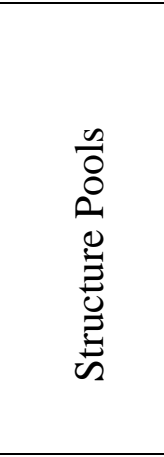 } & \multirow{4}{*}{ PC1 } & \multirow{4}{*}{ Additive } & Rainbow & -1.941 \\
\hline & & & Brown & -2.149 \\
\hline & & & Brook & -2.344 \\
\hline & & & Length & 0.007 \\
\hline & \multirow{4}{*}{ PC2 } & \multirow{4}{*}{ Additive } & Rainbow & -0.040 \\
\hline & & & Brown & -0.311 \\
\hline & & & Brook & -0.264 \\
\hline & & & Length & -0.003 \\
\hline \multirow{5}{*}{ 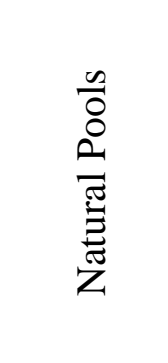 } & \multirow{5}{*}{ PC2 } & \multirow[b]{2}{*}{ Common } & Brown & 1.734 \\
\hline & & & Brook & 2.966 \\
\hline & & \multirow{3}{*}{ Additive } & Brown & -0.527 \\
\hline & & & Brook & -0.396 \\
\hline & & & Length & -0.003 \\
\hline \multirow{5}{*}{ 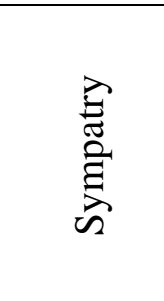 } & & & Allopatric & -2.421 \\
\hline & PC1 & Common & Sympatric & 0.525 \\
\hline & & & Allopatric & -0.292 \\
\hline & PC2 & Additive & Sympatric & -0.150 \\
\hline & & & Length & -0.004 \\
\hline
\end{tabular}




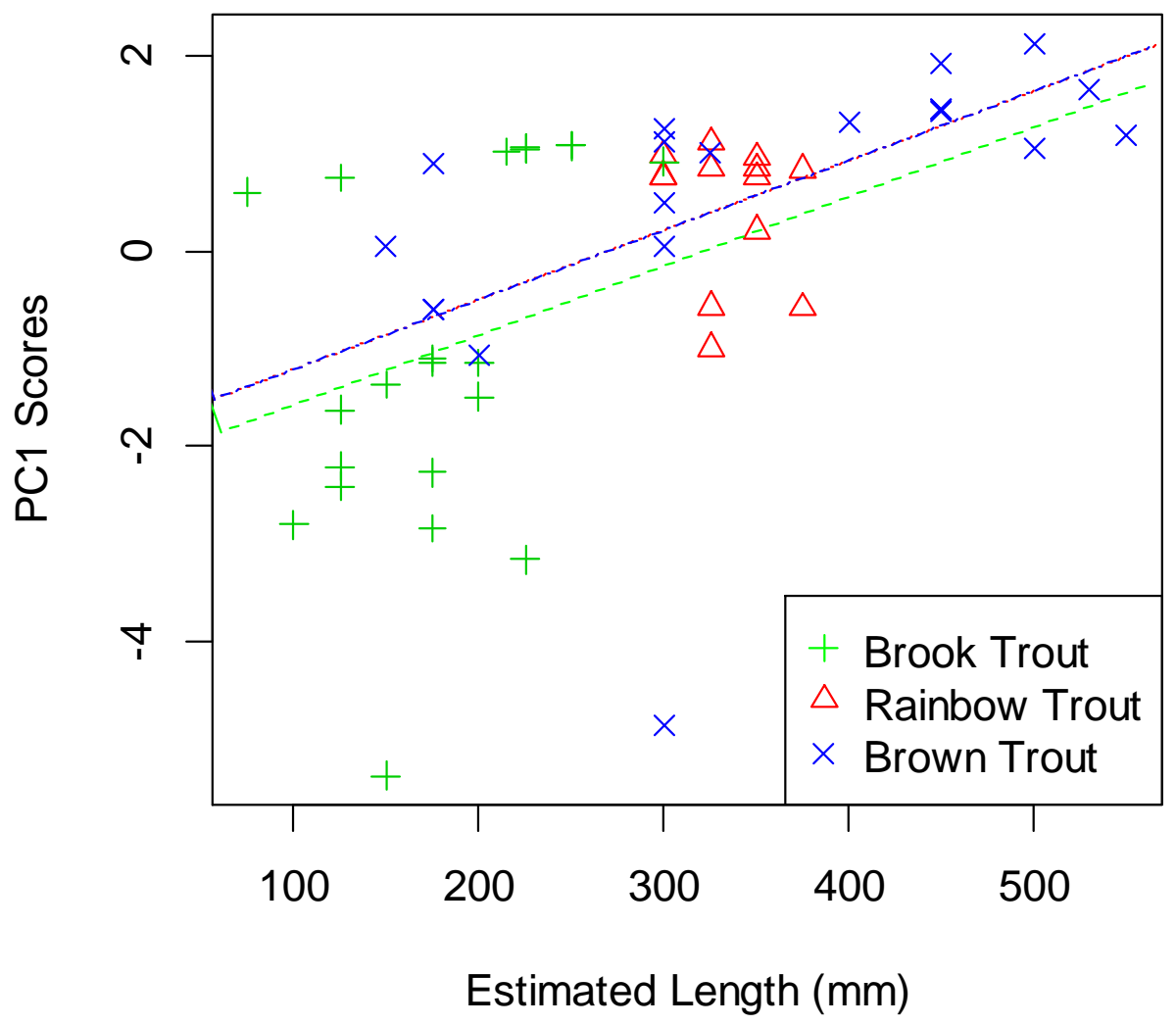

Figure 7: Regression between brook, brown, and rainbow trout comparing estimated length to PC1 scores. Intercepts were allowed to vary (but sloped remained constant) in this additive model, but only length significantly influenced PC1 scores across all pools. Brown and rainbow trout had nearly identical intercepts, while brook trout had an intercept slightly lower than both nonnative species. 


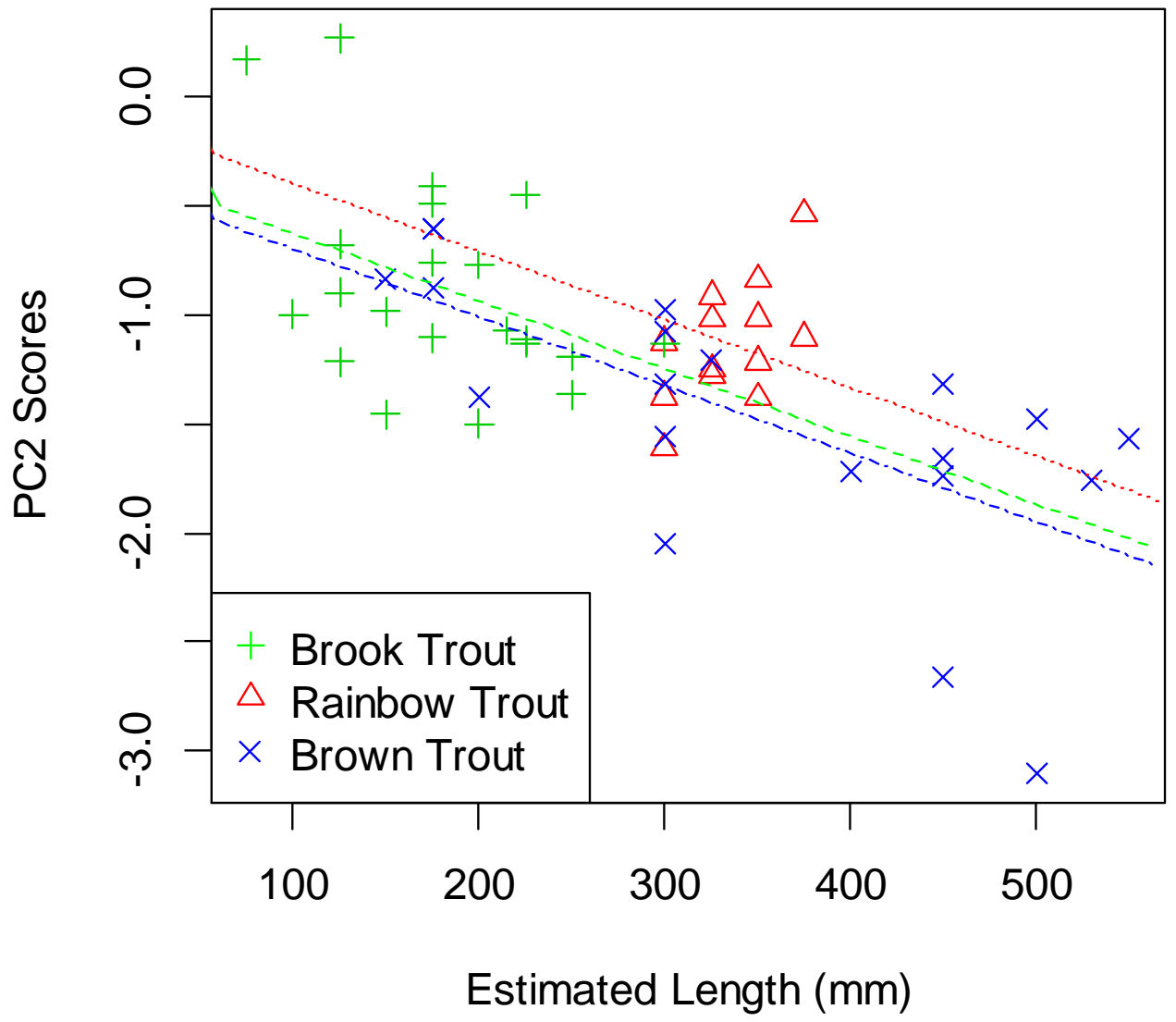

Figure 8: Regression between brook, brown, and rainbow trout comparing estimated length to PC2 scores across all pools. Intercepts were allowed to vary in this additive model, but only length significantly influenced PC2 scores. Rainbow trout had a higher intercept than brook and brown trout, respectively. 


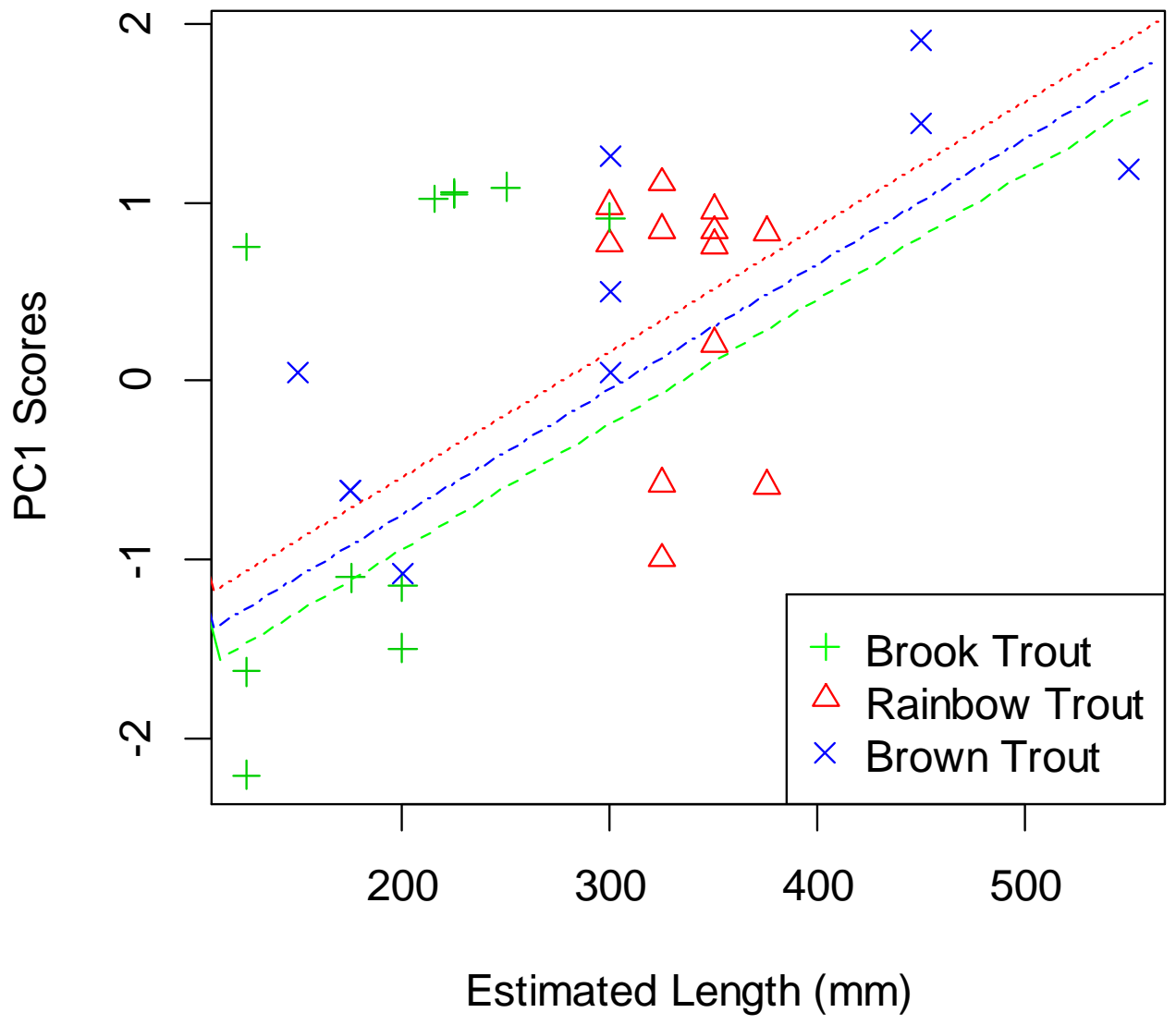

Figure 9: Regression between brook, brown, and rainbow trout comparing estimated length to PC1 scores in natural pools. Intercepts were allowed to vary in this additive model, but only length significantly influenced PC1 scores. Rainbow trout had the highest intercept, followed by brown and then brook trout, respectively. 


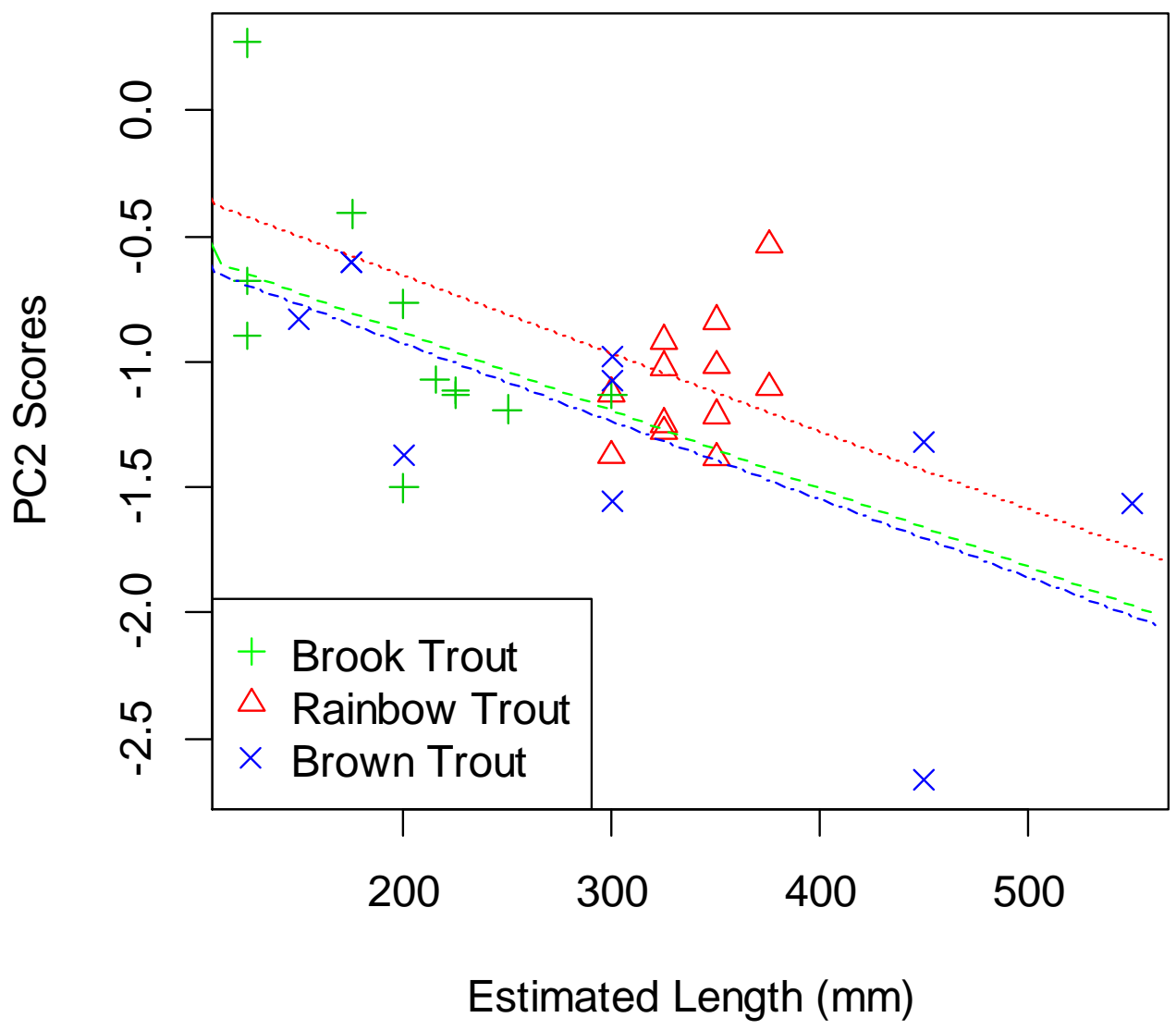

Figure 10: Regression between brook, brown, and rainbow trout comparing estimated length to PC2 scores in natural pools. Intercepts were allowed to vary in this additive model, but only length significantly influenced PC1 scores. Brown and brook trout had similar intercepts, while rainbow trout had an intercept slightly higher. 


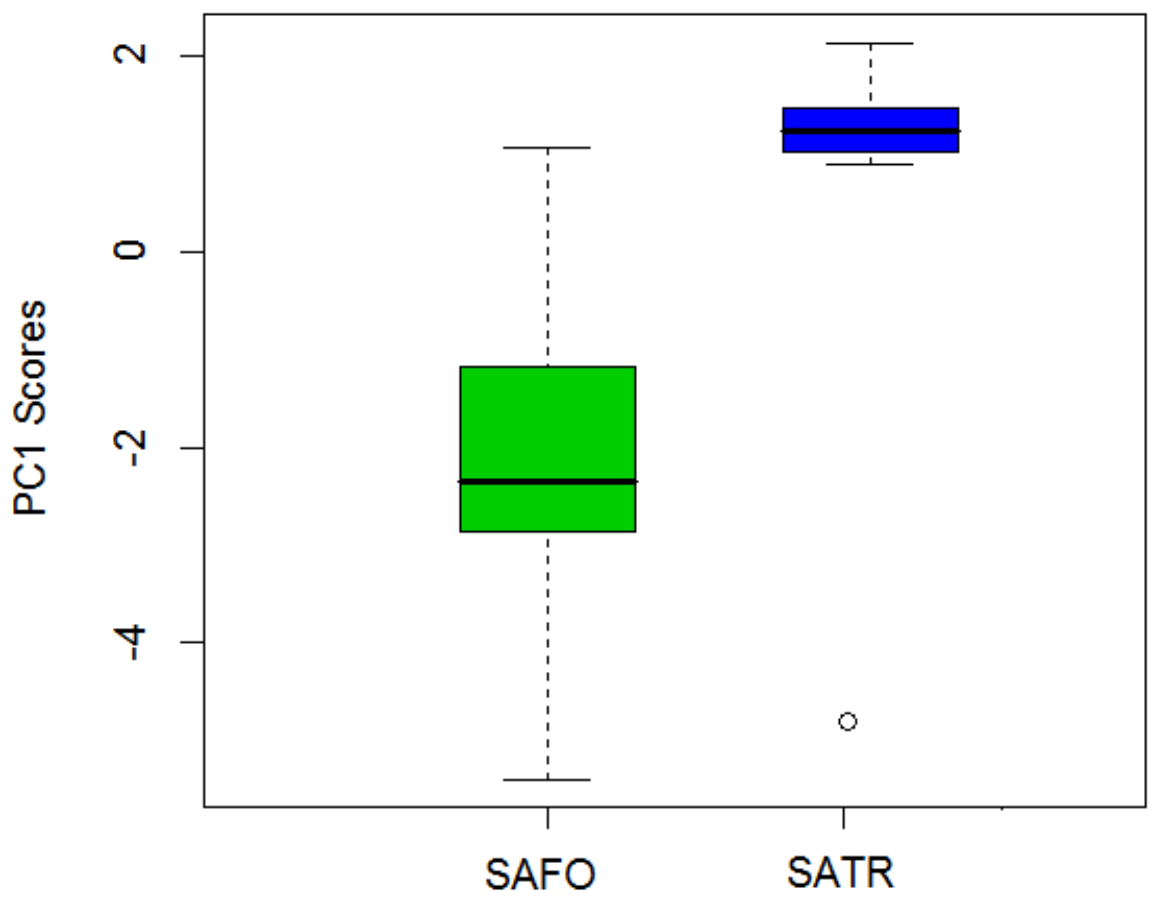

Species

Figure 11: Comparison of the distribution of PC1 score for brook (SAFO) and brown (SATR) trout in structure pools. Brown trout occupied habitat with higher PC1 scores, indicating that they were selecting for slower velocity habitat within these pools. 


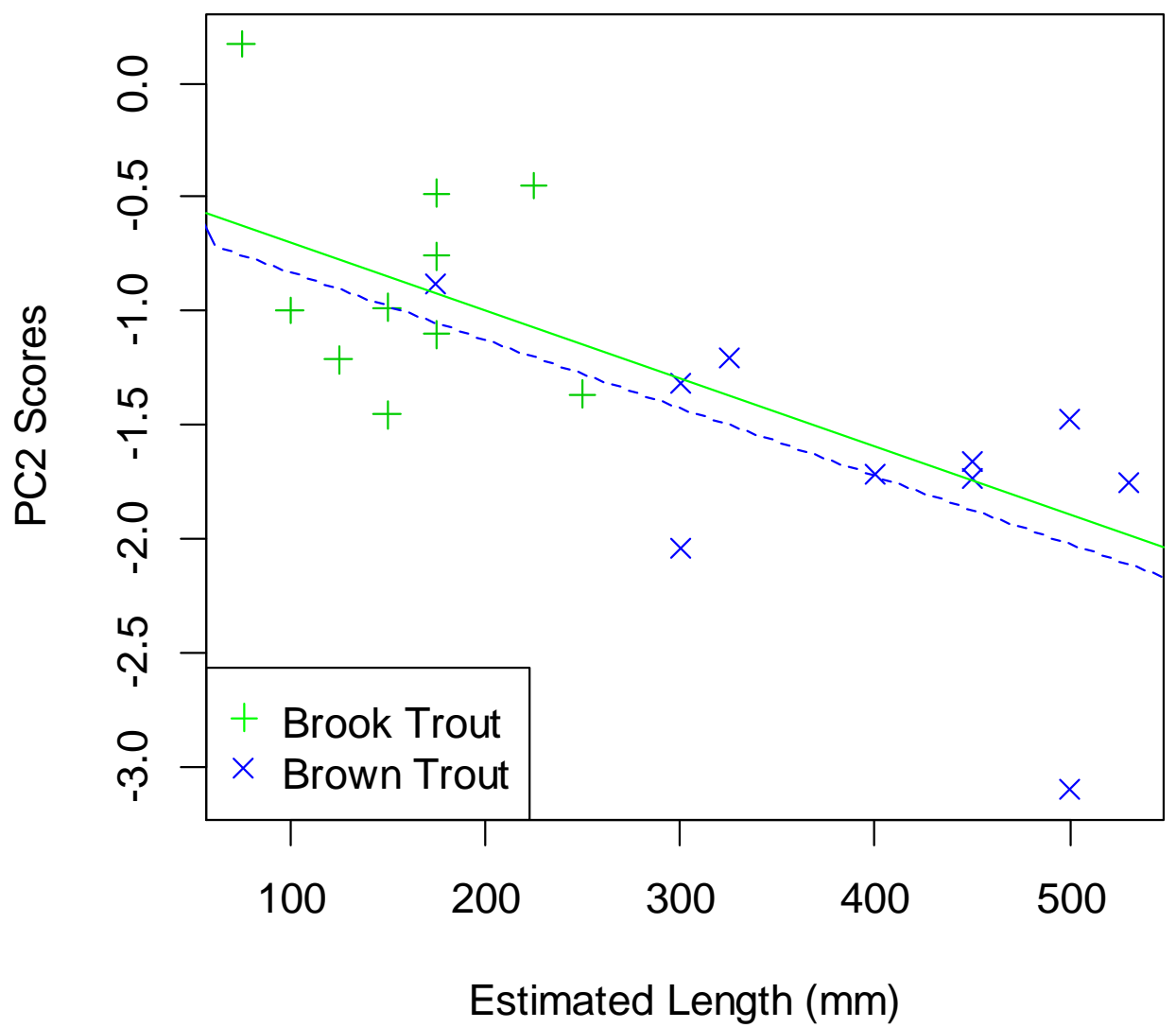

Figure 12: Regression between brook and brown trout comparing estimated length to PC2 scores. Intercepts were allowed to vary, but only length significantly influenced PC1 scores. 


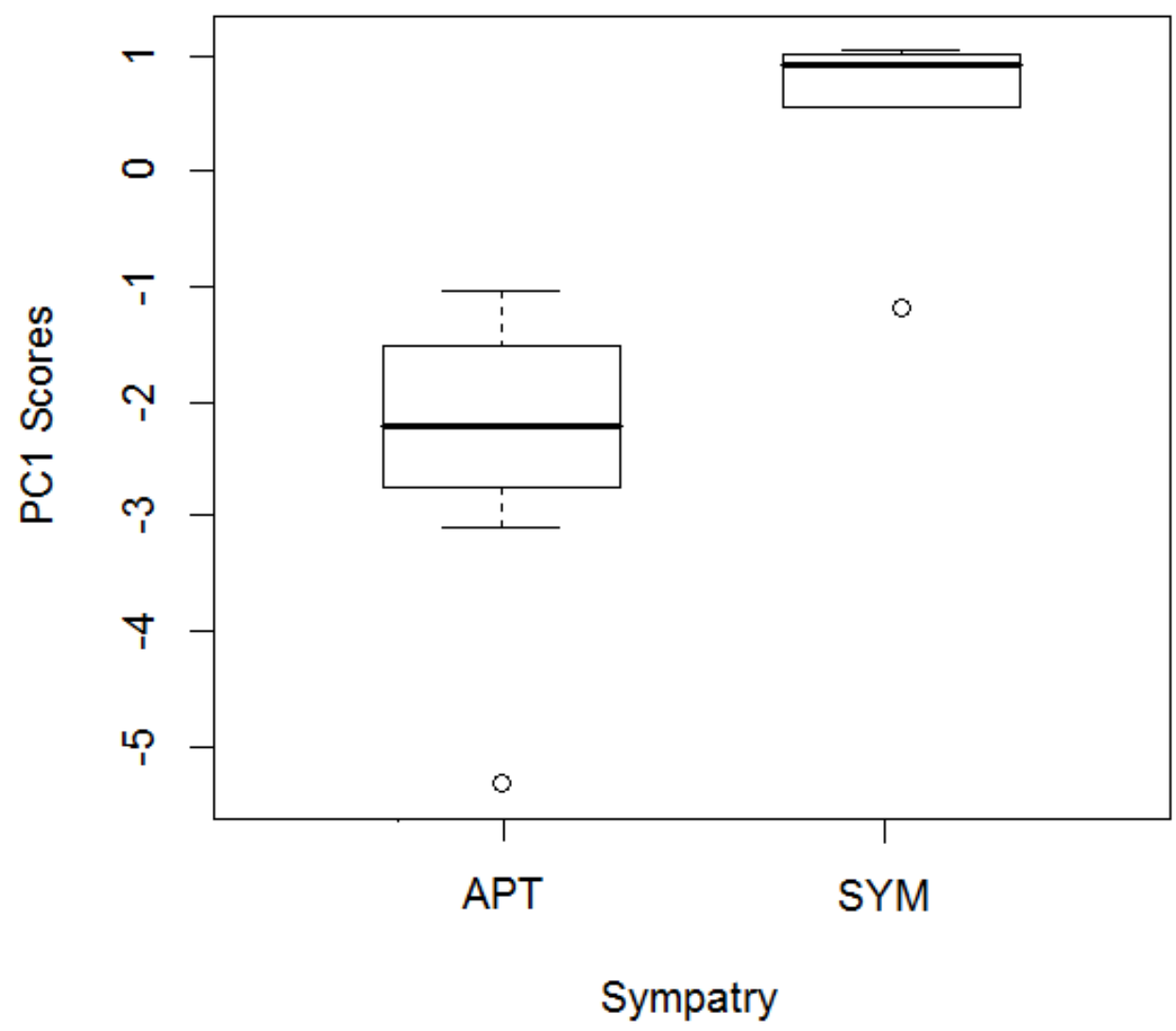

Figure 13: Distribution of PC1 scores of brook trout occupying pools sympatrically with brown trout (SYM) and brook trout occupying pools allopatrically (APT). Sympatric brook trout tended to be larger than allopatric brook trout, but this difference was not significant at the $\alpha=0.05$ level. 


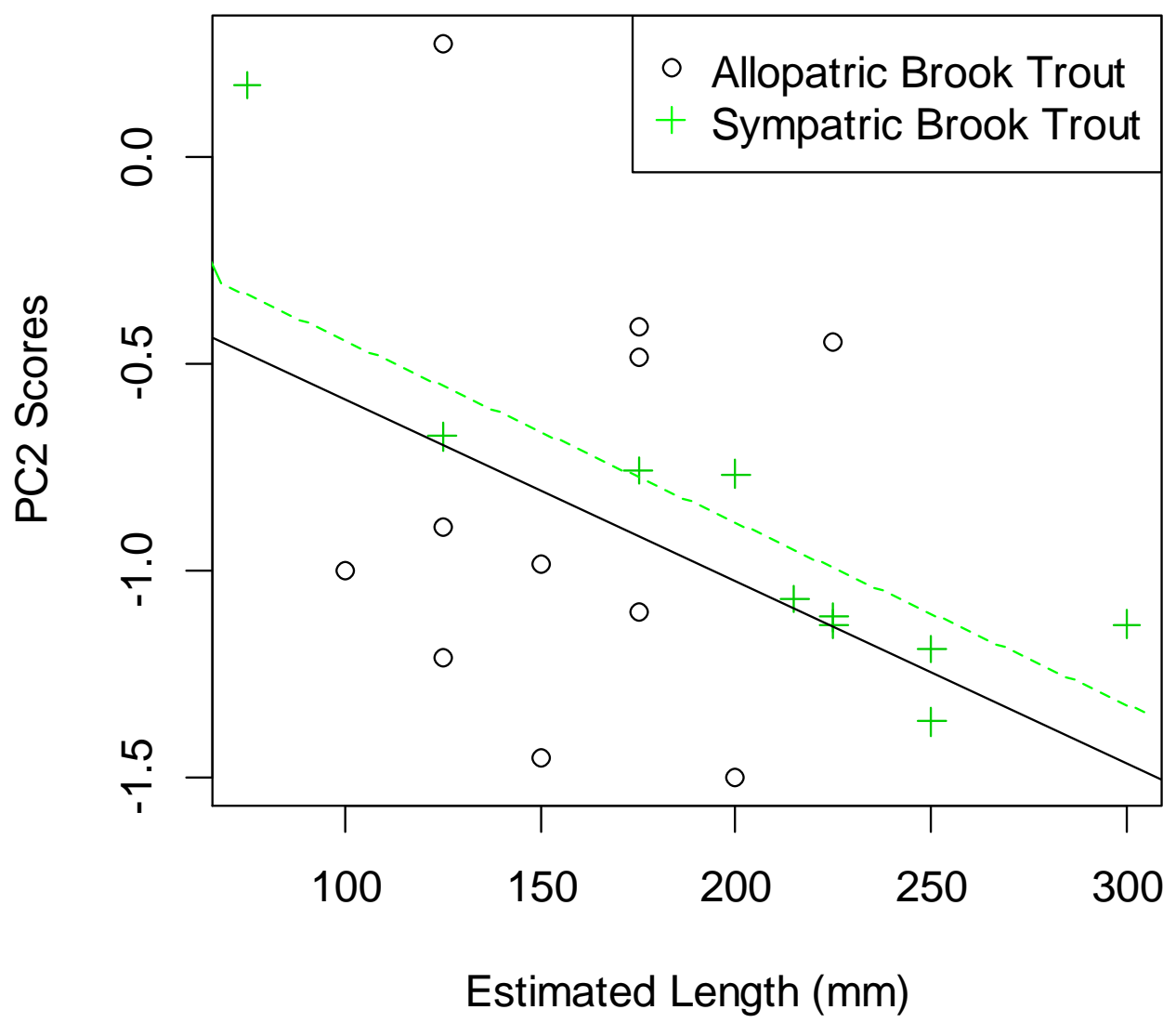

Figure 14: Regression comparing the length of sympatric and allopatric brook trout on PC2 scores. Length significantly influenced PC2 scores, where larger trout occupied habitat deeper and closer to cover than smaller brook trout, but sympatry did not have a significant effect. 


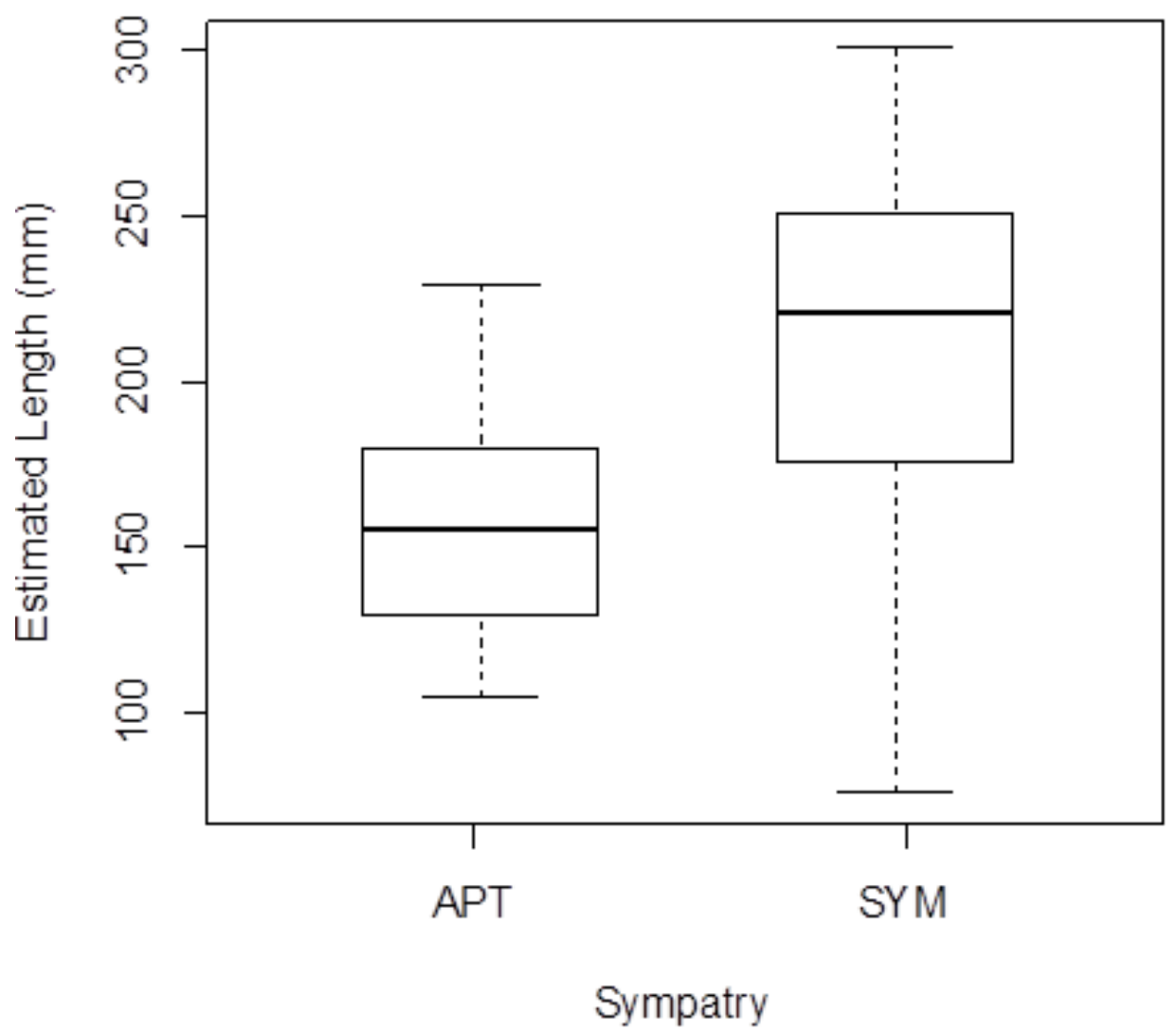

Figure 15: Distribution of estimated brook trout length for trout occupying pools sympatrically with brown or rainbow trout (SYM) and occupying pools allopatrically (APT). Sympatric brook trout tended to be larger than allopatric brook trout, but this difference was not significant at the $\alpha=0.05$ level. 


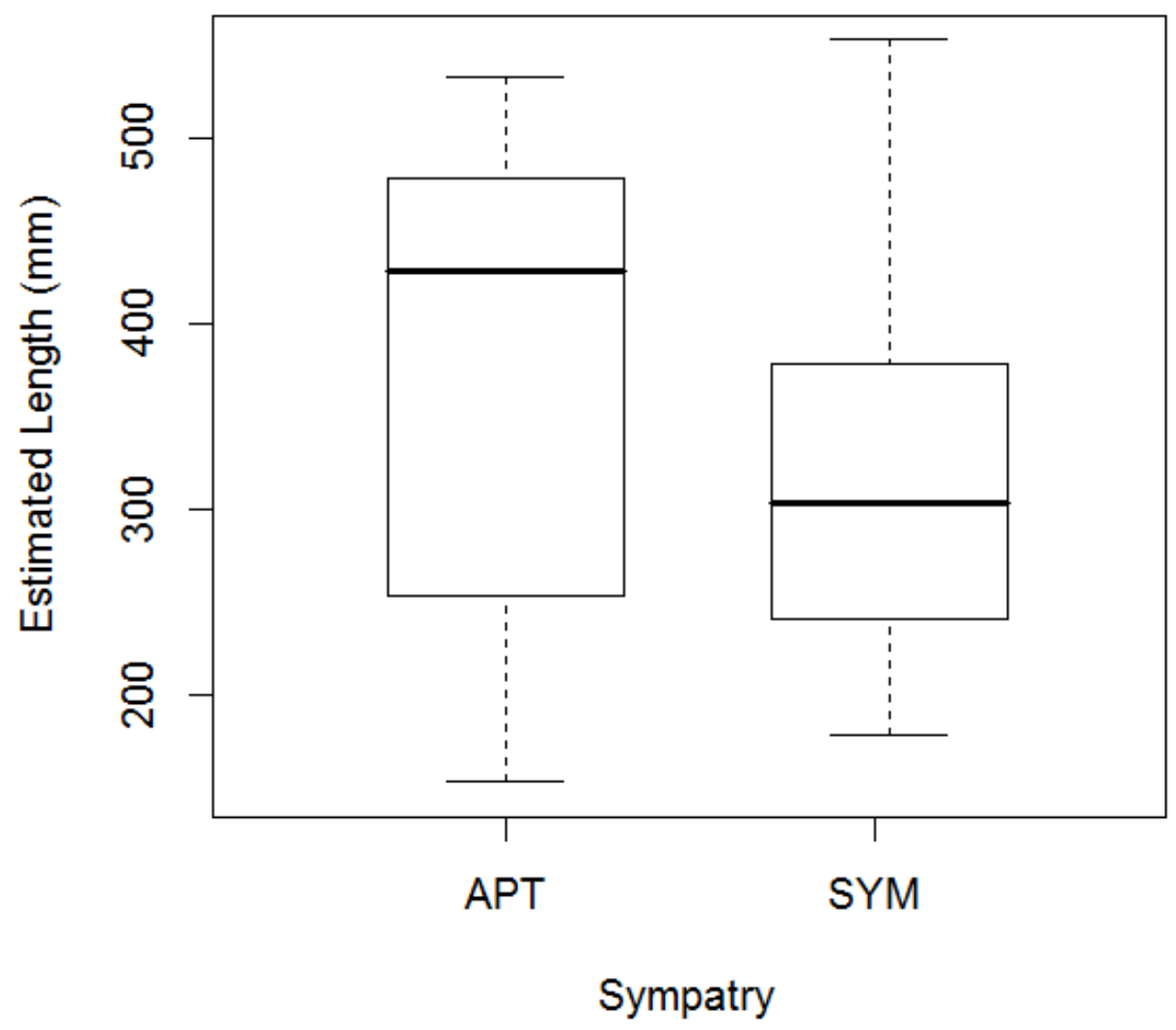

Figure 16: Comparison of the distribution of estimated brown trout length with trout occupying pools sympatrically with brook trout (SYM) and trout occupying pools allopatrically (APT). Sympatric brown trout tended to be smaller than allopatric brown trout, but this difference was not significant at the $\alpha=0.05$ level. 